\author{
University of Szeged \\ Faculty of Pharmacy \\ Graduate School of Pharmaceutical Sciences \\ Department of Pharmacognosy
}

Ph.D. Thesis

\title{
Isolation and Structure Elucidation of Diterpenes from Euphorbia pannonica, E. esula and E. falcata
}

Edvárd István Sulyok Pharm.D.

Supervisors:

Prof. Judit Hohmann DSc.

Andrea Vasas PhD.

Szeged, Hungary 


\section{LIST OF PUBLICATIONS RELATED TO THE THESIS}

I. Sulyok E; Vasas A; Rédei D; Dombi G; Hohmann J.

Isolation and structure determination of new 4,12-dideoxyphorbol esters from Euphorbia pannonica Host.

Tetrahedron 2009; 65: 4013-4016.

II. Vasas A; Sulyok E; Rédei D; Forgo P; Szabó P; Zupkó I; Berényi A; Molnár J; Hohmann J. Jatrophane diterpenes from Euphorbia esula as antiproliferative agents and potent chemosensitizers to overcome multidrug resistance J. Nat. Prod. 2011; 74: 1453-1461.

III. Sulyok E; Vasas A; Rédei D; Forgo P; Kele Z; Pinke G; Hohmann J. New premyrsinane-type diterpene polyesters from Euphorbia falcata Tetrahedron 2011; 67: 7289-7293.

IV. Vasas A; Sulyok E; Martins A; Rédei D; Forgo P; Kele Z; Zupkó I; Molnár J; Pinke G; Hohmann J. Cyclomyrsinane and premyrsinane diterpenes from Euphorbia falcata modulate resistance of cancer cells to doxorubicin Tetrahedron 2012; 68: 1280-1285. 


\section{TABLE OF CONTENTS}

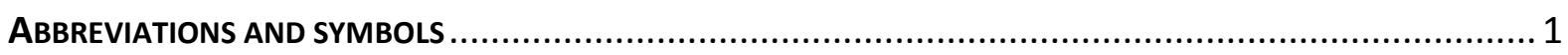

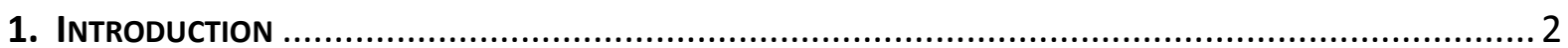

1.1. Botany of the family Euphorbiaceae and the investigated Euphorbia species ............. 3

1.2. Chemical constituents of the family Euphorbiaceae................................................... 4

1.2.1. Diterpenoids of the family Euphorbiaceae ............................................................. 5

1.2.2. Chemical constituents of Euphorbia pannonica ................................................. 8

1.2.3. Chemical constituents of Euphorbia esula .............................................................. 8

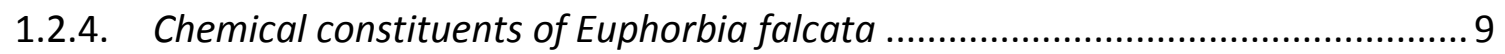

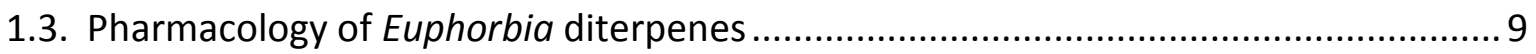

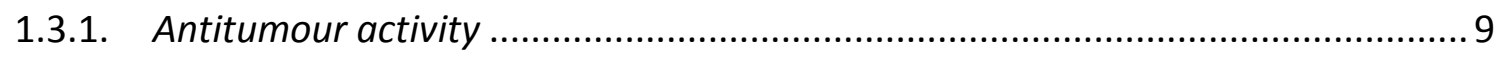

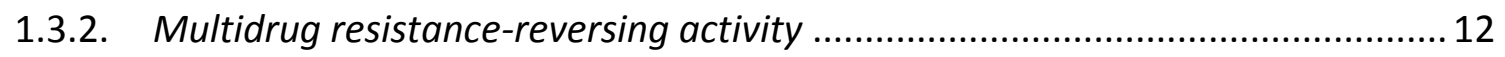

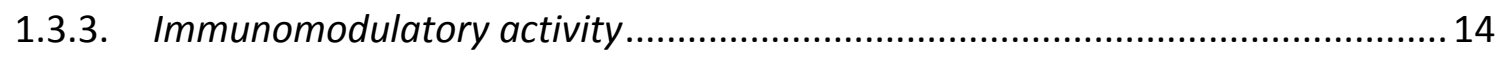

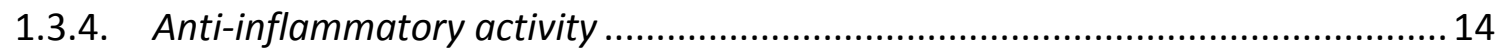

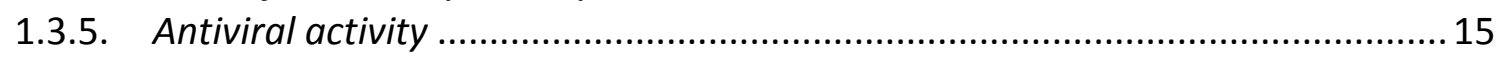

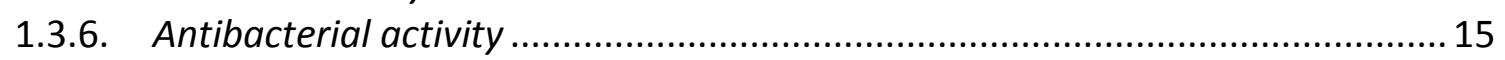

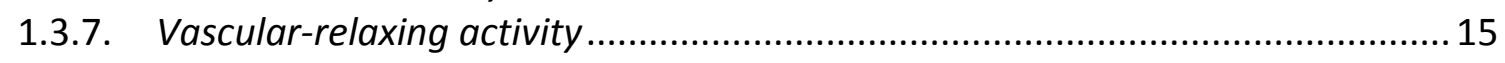

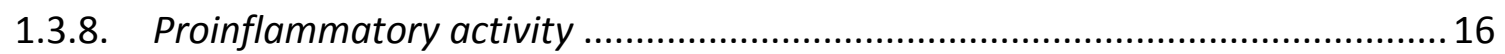

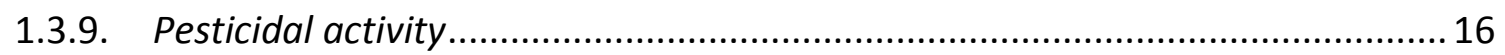

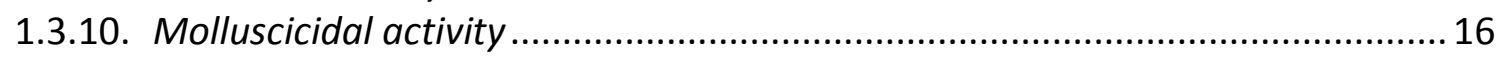

1.4. Folk-medicinal use of the investigated Euphorbia species .................................... 17

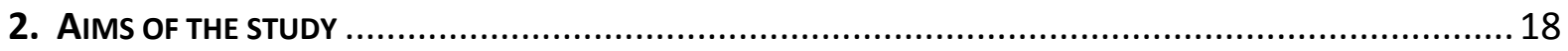

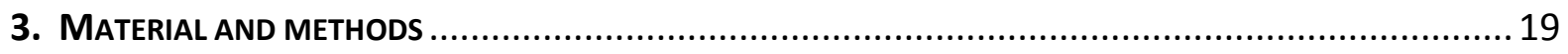

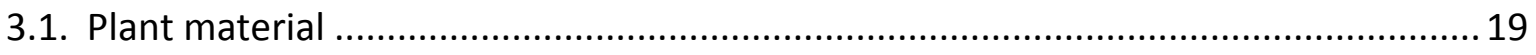

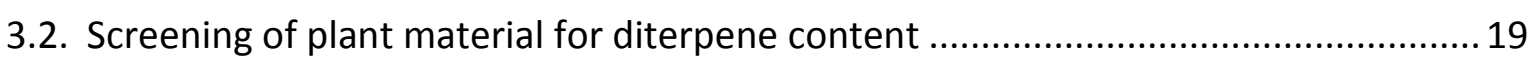

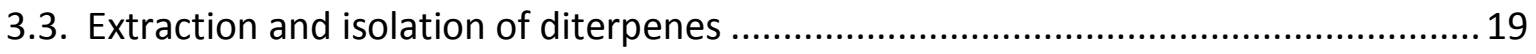

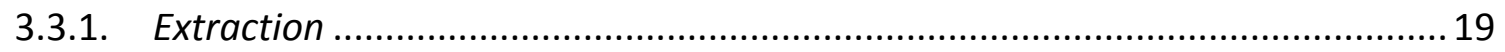

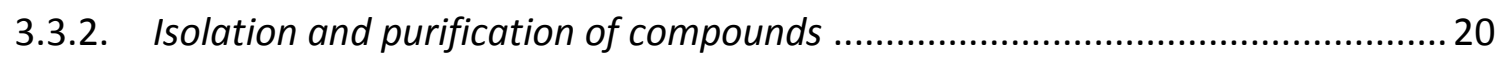

3.4. Characterization and structure determination of the isolated compounds ............... 21

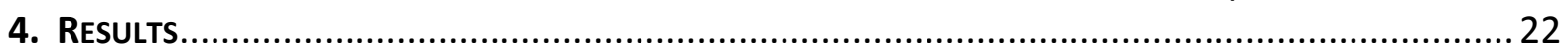

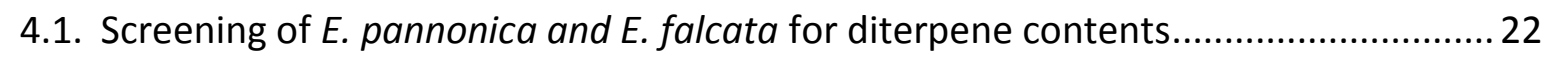

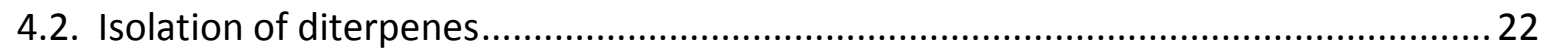

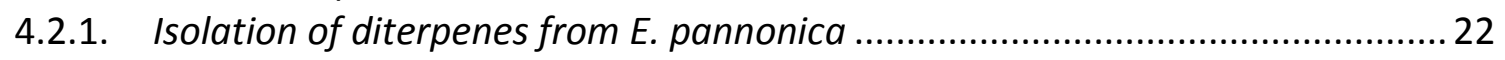

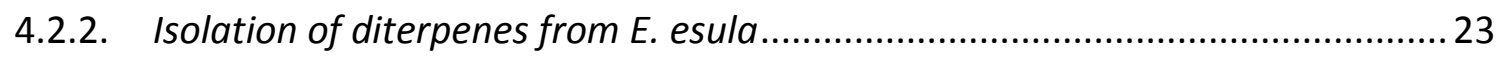

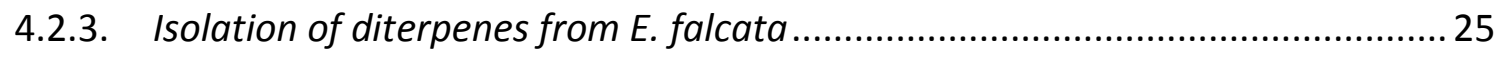

4.3. Characterization and structure determination of the isolated compounds ................ 28

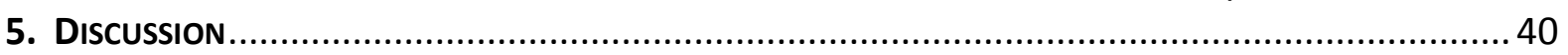

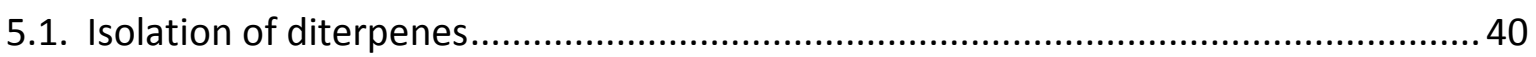

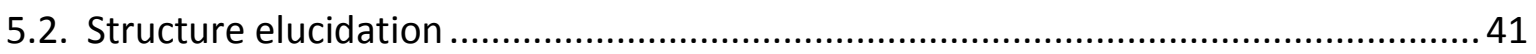

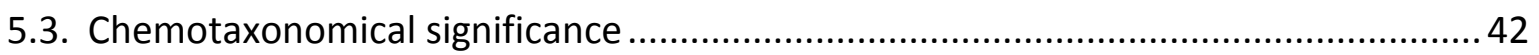

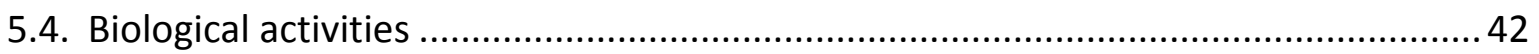

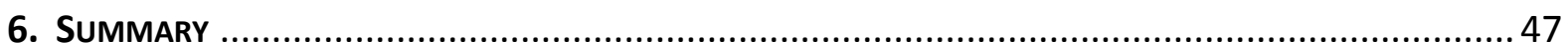

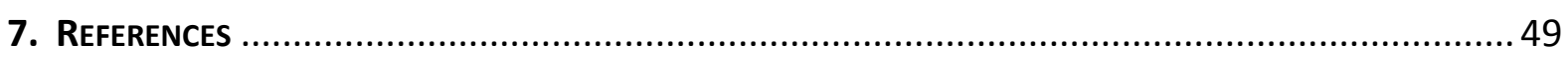

ACKNOWLEDGEMENTS

APPENDIX 


\section{AbBreViations AND SYMBols}

$1 \mathrm{D}$

2D

COSY

cryst

$\delta$

ESIMS

$\mathrm{fr}$

HMBC

HSQC

HPLC

HRE(S)IMS

IR

JMOD

MDR

NMR

MS

NOE

NOESY

NP

OCC

P-gp

PKC

PLC

$\mathrm{RP}$

RPC

TLC

$t_{\mathrm{R}}$

UV

VLC

Ester groups: one-dimensional

two-dimensional

correlated spectroscopy

crystallization

chemical shift

electronspray ionization mass spectroscopy

fraction

heteronuclear multiple-bond correlation spectroscopy

heteronuclear single-quantum coherence spectroscopy

high-performance liquid chromatography

high-resolution electron (spray) ionization mass spectroscopy

infrared

$J$-modulated spin-echo experiment

multidrug resistance

nuclear magnetic resonance

mass spectroscopy

nuclear Overhauser effect

nuclear Overhauser enhancement spectroscopy

normal-phase

open-column chromatography

permeability glycoprotein

protein kinase $\mathrm{C}$

preparative-layer chromatography

reversed-phase

rotation planar chromatography

thin-layer chromatography

retention time

ultraviolet

vacuum-liquid chromatography

$\mathrm{Ac}=$ acetyl, $\mathrm{Bz}=$ benzoyl, $\mathrm{Nic}=$ nicotinoyl, Prop $=$ propanoyl,$i \mathrm{Bu}=$ isobutanoyl $\mathrm{MeBu}=2$-methylbutanoyl, $i \mathrm{Val}=$ isovaleroyl, Hex = hexanoyl 


\section{INTRODUCTION}

The family Euphorbiaceae is one of the largest families of flowering plants, composed of 5 subfamilies, 49 tribes, over 300 genera and about 8000 species. ${ }^{1}$ The genus Euphorbia is one of the 6 largest genera (Astragalus, Bulbophyllum, Psychotria, Euphorbia, Carex and Begonia) of flowering plants, with approximately 1830 species. $^{2}$ The Euphorbia are widely distributed throughout both hemispheres and range in morphology from large desert succulents to trees, through climbing lianas and even some small herbaceous plant types. ${ }^{3} 28$ species of this genus have been found in Hungary. ${ }^{4}$ The researched parts in various Euphorbia species include the roots, seeds, latex, lactiferous tubes, stem wood, stem bark, leaves and whole plants.

Many Euphorbiaceae species are characterized by the occurrence of a highly irritant milky latex. These plants have been used to treat different cancers, tumours and warts since at least the time of HIPPOCRATES. ${ }^{5}$ The folk-medicinal uses of Euphorbia species include the treatment of infections, gonorrhoea, migraine, intestinal parasites, rheumatism, snake-bites, asthma, obstipation, coughs, sores and skin diseases. ${ }^{6}$ The family consists of species of great economic importance, such as Ricinus communis L. (castor oil), Croton tiglium (croton oil), Manihot esculenta Crantz (cassava, tapioca), Hevea brasiliensis Willd. ex. A. Juss (rubber tree), Euphorbia tetragonal and E. triangularis (inferior rubber), and Euphorbia resinifera ('euphorbium'). ${ }^{7-9}$ Moreover, it includes noxious weeds such as Euphorbia esula L. and Euphorbia maculata L. Five species, E. pekinensis, E. kansui, E. lathyris, E. humifusa and E. maculata, have been recorded in Chinese pharmacopoeias for the treatment of oedema, gonorrhoea, migraine and wart cures, whereas these are well-known poisonous plants. ${ }^{10}$

Diterpenes occurring in plants of the Euphorbiaceae family are of considerable interest from the aspect of natural product drug discovery because of the wide range of their potentially valuable biological activities and their broad structural diversity resulting from the variable acylation of many different skeletons (e.g. ingenane, tigliane, daphnane, lathyrane and jatrophane) with numerous aliphatic and aromatic acids. The importance of Euphorbiaceae diterpenes may be demonstrated primarily by the approval granted by the FDA in 2012 for the use of ingenol 3-angelate (ingenol mebutate, PEP005, Picato ${ }^{\circledR}$, LEO Pharma) in the treatment of actinic keratosis, a precancerous skin condition. Besides ingenol 3-angelate, other promising compounds are currently subjects of drug development projects. Some phorbol and ingenol derivatives, and particularly prostratin, have become of considerable interest in HIV therapy: they reactivate HIV-1 latency by protein kinase C (PKC)-dependent NF-KB (nuclear factor) activation, and avoid the new infection of $\mathrm{CD}^{+}{ }^{+}$cells. ${ }^{11}$ Resiniferatoxin, a compound belonging in the daphnane group, is an ultrapotent capsaicin analogue, which is at present undergoing evaluation in phase II and III clinical trials. ${ }^{12}$ Moreover, antileukaemic 
ingenane diterpenes have been obtained from Euphorbia esula, Croton tiglium and Cunuria spruceana. Further interesting diterpene esters with great structural variety and noteworthy biological activities have been isolated from Euphorbiaceae species. ${ }^{13-21}$

In 1995, the workgroup of Department of Pharmacognosy, University of Szeged initiated a research programme with the aim of investigating the secondary metabolites of Hungarian Euphorbia species. In the course of these studies, many diterpene esters of different skeletal types have been isolated. ${ }^{22-33}$ One part of this programme involved the investigation of Euphorbia pannonica Host., E. esula L. and E. falcata L. The present thesis summarizes the results of these phytochemical works.

\subsection{Botany of the family Euphorbiaceae and the investigated Euphorbia species}

The Euphorbiaceae comprise one of the largest and most diversified families of angiosperms and, because of the range of morphological variation, may be polyphyletic in origin. There is great diversity in growth form, ranging from tall rain forest trees to lianas, shrubs, perennial and annual herbs, geophytes, succulents and floating aquatics. ${ }^{3}$ The tribe Euphorbieae is characterized by the possession of a unique cyathium, which consists of a central carpellate flower and 4 or 5 groups of basal male-flower clusters. Euphorbia plants are monoecious. ${ }^{34,35}$

The investigated plants, Euphorbia pannonica, E. esula and E. falcata, belong in the section Tithymalus of the genus Euphorbia in the family Euphorbiaceae, in the order Euphorbiales.

Euphorbia pannonica Host. (syn. Euphorbia nicaeensis All., E. goldei Prokh., E. stepposa Zoz ex Prokh., E. volgensis Krysht.) is a glabrous or minutely papillose, glaucous, often reddish-suffused perennial plant, up to $80 \mathrm{~cm}$ in height. It has $0-10(-20)$ axillary rays. The leaves, measuring $10-$ $75 \times 3-18 \mathrm{~mm}$, are lanceolate to oblong or occasionally ovate, nearly entire, obtuse, coriaceous, and $3(-7)$-veined. The ray-leaves are elliptic-ovate to suborbicular; the raylet-leaves are transversely ovate or reniform and often yellowish. The rays number (3-)5-18, and are once or twice dichotomous. The glands are truncate to emarginated or sometimes display 2 short horns. The capsule, measuring 3-4.5 × 3-4 mm, is shallowly sulcate, rugulose, and sometimes pubescent. The seeds are $2-2.5 \mathrm{~mm}$ in size, ovoid, nearly smooth, rarely indistinctly pitted and pale-grey. The plant inhabits dry and sunny places at altitudes between 100 and $1800 \mathrm{~m}$, in degraded stages of Mediterranean Quercus forests. ${ }^{34-36}$

Euphorbia esula L. (leafy spurge; syn. Euphorbia pseudovirgata (Schur) Soó, E. dalechampii Haw., E. discolor Led., E. intermedia Brebis, E. racemosa Tausch., E. tristis Bess., E. triumfetti Bert., Tithymalus esula Moench.) is a glabrous or pubescent perennial herb, up to $120 \mathrm{~cm}$ in height. 
Stipules are absent, and the leaves are symmetrical at the base and stand opposite. The stems are usually unbranched at the base. It has up to 11 axillary non-flowering branches and 0-20(-30) axillary rays. The leaves, measuring $15-85 \times 0.5-15 \mathrm{~mm}$, are linear to broadly ovate or obovate, entire and bluish-green in colour, although they turn yellowish or reddish-orange in late summer. The ray-leaves are shorter and often wider than cauline. The glands have a truncated or emarginated outer margin or 2 horns. The horns of the glands are usually slender, or the outer margin of the glands is truncated or emarginated; the bracts between the male and female flowers are hirsute or plumose. The capsules measure $2.5-3 \times 3.5 \mathrm{~mm}$; they are deeply sulcated and granulated on the keels. The seeds measure $2 \mathrm{~mm}$; they are ovoid, grey or brownish. This plant occurs in Europe, but only as an alien in the north, and in North America. It flowers from May to August. ${ }^{34-36}$

Euphorbia falcata L. (syn. Euphorbia acuminata Lam.) is a glabrous, annual plant with a height of 40 $\mathrm{cm}$. The stems are simple or they have 2-3(-9) branches from the base, with 8-16 axillary rays. The leaves, measuring 5-30 $\times 3-5 \mathrm{~mm}$, are obovate-spathulate to linear-oblong, cuneate, mucronate and entire. The ray-leaves are likely to be cauline. The raylet-leaves, measuring up to $21 \times 10 \mathrm{~mm}$, are asymmetrically suborbicular or elliptic-ovate, acuminate to aristate, and subentire. It has an umbel with 4-5 rays, up to 5 times dichotomous, the whole forming a cyathium. The glands are broad and have 2 horns. The capsules measure 1.5-2 $\times 1-2.5 \mathrm{~mm}$; they are shallowly sulcate and smooth. The seeds measure $1.2 \mathrm{~mm}$; they are flattened-ovoid-quadrangular, pale-grey or brown. This plant occurs in Europe. ${ }^{34,35}$

\subsection{Chemical constituents of the family Euphorbiaceae}

This group of plants has been the subject of intense phytochemical examinations. The isolated compounds include alkaloids (imidazoles, pyrimidines, pyrrolidines, pyridines, piperidines, quinolizidines, quinazolones, isoquinolines, morphinandienones, indoles, guanidines and diterpene alkaloids), ${ }^{36,37}$ sesqui-, ${ }^{38-40}$ di- and triterpenoids (tetra- and pentacyclic), ${ }^{41-43}$ flavonoids (particularly flavones, flavonols, and rarely flavanones), ${ }^{44,45}$ coumarins (in relatively few plants), ${ }^{46}$ lignans (in only 2 genera: Jatropha and Phyllanthus) ${ }^{47}$, tannins (hydrolysable), ${ }^{48}$ phenanthrenes, quinones ${ }^{49}$ and other phenolic compounds, ${ }^{37}$ long-chain fatty alcohols ( $n$-octacosanol and $n$-hexacosanol) and hydrocarbons, alkanes and amino acids. These compounds have been isolated from the latex and from different parts (the bark, cortex, flowers, leaves, roots and stems) of the plants. The most important constituents of the latex of many Euphorbia species are triterpenes and diterpenes, mainly in ester form. ${ }^{50}$ 


\subsubsection{Diterpenoids of the family Euphorbiaceae}

Some diterpenes are ubiquitous (e.g. gibberellins) in the plant kingdom, whereas others have a more limited distribution. In particular, the macrocyclic diterpenes and their cyclization products display only a very limited distribution in the families Euphorbiaceae and Thymeleaceae. These diterpenes can be classified as 'lower terpenes' (e.g. 'Euphorbiaceae diterpenes'), derived from a geranylgeranyl pyrophosphate precursor through a 'head-to-tail' cyclization (Figure 1). ${ }^{51}$ The functionalization of diterpenes presumably proceeds after cyclization. The cembrene cation is a very reactive intermediate containing a 14-membered ring, which stabilizes through the formation of cembranoids. ${ }^{52}$ The plants in the family Euphorbiaceae produce a great variety of diterpene esters, with various biological activities. Naturally occurring diterpenes isolated from the members of Euphorbiaceae up to 2006 were reviewed by REDEI and VASAS in their PhD theses..$^{53,54}$ Up to 2006, more than 400 diterpenes were isolated from about 200 Euphorbia species, or their presence was detected. In 2008, SHI et al. reviewed the chemistry and pharmacology of the plants in the genus Euphorbia. ${ }^{55}$ Since that time, 196 new diterpenes have been isolated from 30 Euphorbia species. This section of my thesis is focused mainly on these diterpenoids and their pharmacological activities.

Cembrane diterpenes have been isolated from different plants and marine invertebrates; many have cytotoxic ${ }^{56}$, antitumour ${ }^{57}$ or HIV-1-inhibitory ${ }^{58}$ activities.

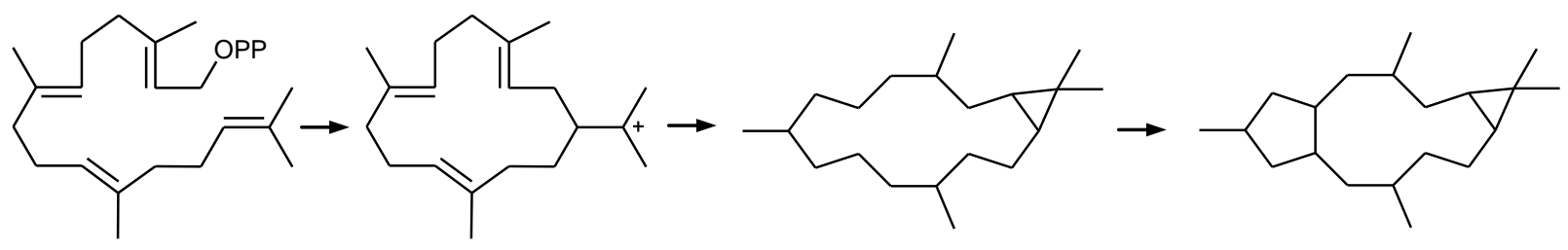

geranylgeranyl cembrene cation pyrophosphate

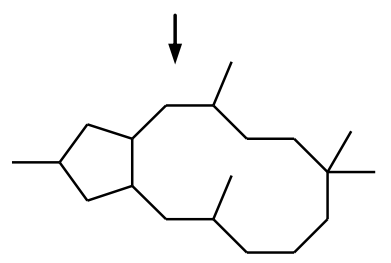

jatrophane

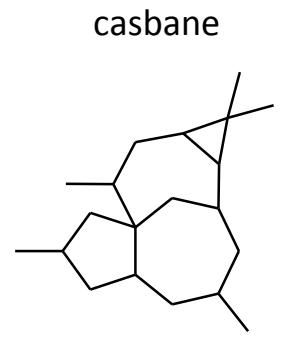

ingenane

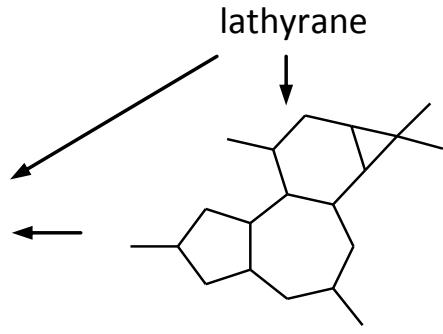

tigliane

Figure 1. Hypothetical biogenic interconversions of diterpenes in the family Euphorbiaceae

Large numbers of bicyclic diterpenes are to be found in the family Euphorbiaceae. The casbanes, formed from the cembrene cation by cyclization of the isopropanoyl group, have been considered to be precursors of a number of macrocyclic diterpenes. ${ }^{59}$ Casbanes with a trans or cis cyclopropane ring occur in the species of Euphorbia ${ }^{60,61}$ and other Euphorbiaceae genera. ${ }^{62,63}$ Some compounds have in vitro cytotoxic, ${ }^{56,59}$ antibacterial ${ }^{57}$ and antiproliferative ${ }^{57}$ activities. In 2009, LIANG et al. isolated a new casbane diterpenoid (pekinenal) with cytotoxic activity from E. pekinensis. ${ }^{10}$ The 
bicyclic jatrophane diterpenes, with a bicyclo[10.3.0]pentadecane ring system, may be formed in the plant from a cembrene cation or a casbane precursor by rearrangement. Between 2008 and 2012, 34 jatrophane and modified jatrophane diterpenes were isolated from Euphorbia species. The phytochemical investigation of E. guyoniana by El-Bassuony yielded guyonianin C and D. ${ }^{64}$ HEGAZY et $a l$. also investigated the chemical constituents of E. guyoniana and isolated 2 new components, guyonianins $\mathrm{E}$ and $\mathrm{F} .{ }^{65}$ Tuckeyanol $\mathrm{A}$ and $\mathrm{B}$, and euphotuckeyanol were isolated from E. tuckeyana, ${ }^{66}$ and further jatrophane diterpenoids (euphornin $L$ and $N$ ) from $E$. helioscopia ${ }^{67,68}$. A new macrocyclic diterpenoid, named kansuinine J, was isolated from the roots of E. kansui. This compound is esterified with an isopentanoyl group; it was recently reported in jatrophane diterpenes for the first time. ${ }^{69}$ From the fruits of $E$. sororia, 6 new jatrophane diterpenes esterified with 6 or 7 acyl groups were isolated by HUANG et al. ${ }^{70}$ Phytochemical investigation of the whole plant resulted in 3 new jatrophane diterpenoids, sororianolides A-C. ${ }^{71}$ In 2011, 2 new jatrophanes were isolated from $E$. bungei $^{72}$ In addition to 2 known jatrophanes, a new jatrophane diterpenoid, euphopeplin A, was isolated from E. peplus. ${ }^{73}$ Finally, 6 new jatrophane diterpenoids were isolated from E. dendroides. ${ }^{74}$

Many types of biological activities of jatrophanes have been reported, such as antiproliferative, ${ }^{65-67,71,75-77}$ cytotoxic, $^{67}$ multidrug resistance (MDR)-reversing, ${ }^{74,78,79}$ anti-angiogenic, ${ }^{77}$ antibacterial, ${ }^{64}$ antiviral, ${ }^{80}$ vasodepressor ${ }^{81}$ and anti-inflammatory. ${ }^{82}$

Since the 1970s, more than 190 jatrophanes from natural sources have been identified. Their great structural variability stems from the number and positions of the double bonds, the nature and number of the oxygen functions, and the configuration of the diterpene core. The oxygen functions are hydroxy, keto, epoxy, ether or ester groups. Natural jatrophane diterpenes are mainly polyacylated derivatives. The number of ester moieties ranges between $2^{83}$ and $8 .^{65}$ The acyl residues are most frequently acetyl, benzoyl, isobutanoyl, 2-methylbutanoyl or nicotinoyl, and rarely propionyl, butanoyl, angeloyl, tigloyl or cinnamoyl. The most heterogeneously esterified molecules contain 4 different acyl groups, ${ }^{74}$ and there are only a few compounds with homogeneous ester groups. ${ }^{84}$ Depending on their substitution, jatrophanes may have 5-10 chiral centres. Jatrophane diterpenes do not form a stereochemically homogeneous series, because the configurations of the carbons are variable.

Euphorbiaceae species synthesize different types of tricyclic diterpenes. One of the largest groups of tricyclic diterpenes are the lathyranes, which include about 90 compounds. The hydrocarbon nucleus of casbene and its saturated analogue, casbane, may be considered to be the biogenetic precursor of these diterpenes (Figure 1). Lathyrane diterpenes have been reported from E. lagascae (latilagascenes D-F), ${ }^{85}$ E. kansuensis, ${ }^{86}$ E. lathyris (euphorbia factor $\mathrm{L}_{8}$ ), ${ }^{87-89} \mathrm{E}$. splendida, ${ }^{90}$ E. helioscopia, ${ }^{91}$ E. bungei, ${ }^{72}$ E. aellenii ${ }^{92}$ and E. micractina ${ }^{93}$ Interestingly, the lathyrane glucoside isolated from E. helioscopia is the only Euphorbia diterpene substituted with a sugar moiety. ${ }^{91}$ 
Latilagascenes A-E, isolated from E. lagascae are the first macrocyclic lathyrane diterpenes with an oxygen function at C-16.

Pharmacological screening revealed that lathyrane-type compounds do not possess the proinflammatory activity characteristic of other Euphorbiaceae diterpenes. ${ }^{94}$

Ingols are 4,15-epoxy derivatives of lathyranes which have given rise to considerable interest as cytotoxic, ${ }^{95-97}$ vasoactive, ${ }^{17,98}$ antineoplastic, ${ }^{83}$ prostaglandin $\mathrm{E}_{2}$-inhibitory ${ }^{99}$ and anti-HIV- $1^{100}$ agents.

Ingenol esters have been isolated from E. esula, ${ }^{101,102}$ E. kansui, ${ }^{103}$ E. ebracteolata, ${ }^{104-106}$ E. laurifolia and E. lactea. ${ }^{100}$ Five of the ingenane-type diterpenes isolated from E. cornigera ${ }^{97,107}$ were esterified with the rare anthraniloyl group. Some compounds exhibited molluscicidal activity. ${ }^{107}$ In 2010, BALOCH et al. isolated 10 new ingenane-type esters from the latex of E. cauducifolia (syn. E. nerifolia). Interestingly, the diterpenes were substituted with acetyl, angeloyl, benzoyl and the rare palmitoyl and tetradecatrienoyl groups. ${ }^{108}$

Tigliane, ingenane, daphnane, jatropholane, myrsinane, premyrsinane and rhamnofolane are further common types of 'lower diterpenes' with tri- or tetracyclic skeletons (Figure 2). ${ }^{51,109}$

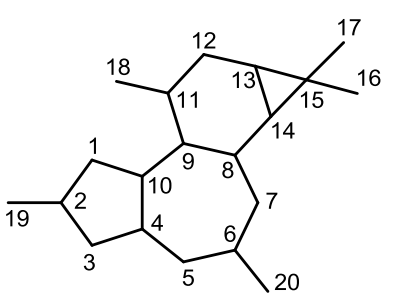

tigliane

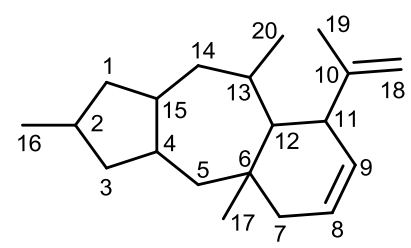

myrsinane

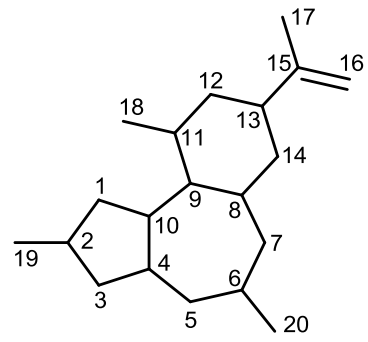

daphnane

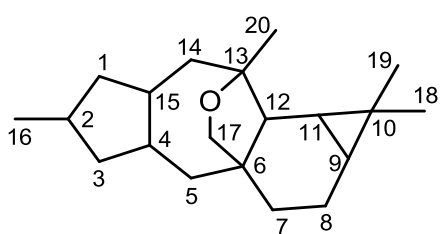

premyrsinane

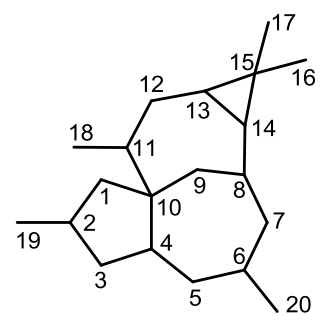

ingenane

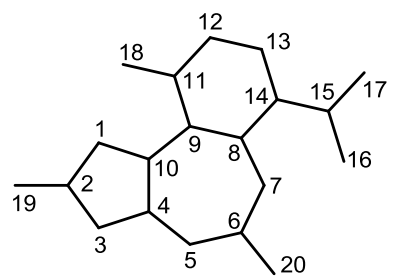

rhamnofolane

Figure 2. Skeletons of some common 'lower diterpenes' in the family Euphorbiaceae

Compounds with tigliane, ingenane or daphnane skeletons have attracted interest because of their skin-irritant activities. ${ }^{59}$ The most exhaustively investigated tiglianes are phorbols esterified on C-12 and C-13, which activate PKC; they may therefore disturb the enzyme-regulated cellular activity. 12-O-Tetradecanoylphorbol 13-acetate has become a classical activator of PKC in many studies relating to signal transduction. ${ }^{110}$ Some tiglianes exert anti-HIV-1 activity. ${ }^{111,112}$ Tiglianes have been isolated from E. cornigera, ${ }^{113}$ E. macroclada ${ }^{114}$ and the fresh latex of E. cauducifolia. ${ }^{20}$ One of the phorboids isolated from E. macroclada was an A-seco-phorboid, an unprecedented type of 
natural diterpenoids, while diterpenoids of E. cauducifolia were substituted with the rare $\mathrm{N}-(2-$ aminobenzoyl) anthraniloyl moiety. Tiglianes have also been isolated from E. fischeriana, ${ }^{115} E$. aellenii, ${ }^{116}$ E. dendroides ${ }^{74}$ and E. grandicornis. ${ }^{117}$ The structures of the 2 compounds of $E$. grandicornis differ from those of all previously known phorbol derivatives, since a 5-en-7-one or 5en-7-ol functionality is present in the molecule instead of the usual 6,7-olefin group.

Premyrsinane diterpenoids have been isolated from E. macroclada ${ }^{114}$ and myrsinanes from $E$. aellenii and E. prolifera. ${ }^{118,119}$ Further tri- and tetracyclic diterpene types have been described from the family Euphorbiaceae. These minor diterpene classes are based on pepluane, ${ }^{18,120,121}$ segetane, ${ }^{122}$ paraliane, ${ }^{123}$ jatrophatrione ${ }^{124}$ and euphoractine. ${ }^{125,126}$

Among the diterpene constituents of the family Euphorbiaceae, non-specific 'higher diterpenes' may also be mentioned. The skeletons of these compounds are formed by the classical 'concertinalike' cyclization typical of many diterpenoids, triterpenoids and steroids. Higher diterpenes, such as the bicyclic labdane ${ }^{127}$ and clerodane, ${ }^{128}$ the tricyclic abietane, ${ }^{129-133}$ and the tetracyclic bayerane, ${ }^{134}$ kaurane ${ }^{133-136}$ and atisane ${ }^{137}$ types, occur in many other plant families, too.

The absolute configurations of Euphorbia diterpenes have been investigated by X-ray analysis in only a few cases. ${ }^{119,138-142}$ The absolute configurations of all natural jatrophane derivatives are identical as concerns the ring anellation: $\mathrm{H}-4$ is $\alpha$, and $15-\mathrm{OH}$ or the 15 -acyl group is 6 -oriented.

\subsubsection{Chemical constituents of Euphorbia pannonica}

Phytochemical investigations of this plant have not been reported previously.

\subsubsection{Chemical constituents of Euphorbia esula}

Earlier chemical investigations of E. esula revealed 3 ingenane diterpenoids: ingenol 3,20dibenzoate, ingenol 3-dodecanoate, and ingenol 3- $\Delta^{2,4,6,8,10}$-pentene tetradecanoate. ${ }^{143,144}$ Macrocyclic diterpenes, viz. jatrophane esters, esulons A, B, and C, with moderately toxic and mildly inflammatory effects, have been isolated from leafy spurge roots collected in North Dakota, and lathyrane and jatrophane triesters from seeds collected in Canada. ${ }^{16,145,146}$ In the course of our earlier work, 6 new jatrophane diterpenes, named esulatins A-F, were reported from the plant. $^{22,147,148}$ In 2002, LIU et al. isolated 2 jatrophane diterpenes with cytotoxic activity from the whole herb collected in China. ${ }^{149}$ Later, ingenol esters were also isolated. ${ }^{101,102}$ From E. esula, tertiary and quaternary alkaloids, triterpenoids (24-methylenecycloartenol, cycloartenol, lupeol, lupeol acetate, $\alpha$ - and 6 -amyrin and $\delta$-amyrenone), ${ }^{33}$ steroids $\left(B\right.$-sitosterol) ${ }^{56}$ flavonoid glycosides (kaempferol 3-glucuronide), hydrocarbons, long-chain alcohols (1-hexacosanol and 1octacosanol), ${ }^{150}$ long-chain aldehydes $\left(C_{26}\right.$ and $\left.C_{28}\right),{ }^{151}$ alkanes $\left(C_{25}-C_{30}, n\right.$-triacontane, $n$ - 
hentriacontane, $n$-dotriacontane and $n$-tritriacontane), L-inositol, gallic acid, amino acids ${ }^{152}$ and rubber have also been identified.

\subsubsection{Chemical constituents of Euphorbia falcata}

Chemical investigation of E. falcata yielded $n$-nonacosane, octadecan-2-one, eicosan-2-one, pentatriacontane, obtusifoldienol, $y$-euphorbol and B-amyrin. ${ }^{153,154}$ Quercetin and its glycosides, myricetin, isomyricetin, gallic acid, 1-O-galloyl-6-D-glucose and 1-O-galloyl-4,6hexahydroxydiphenoyl-6-D-glucose were also detected in the plant. ${ }^{155,156}$

\subsection{Pharmacology of Euphorbia diterpenes}

Compounds isolated from different Euphorbia species exert many different activities, including antiproliferative, MDR-reversing, antimicrobial, vasoactive, immunomodulatory and antiinflammatory effects.

\subsubsection{Antitumour activity}

In the past few years, many investigations have been performed on the antitumour activity of Euphorbia diterpenes. Compounds with different skeletal types (e.g. casbane, abietane, ingenol, phorbol, lathyrane, myrsinane and jatrophane) proved to have moderate or strong antiproliferative effects on different human cancer cell lines (e.g. chronic myeloid leukaemia, nasopharyngeal, gastric, pancreatic, lung, ovarian and colon carcinomas). Some of them were reported to have cytotoxic activity, others inducing apoptosis. The mechanisms of actions were also investigated, and it was observed that diterpenes could be cytotoxic via inhibition of the activity of topoisomerase II and/or DNA synthesis or PKC modulation or the induction of apoptosis through either the inhibition of IL-6-induced and STAT3 activation or inhibition of the NF- $K$ B signalling pathway.

MiYATA et al. investigated the effects of ingenol diterpenes isolated from the roots of $E$. kansui on the proliferation activity of Xenopus embryo cells. Twelve diterpenes were isolated, and 8 of them induced the significant inhibition of cellular proliferation at low concentration. In order to determine the mechanism of action, the effects of these compounds on the activity of topoisomerase II were measured. It was concluded that most of the diterpenes that inhibited cellular proliferation also inhibited topoisomerase II activity. ${ }^{157}$ Later, YosHIDA et al. studied the mechanism of inhibition of topoisomerase II activity and effects on the cell proliferation through DNA damage or the blockade

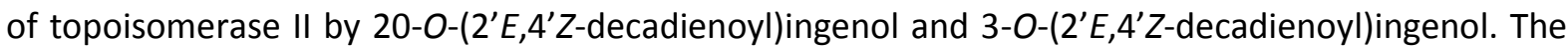
conclusion was drawn that $20-O-\left(2^{\prime} E, 4^{\prime} Z\right.$-decadienoyl)ingenol is a catalytic inhibitor of topoisomerase II. It brought about the growth arrest of mouse mammary tumour (MMT) cells in the G2/M phase of the cell cycle, without inducing $\gamma$-H2AX by DNA breaks. ${ }^{158}$ 
LUo et al. tested the cytotoxicity of jolkinolide B in human chronic myeloid leukaemia (K562), and observed that this compound displayed high activity against $\mathrm{K} 562$ cells, with an $\mathrm{IC}_{50}$ of $12.1 \mu \mathrm{g} / \mathrm{mL}{ }^{159}$ Later, WANG et al. investigated the molecular mechanism of the anti-cancer activity of jolkinolide B. It was found that it reduced cell viability and induced apoptosis in a dose- and time-dependent manner in human leukaemic cells (U937). The induction of apoptosis was accompanied by the downregulation of $\mathrm{PI3K} / \mathrm{Akt}$ and the inhibition of apoptosis protein family proteins. Moreover, jolkinolide $B$ treatment resulted in the activation of caspase-3 and $-9 .{ }^{160}$

The in vitro antiproliferative activities of helioscopinolide $E$ and $B$, isolated from $E$. tuckeyana, were investigated by DUARTE et al. against 3 human gastrointestinal cancer cell lines: gastric (EPG85257), pancreatic (EPP85-181) and colon (HT-29) carcinomas. They were inactive against the colon carcinoma cell line (HT-29) and showed moderate growth inhibitory activity on the gastric (EPG85257) and pancreatic (EPP85-181) tumour cell lines. ${ }^{66}$

The antitumour activities of 12-deoxyphorbol esters isolated from E. cornigera were investigated by BALOCH et al. Three compounds were cytotoxic, and displayed $\mathrm{IC}_{50}$ values of $0.8,0.5$ and 1.0 $\mu \mathrm{g} / \mathrm{mL}$, respectively. The mechanisms of their action in the inhibition of DNA synthesis were also investigated and a significant correlation was found between the cytotoxicity and DNA cross-link and DNA strand-break formation. ${ }^{113}$ The levels of in vitro cytotoxicity of 2 ingenol derivatives isolated from E. cornigera were evaluated against RAW (mouse macrophage cells) and HT-29 (a colon cancer cell line) by the same group, using the MTT [3-(4,5-Dimethylthiazol-2-yl)-2,5-diphenyltetrazolium bromide] assay. 3-O-(2,3-Dimethylbutanoyl)-13-O-dodecanoyl-20-O-tetradecanoylingenol exhibited significant cytotoxicity, with $\mathrm{IC}_{50}=5.0 \mu \mathrm{M}$ (RAW) and $2.90 \mu \mathrm{M}$ (HT-29). It was 5- and 1.5-fold more potent against RAW and HT-29 cancer cell lines than the standard amrubicin hydrochloride. ${ }^{97}$

Investigation of the apoptosis-inducing mechanism of 17-hydroxyjolkinolide B (HJB) revealed that HJB strongly inhibits IL-6-induced and constitutive STAT3 (signal transducer and activator of transcription) activation. Furthermore, HJB directly targets the JAK (Janus kinase) family kinases, JAK1, JAK2, and TYK2, by inducing dimerization of the JAKs via cross-linking. The effect of HJB is specific, as it has no effect on the platelet-derived growth factor, epidermal growth factor, or insulin-like growth factor 1 signalling pathways. ${ }^{161}$

YAN et al. investigated the antitumour effects of 17-acetoxyjolkinolide B and 6 analogues, isolated from $E$. fischeriana. It was concluded that these compounds irreversibly inhibit the NF-KB signalling pathway by interacting directly with IKK-B. Moreover, 17-acetoxyjolkinolide B induces apoptosis of tumour cells and acts synergistically with anticancer drugs such as doxorubicin. ${ }^{162}$

SEROVA et al. investigated the effects of PKC modulation by ingenol 3-angelate (PEPO05, ingenol mebutate) on mitogen-activated protein kinase and phosphatidylinositol 3-kinase signalling in cancer cells, and concluded that both the AKT and Ras/Raf/MAPK pathways in Colo205 colon cancer 
cells are differentially modulated by ingenol 3-angelate, and that only the latter is mediated by PKC isozymes. ${ }^{163}$ ERSVAER et al. later evaluated the balance between the efficacy and toxicity of ingenol 3angelate in the treatment of human cancer. This hydrophobic diterpene ester is strongly cytotoxic at high concentration $(100 \mu \mathrm{g} / \mathrm{mL})$, while at concentrations of $10-100 \mathrm{ng} / \mathrm{mL}$ it is a selective activator of PKC. ${ }^{164,165}$ Ingenol 3-angelate has both anticancer and proinflammatory effects, which is an advantage in topical skin application, but it can be dangerous in the event of systemic therapy. In conclusion, the authors established that extensive in vivo experimental models and carefully designed clinical studies can clarify whether the systemic use of this compound will be acceptable with regard to the risk of toxicity. ${ }^{166}$

TAO et al. investigated the cytotoxic activity of jatrophane diterpenes, isolated from $E$. helioscopia, using HL-60 cells by the MTT method and A-549 cells by the SRB (sulphorhodamine B) method. Two compounds (euphornin L and euphoscopin F) exhibited cytotoxicity against HL-60, with $\mathrm{IC}_{50}$ values of 2.7 and $9.0 \mu \mathrm{M}$, respectively, while the other compounds were inactive. ${ }^{67}$ Guyonianins $E$ and $F$ and 5,7,14-triacetoxy-3-benzoyloxy-15-hydroxy-9-oxojatropha-6(17),11E-diene isolated from E. guyoniana were investigated for cytotoxic activity by HEGAZY et al. 5,7,14-Triacetoxy-3-benzoyloxy15-hydroxy-9-oxojatropha-6(17),11E-diene exhibited significant activity $\left(\mathrm{IC}_{50}=35 \mu \mathrm{M}\right)$, and guyonianins $\mathrm{E}$ and $\mathrm{F}$ moderate activity $\left(\mathrm{IC}_{50}=70\right.$ and $100 \mu \mathrm{M}$, respectively) against human embryonic kidney 293 (HEK293) cells. ${ }^{65}$ Investigation of the anticancer characteristics of euphodendrophane A and $\mathrm{B}$ on a sensitive non-small cell lung cancer cell line $(\mathrm{NCl}-\mathrm{H} 460)$ and its resistant counterpart ( $\mathrm{NCl}-$ $\mathrm{H} 460 / \mathrm{R}$ ) demonstrated that these compounds inhibited the growth of these cancer cells and were non-toxic for peripheral blood mononuclear cells (PBMS). ${ }^{77}$

The cytotoxic activity of pekinenal was investigated against 4 human cancer cell lines, $\mathrm{NCl}-\mathrm{H} 460$ (lung), KB (nasopharyngeal), SGC7901 (gastric) and HO-8910 (ovarian), by the MTT assay. The compound exhibited cytotoxic activity, with $\mathrm{IC}_{50}$ values of $10.05,8.52,13.82$, and $14.16 \mu \mathrm{g} / \mathrm{mL}$, respectively. ${ }^{10}$ WANG et al. evaluated the cytotoxicities of compounds isolated from $E$. fischeriana against human cancer cell lines, MDA-MB-231 and HepG2, and a human immortalized cell line (HEK293). Only 12-deoxyphorbol-13-hexadecanoate was found to be cytotoxic against MDA-MB-231 cells $\left(I_{50}=6.694 \mu \mathrm{M}\right) .{ }^{115}$ In the following year, ZHANG et al. investigated the antiproliferative activity of euphorbia factor $L_{3}$ against a lung cancer cell line (A549) in vitro. It was found to show potent cytotoxicity and to induce apoptosis via the mitochondrial pathway in A549 cells, with involvement of the loss of mitochondrial potential and the release of cytochrome $\mathrm{C}^{89}$ The cytotoxicities of proliferins A, B and D, isolated from E. prolifera, were evaluated against various cancer cells (HCT-8, Bel-7402, BGC-823, A549 and A2780). Only proliferin A proved to be cytotoxic against A2780 human ovarian cancer cells $\left(\mathrm{IC}_{50}=7.7 \mu \mathrm{M}\right) .{ }^{167}$ 
Human cytomegalovirus (CMV) preferentially infects tumour tissues, and the accumulated CMV immediate-early (IE) antigen may lead to tumour promotion and progression. The development of strategies to inhibit the human CMV IE antigen expression and/or function is an important goal as concerns the prevention and treatment of certain forms of cancers associated with human CMV. PUSZTAl et al. investigated the effects of the lathyrane-type latilagascenes A-E and jolkinol B on CMV IE antigen expression in lung cancer cells. It was concluded that latilagascene E demonstrated the highest activity, while latilagascene $D$ was inactive. ${ }^{168}$

\subsubsection{Multidrug resistance-reversing activity}

MDR is a major obstacle in the chemotherapeutic treatment of cancer. MDR can be reversed by drugs that vary widely in their chemical structure and main biological action. Special attention is paid to P-glycoprotein (P-gp)-related MDR as the most experimentally and clinically tested form of drug resistance. P-gp, one of the most important and best-studied $A B C$ transporter proteins, acts as an energy-dependent pump of chemotherapeutic agents, thereby decreasing the intracellular concentration of drugs and resulting in MDR.

JIAO et al. investigated the MDR activities of lathyrane diterpenes isolated from $E$. lathyris on MCR7/ADM cell lines in vitro. It was concluded that the position of the double bond between C- 6 and $\mathrm{C}-7$, and substitution on $\mathrm{C}-7$ are important factors relating to the capability of inhibition. The most active compound was 7-hydroxylathyrol, while isolathyrol showed moderate activity.

DUARTE et al. derivatized latilagascene B, previously isolated from E. lagasce, to yield 3 new lathyrane esters: latilagascene G, H and I. Their MDR-inhibitory activities were investigated together with those of tuckeyanols $A$ and $B$, euphotuckeyanol, latilagascene $A-F$ and jolkinol B. Structureactivity relationship studies were also carried out. ${ }^{76}$ Later, they evaluated the MDR-reversing and apoptosis-inducing activities of latilagascenes $\mathrm{A}-\mathrm{F}$ and jolkinol, isolated from E. lagascae. All these compounds were shown to enhance drug retention in the cells by inhibiting the efflux-pump activity, mediated by P-gp. Latilagascene E displayed the highest effect (FAR $=216.8$, at $4 \mu \mathrm{g} / \mathrm{mL}$; FAR is defined in section 5.4). Moreover, the in vitro effects of latilagascene $B$ in combination with doxorubicin on human MDR1 gene-transfected mouse lymphoma cells were also examined. A synergistic interaction was observed between the 2 compounds (FIX $=0.292 ; \mathrm{FIX}$ is defined in section 5.4). In the case of apoptosis induction, it was found that latilagascene $B$ was the most active at the highest concentration. ${ }^{85}$ LAGE et al. also investigated macrocyclic diterpenes (latilagascenes B, C and $D$, jolkinol B, ent-16 $\alpha$-hydroxyatisane-3-one and ent-16 $\alpha$,17-dihydroxykauran-3-one isolated from $E$. lagasce, and helioscopinolides A, B, D and E from E. tuckeyana, an acetylation reaction product of

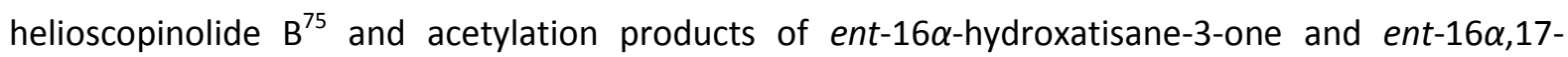
dihydroxykauran-3-one ${ }^{169}$ ) for their potential antineoplastic activity on gastric (EPG85-257), 
pancreatic (EPP85-181) and colon (HT-29) human carcinoma cell lines. Furthermore, the effects of these diterpenes on different multidrug-resistant variants of these cancer cell lines over-expressing MDR1/P-gp or without MDR1/P-gp expression were also evaluated. The most active compounds were the lathyrane diterpenes latilagascenes $\mathrm{C}$ and $\mathrm{D}$, and the diterpene lactones 36acetoxyhelioscopinolide B and helioscopinolide E, which exhibited high antineoplastic activities against the drug-resistant EPG85-257 cell line. In addition, jolkinol B was found to be highly effective in the multidrug-resistant HT-29 cell line. ${ }^{169}$

In the search for MDR-reversing compounds from natural sources, a series $(n=32)$ of Euphorbia diterpenes were tested by MoLnÁR et al. on mouse lymphoma cells, using the rhodamine 123 exclusion test. The diterpenes investigated represented various skeletal types, e.g. jatrophanes, lathyranes and 'euphoractine-type' compounds. The results showed that structurally different ditepene polyesters may display significant MDR-reversal effects. ${ }^{78}$ In another screening programme, COREA et al. investigated the MDR-modulatory activities of 62 diterpenes isolated previously from Euphorbia species (E. dendroides, E. characias, E. peplus, E. paralias and E. helioscopia). Since these compounds were based on a structurally homogeneous skeleton, with differences only in the substitution pattern, a structure-activity relationship study was possible. Among others, it was concluded that the presence of hydroxy groups on C-3 and C-15, acetyl groups on C-8 and C-9 and a keto group on C-14 in jatrophanes increased the anti-MDR activity, while the presence of a hydroxy group on C-2, an acetyl group on C-14, and nicotinoyl groups on C-5 and C-9 reduced the inhibitory potency of the compounds. ${ }^{79}$

In 2011, ZHANG et al. investigated the MDR-reversing potency and the detailed mechanisms of actions of euphorbia factor $L_{1}$. It was concluded that this compound potentiated the sensitivity of the $A B C B 1$ substrates investigated and increased the accumulation of doxorubicin and rhodamine 123 in ABCB1-mediated MDR KBv200 and MCF7/adr cells. The activity of euphorbia factor $L_{1}$ is related to its being a stimulator of $A B C B 1$ ATPase activity and an inhibitor of the efflux of $A B C B 1$ in KBv200 and MCF7/adr cells. Moreover, euphorbia factor $L_{1}$ did not downregulate the expression of $A B C B 1$ at either an mRNA or a protein level. ${ }^{170}$

The effects of euphodendrophane A and B in combination with paclitaxel (PTX) were examined. These jatrophanes overcome PTX resistance in a concentration-dependent manner in MDR cancer cell line ( $\mathrm{NCl}-\mathrm{H} 460 / \mathrm{R})$, as they induce cell killing and change the cell cycle distribution, leading to a G2/M arrest. Furthermore, these compounds exert an anti-angiogenic effect by decreasing vascular endothelial growth factor secretion. ${ }^{74,77}$

The MMP-2 and -9 (matrix metalloprotein)-modulating activities of diterpenes isolated from $E$. formosana on human fibrosarcoma cell line HT1080 were investigated by YU et al. Among them, 3hydroxy-ent-abietane compounds [helioscopinolide A-C and ent- $(56,8 \alpha, 96,10 \alpha, 12 \alpha(-12$-hydroxyatis- 
16-ene-3,14-dione)] significantly up-regulated the expressions of MMP-2 and -9 at concentrations of 10 and $50 \mu \mathrm{M}^{132}$

\subsubsection{Immunomodulatory activity}

The immunomodulatory effect of 14 -desoxo- $36,5 \alpha, 76,10,156$-O-pentaacetyl-14 $\alpha$-O-benzoyl-10,18dihydromyrinsol isolated from E. aellenii was investigated on the oxidative burst activity of wholeblood phagocytes and the proliferation of human peripheral blood lymphocytes. In concentrations of $0.5,5$ and $50 \mu \mathrm{g} / \mathrm{mL}$, the compound resulted in the dose-dependent suppression of T-cell proliferation by $39 \pm 5.0,68 \pm 2.0$ and $72 \pm 1.6 \%$, respectively. ${ }^{118}$ Later, the immunomodulating potentials of tigliane diterpenes isolated from E. aellenii were tested by GHANADIAN et al., using neutrophils of human whole blood. It was concluded that 4-deoxy-4 $\alpha$-phorbol-12-(2,3dimethyl)butyrate-13-isobutyrate exhibited moderate inhibitory activity against both T-cell proliferation and reactive oxygen species production, with $\mathrm{IC}_{50}=14$ and $44.1 \mu \mathrm{g} / \mathrm{mL}$, respectively. ${ }^{116}$

The in vitro anti-inflammatory activities of 4 jolkinolides (jolkinolide $A$ and $B$, and 17-hydroxyjolkinolide A and B) in lipopolysaccharide-stimulated RAW264 macrophages were investigated by UTO et al. Among them, 17-hydroxy-jolkinolide B (HJB) exhibited the most potent inhibition of the LPS-induced production of inflammatory mediators such as $\mathrm{PGE}_{2}, \mathrm{NO}$, and pro-inflammatory cytokines IL- 6 and TNF- $\alpha$. These inhibitory effects were caused by the suppression of MAPK phosphorylation and NF-KB activation. ${ }^{171}$

\subsubsection{Anti-inflammatory activity}

Pepluanone, a diterpene component of E. peplus, possesses a high anti-inflammatory property in vivo. Furthermore, in vitro assays of pepluanone on LPS-stimulated $\mathbf{J 7 7 4}$ murine macrophages showed that it reduced the production of NO, PGE2 and TNF- $\alpha$ by reducing the expression of iNOS, COX-2 and TNF- $\alpha$ mRNA, respectively. ${ }^{172}$ BARILE et al. tested the anti-inflammatory activities of compounds with pepluane and paraliane skeletons, isolated from E. paralias. In this assay, one of the isolated compounds showed high activity, comparable to that found for pepluanone. ${ }^{123}$

NUNOMURA et al. investigated the effects of 3-O-(2,3-dimethylbutanoyl)-13-O-decanoylingenol (DBDI), isolated previously from the roots of $E$. kansui, ${ }^{173}$ on the activation of intracellular signalling pathways and the release of inflammatory chemical mediators in bone marrow-derived mouse mast cells (BMMCs) upon FceRI stimulation. It was revealed that DBDI significantly inhibits the $\left[\mathrm{Ca}^{2+}\right]_{\mathrm{i}}$ increase, the 6 -hexosaminidase release and the synthesis of $P G D_{2}, P G E_{2}$ and $L T C_{4}$ in $B M M C s$ stimulated with IgE and multivalent antigen complex. Moreover, they demonstrated that DBDI inhibits the activation of intracellular signalling molecules, including Syk, PLC- $\gamma 2$ and ERKI/2. ${ }^{174}$ 
In 2010, CHANG et al. reported that IL-6-induced Stat3 activation was inhibited by kansuinine A and $B$ in HepG2 cells. Moreover, they established that ERK1/2 activation by these compounds could be a key player for the downregulation of IL-6-induced Stat3 activation. ${ }^{82}$

\subsubsection{Antiviral activity}

The persistence of latent HIV-infected cellular reservoirs is the major hurdle to virus eradication in patients treated with highly active antiretroviral therapy. Prostratin and other non-tumourigenic PKC agonists reactivate HIV-1 latency in vitro by activating NF-KB through a PKC-dependent pathway. The effects of extracts and fractions from the latex of E. laurifolia and E. lactea on HIV-1 reactivation in Jurkat-LAT-GFP cells were evaluated by AVILA et al. 3,12-Di-O-acetyl-8-O-tigloylingol, isolated from $E$. lactea, was able to reactivate HIV-1 latency in a concentration-dependent manner. Other investigated compounds were significantly less active. Due to the structural similarity between $3,12-$ di-O-acetyl-8-O-tigloylingol and phorbol esters such as PMA and prostratin, the role of PKC in 3,12di-O-acetyl-8-O-tigloylingol-induced HIV-1 reactivation was studied. It was concluded that 3,12-di-Oacetyl-8-O-tigloylingol reactivates HIV-1 through a PKC-dependent pathway. ${ }^{100}$

BEDOYA et al. investigated the antiviral activity of a series of previously isolated jatrophane diterpenes. It was found that one of the compounds, SJ23B, exerted potent antiviral activity through the downregulation of HIV receptors and the induction of viral reactivation. In this investigation, the activity of SJ23B was 10 -fold more potent than that of prostratin. Moreover, this compound activated PKC and was able to activate cells where HIV is hidden as a latent provirus. ${ }^{80}$

TIAN et al. investigated the antiviral activities of lathyrane diterpenoids. It was established that 15-cinnamoyloxylathyra-5,12-dien-3-ol-14-one showed in vitro activity against HIV-1 replication $\left(\mathrm{IC}_{50}=8.2 \mu \mathrm{M}\right){ }^{93}$

\subsubsection{Antibacterial activity}

Screening of the in vitro antibacterial activities of guyonianin C and D by EL-BASSOUNY on Grampositive (Bacillus cereus and Staphylococcus aureus) and Gram-negative (Serratia sp. and Pseudomonas sp.) bacteria, demonstrated that guyonianin C possesses activity against $B$. cereus. ${ }^{64}$

\subsubsection{Vascular-relaxing activity}

Lathyrane diterpenoids isolated from E. micractina displayed significant vascular-relaxing activities against phenylephrine-induced vasoconstriction, with relaxation rates of $41-53 \%$; the positive control verapamil exhibited a $44 \%$ relaxation at the same concentration. ${ }^{93}$ In 2006 , BARLA et al. isolated a jatrophane diterpene ester from the aerial parts of $E$. helioscopia, which was found to have mild vasodepressor activity. ${ }^{81}$ 


\subsubsection{Proinflammatory activity}

SHU et al. investigated the proinflammatory constituents of E. kansui. The results showed that kansuinines $A$ and $B$ and 3-O-(2'E,4'Z-decadienoyl)-20-O-acetylingenol markedly promoted proliferation of the splenic lymphocytes of exoteric mice and NO production by rat peritoneal macrophages at concentrations from 0.78 to $12.50 \mu \mathrm{g} / \mathrm{mL}$. The three compounds are therefore believed to be important proinflammatory components of the roots of E. kansui. ${ }^{175}$ It was also reported that kansuinines $A$ and $B$ had antiviral and anticancer activities, ${ }^{176,177}$ indicating that these compounds are responsible for both pharmacological activity and toxicity.

\subsubsection{Pesticidal activity}

The $\mathrm{MeOH}$ extract of the roots of $E$. kansui exerted pesticidal activity against the brown plant hopper (Nilaparvatal ugens Stal) and the two-spotted spider mite (Tetranychus urticae Koch). Bioassay-guided fractionation led to the isolation of 3-O-(2,3-dimethylbutanoyl)-13-Ododecanoylingenol and 3-O-(2'E,4'Z-decadienoyl)ingenol. ${ }^{19}$ The 2 diterpenes showed greater activity against the brown plant hopper as compared with anise oil and eugenol. The calculated $L_{50}$ doses were $0.139 \mu \mathrm{g} /$ insect for 3-O-(2,3-dimethylbutanoyl)-13-O-dodecanoylingenol and $0.111 \mu \mathrm{g} /$ insect for 3-O-(2'E,4'Z-decadienoyl)ingenol.

GENG et al. investigated the feeding deterrent activities of diterpenes isolated from E. fischeriana. Jolkinolide $B$ and hydroxyjolkinolide $B$ possessed strong feeding deterrent activities against Sitophilus zeamais $\left(\mathrm{EC}_{50}=342.1\right.$ and $543.9 \mathrm{ppm}$, respectively) and Tribolium castaneum adults $\left(\mathrm{EC}_{50}=361.4\right.$ and $551.5 \mathrm{ppm}$, respectively). ${ }^{136}$

\subsubsection{Molluscicidal activity}

BALOCH et al. investigated the molluscicidal activities of extracts $\left(\mathrm{CCl}_{4}, \mathrm{Et}_{2} \mathrm{O}, \mathrm{CHCl}_{3}, \mathrm{Me}_{2} \mathrm{CO}\right.$, EtOAc, $\mathrm{EtOH}$ and $\mathrm{MeOH}$ ) of the roots of E. cornigera, on the freshwater snail Biomphalaria glabrata, an intermediate host of Schistosoma mamsoni. Bayluscide was used as positive control. The $\mathrm{Me}_{2} \mathrm{CO}$ extract displayed significant activity $\left(\mathrm{IC}_{50}=15.5 \mu \mathrm{g} / \mathrm{mL}\right)$. Further purification of this extract resulted in the isolation of 10 ingenol-type diterpene polyesters. Eight of the isolated compounds exhibited relatively high activity against the intermediate snails. ${ }^{107}$ Later, BALOCH et al. investigated the molluscicidal effects of 8 phorbol derivatives isolated from E. cauducifolia against B. glabrata snails. Two compounds, with an acetyl or an $\mathrm{N}$-(2-aminobenzoyl)anthraniloyloxy moiety at C-13, had higher activities than that of bayluscide, while other compounds were equipotent to the control niclosamide. The compounds probably induce osmosnailic instability and surface vesiculation, leading to the death of the snails. ${ }^{20}$ 


\subsection{Folk-medicinal use of the investigated Euphorbia species}

As concerns E. pannonica, neither any folk-medicinal use nor any pharmacological investigation has yet been published.

E. esula is toxic to livestock, and allelopathic to desirable forage plants. ${ }^{150}$ It is known to cause sheep mortality and to produce inflammation with the loss of hair from the feet of horses. The latex causes blistering with severe irritation if allowed to remain on the skin, and it can lead to partial blindness if dropped into the eyes. ${ }^{144}$ Extracts of the plant have been widely used in folk medicine to treat various cancers, swellings and warts. ${ }^{5}$ The main traditional uses were proved by pharmacological investigations. Previous pharmacological studies demonstrated the proinflammatory, tumour-promoting and antitumour activities of the plant extracts. ${ }^{178-180}$ The extracts of $E$. esula exhibited antileukaemic activity against P-388 lymphocytic leukaemia in mice. ${ }^{143}$

E. falcata has not been used in traditional medicine. 


\section{AIMS OF THE STUDY}

The Euphorbia genus is the source of a large number of biologically active diterpenes. In 1995, HOHMANN et al. (Department of Pharmacognosy, University of Szeged) initiated a research programme with the aim of investigating the secondary metabolites of plants of the Euphorbia species. The aims of the present work, as part of that programme, were the isolation and structural characterization of new diterpene polyesters, and investigation of their pharmacological effects.

In order to achieve these aims, the main tasks were:

- Screening of E. pannonica and E. falcata for diterpene content.

- Extraction of the plant materials.

- Isolation and purification of the diterpene esters from E. pannonica, E. esula and E. falcata by a combination of various chromatographic methods (OCC, VLC, RPC, PLC and HPLC).

- Characterization and structure determination of the isolated compounds by different spectroscopic techniques (NMR and HR-MS).

- Evaluation of the pharmacological potential and chemotaxonomical relevance of the isolated diterpenes. 


\section{MATERIAL AND METHODS}

\subsection{Plant material}

E. pannonica: Aerial parts $(5.1 \mathrm{~kg})$ were collected in the flowering period from wild stock near Kiscsala-Császártöltés, Hungary, in June 2005. The plant material was identified by Dr. Tamás Rédei (Institute of Ecology and Botany of the Hungarian Academy of Sciences, Vácrátót, Hungary).

E. esula: Whole plants (8 kg) were collected in June 2004 on the banks of the River Tisza, in Szeged, Hungary, and identified by Dr. Tamás Rédei. The fresh plant material was frozen and stored at $-20^{\circ} \mathrm{C}$ until preparation.

E. falcata: Whole plants $(20 \mathrm{~kg}$ ) were collected in September 2008 in Mosonmagyaróvár, Hungary. The plant material was identified by Dr. Gyula Pinke (Department of Botany, Faculty of Agricultural and Food Sciences, University of West Hungary, Mosonmagyaróvár, Hungary). The fresh plant material was frozen and stored at $-20^{\circ} \mathrm{C}$ until preparation.

\subsection{Screening of plant material for diterpene content}

$20 \mathrm{~g}$ each of fresh and crushed plant materials (E. pannonica and E. falcata) were percolated with $200 \mathrm{~mL}$ of $\mathrm{MeOH}$ at room temperature. After concentration (to $30 \mathrm{~mL}$ ), $30 \mathrm{~mL}$ of $\mathrm{H}_{2} \mathrm{O}$ was added to the extract and the mixture was subjected to solvent partitioning with $4 \times 30 \mathrm{~mL}$ of $\mathrm{CH}_{2} \mathrm{Cl}_{2}$. The $\mathrm{CH}_{2} \mathrm{Cl}_{2}$-soluble phase was subjected to polyamide $(1 \mathrm{~g}) \mathrm{OCC}$, using a solvent system of $\mathrm{MeOH}-\mathrm{H}_{2} \mathrm{O}$ $[1: 4,2: 3,3: 2$ and $4: 1$ (200 $\mathrm{mL}$ of each mixture)] as eluent. The fractions were concentrated and monitored by TLC, using a mobile phase of cyclohexane-EtOAc-EtOH (30:10:1) and $\mathrm{CHCl}_{3}-\mathrm{Me}_{2} \mathrm{CO}$ (19:1).

Mobile phases in all types of chromatography methods are given in terms of volume ratio, $\mathrm{v} / \mathrm{v}$.

\subsection{Extraction and isolation of diterpenes}

\subsubsection{Extraction}

The fresh E. pannonica, and the frozen E. esula and E. falcata plant material were crushed with a Waring CB-6 commercial blender (model 33BL13). The raw materials were percolated with $\mathrm{MeOH}$ $(30 \mathrm{~L}, 60 \mathrm{~L}$ and $178 \mathrm{~L}$ ) at room temperature in a glass percolator (diameter $15 \mathrm{~cm}$, height $35 \mathrm{~cm}$ ). The extracts were concentrated using a Rotavapor R-210 ( $40{ }^{\circ} \mathrm{C}, 337 \mathrm{mbar}$ ). $\mathrm{H}_{2} \mathrm{O}$ (500 mL, $1000 \mathrm{~mL}$ and $2500 \mathrm{~mL}$ ) was added to the extracts after concentration, and solvent-solvent partition was then performed with $\mathrm{CH}_{2} \mathrm{Cl}_{2}$ in the cases of E. pannonica and E. esula $(5 \times 1000 \mathrm{~mL}$ and $5 \times 1500 \mathrm{~mL})$ and with $\mathrm{CHCl}_{3}$ for the $E$. falcata $(15 \times 2000 \mathrm{~mL})$ mixture. 


\subsubsection{Isolation and purification of compounds}

Open-column chromatography: OCC was performed on polyamide for column chromatography (ICN) (113 $\mathrm{g}$ for the E. pannonica extract, $500 \mathrm{~g}$ for the E. esula extract and $1100 \mathrm{~g}$ for the E. falcata extract). Mixtures of $\mathrm{MeOH}-\mathrm{H}_{2} \mathrm{O}$ [2:3, 3:2, 4:1 (E. pannonica $4 \mathrm{~L}$, E. esula $5 \mathrm{~L}$ and E. falcata $10 \mathrm{~L}$ of each)] were used as mobile phase for the plant extracts, with the exception of $E$. esula, where the elution was performed with $\mathrm{MeOH}-\mathrm{H}_{2} \mathrm{O}(1: 4)$ in the first step.

Vacuum-liquid chromatography: For VLC, silica gel $60 \mathrm{GF}_{254}(15 \mu \mathrm{m}$, Merck 11677) was used. The dissolved extracts were added to one-tenth of the silica gel. After drying, the powdery materials were placed on the remainder of the stationary phase in a filter funnel. The VLC columns were developed under gentle vacuum, provided by a water pump. Elutions were performed with a stepwise gradient.

Rotation planar chromatography: RPC was carried on a Harrison Model 8924 Chromatotron instrument (Harrison Research). The stationary phase for RPC was silica gel $60 \mathrm{GF}_{254}$ (Merck 7730), manually coated on the rotor as a 1 or 2 or $4 \mathrm{~mm}$ layer. The separation by RPC was achieved with gradient elution in 5 or 6 steps. The flow rates were from 4 to $8 \mathrm{~mL} / \mathrm{min}$.

Preparative layer chromatography: PLC was performed on $20 \times 20 \mathrm{~cm}$ silica plates (silica gel $60 \mathrm{~F}_{254}$, Merck 5715). The plates were developed by an ascending technique in a glass chamber at room temperature. Separation was monitored in daylight after spraying the border of the plates with conc. $\mathrm{H}_{2} \mathrm{SO}_{4}$ (then heating at $110{ }^{\circ} \mathrm{C}$ for $5 \mathrm{~min}$ ) or in ultraviolet (UV) light at $254 \mathrm{~nm}$. Compounds were eluted from the scraped adsorbent with $\mathrm{CHCl}_{3}$.

The whole isolation procedure was monitored by using TLC on silica gel $60 \mathrm{~F}_{254}$ (Merck 5554). The visualization methods involved UV light at $254 \mathrm{~nm}$, after spraying with conc. $\mathrm{H}_{2} \mathrm{SO}_{4}$, and then heating at $110^{\circ} \mathrm{C}$ for $5 \mathrm{~min}$; the spots were visualized in daylight.

High-performance liquid chromatography: HPLC was carried out on a pre-packed Hibar RT (250 mm, $4 \mathrm{~mm}$ ) LiChrospher Si $100(5 \mu \mathrm{m})$ column (Merck), on a pre-packed Hibar RT ( $250 \mathrm{~mm}, 10 \mathrm{~mm}$ ) LiChrospher RP-18 $(10 \mu \mathrm{m})$ column (Merck) and on a pre-packed Hibar RT (250 mm, $4 \mathrm{~mm})$ LiChrospher RP-18 (5 $\mu \mathrm{m}$ ) column (Merck), using a Waters instrument: Controller 600, a Pump 600, a Dual $\lambda$ Absorbance Detector 2487, a Photodiode Array Detector 2998, and an Injector Rheodine 7725i. Chromatographic separations were monitored at 254 and $288 \mathrm{~nm}$. 


\subsection{Characterization and structure determination of the isolated compounds}

ESIMS measurement was carried out on an Applied Biosystems 3200 QTap spectrometer in ion trap mode. The HREIMS measurements were made on a VG-ZAB-SEQ sector instrument with an electron impact ion source. The resolution of the instrument was 10 000. The HRESIMS data were recorded, in the cases of E. esula, on a Shimadzu IT-TOF and for the E. falcata, on a Waters-Micromass Q-TOF spectrometer. Both instruments were equipped with electrospray source.

NMR spectra were recorded on a Bruker DRX 500 spectrometer at $500 \mathrm{MHz}\left({ }^{1} \mathrm{H}\right)$ and $125 \mathrm{MHz}\left({ }^{13} \mathrm{C}\right)$, and a Bruker DRX 600 spectrometer at $600 \mathrm{MHz}\left({ }^{1} \mathrm{H}\right)$ and $200 \mathrm{MHz}\left({ }^{13} \mathrm{C}\right)$, with $\mathrm{CDCl}_{3}$ or $\mathrm{MeOD}$ as solvent and tetramethylsilane (TMS) as internal standard. Two-dimensional (2D) experiments were performed with standard Bruker software.

Optical rotation values were determined in $\mathrm{CHCl}_{3}$ by using a Perkin-Elmer 341 polarimeter. 


\section{RESULTS}

\subsection{Screening of E. pannonica and E. falcata for diterpene contents}

The extraction and sample preparation were carried out as described in section 3.2. As concerns the screening results on E. pannonica and E. falcata, the TLC chromatograms of fractions eluted with $\mathrm{MeOH}-\mathrm{H}_{2} \mathrm{O}$ (3:2) (E. pannonica) and (2:3) and (3:2) (E. falcata) yielded brown, purple, blue and black spots of diterpenes with $R_{f}$ values of 0.07-0.89 [mobile phase: cyclohexane-EtOAc-EtOH (30:10:1)]. The fractions eluted with $\mathrm{MeOH}-\mathrm{H}_{2} \mathrm{O}$ (4:1) contained mainly triterpenes and fats. These observations led to the conclusion that the extracts of E. pannonica and E. falcata contain a series of different diterpene esters, which can be enriched in the $40 \%$ and $60 \% \mathrm{MeOH}$ fractions of the apolar extracts of the plants.

\subsection{Isolation of diterpenes}

\subsubsection{Isolation of diterpenes from E. pannonica}

The aerial parts of E. pannonica $(5.1 \mathrm{~kg})$ were milled and percolated with $\mathrm{MeOH}(30 \mathrm{~L})$ at room temperature. The $\mathrm{MeOH}$ extract was evaporated, using a Rotavapor $\left(40{ }^{\circ} \mathrm{C}, 337 \mathrm{mbar}\right)$. The extract was then subjected to solvent-solvent partitioning with $\mathrm{CH}_{2} \mathrm{Cl}_{2}$ to remove polar compounds (Figure 3). The organic phase was concentrated. This residue (56.6 g) was dissolved in $\mathrm{CH}_{2} \mathrm{Cl}_{2}$ and adsorbed onto a polyamide stationary phase (113 g) to remove chlorophyll and triterpenes from the extract. The stationary phase was previously suspended in $40 \% \mathrm{MeOH}(1 \mathrm{~L})$. The diterpenoids were eluted from the polyamide sorbent with $\mathrm{MeOH}-\mathrm{H}_{2} \mathrm{O}$ (2:3, 3:2, 4:1, v/v; $4 \mathrm{~L}$ each). Normal-phase (NP)-TLC analysis indicated that the fraction eluted with $\mathrm{MeOH}-\mathrm{H}_{2} \mathrm{O}(3: 2)$ contained a series of diterpenoids, which were separated by further chromatographic procedures.

The diterpene-containing fraction was evaporated to dryness $(3.2 \mathrm{~g})$. This fraction was subjected to silica gel VLC, using a gradient system of cyclohexane- $\mathrm{CHCl}_{3}-\mathrm{Me}_{2} \mathrm{CO}$ (3:2:0, 1:1:0, 2:3:0, 3:7:0, 1:4:0, 10:40:1, 4:16:1 and 1:4:1,). $50 \mathrm{~mL}$ fractions were collected. Combined fractions 17-33 (0.25 g) were further fractionated by RPC, using a gradient system of $n$-hexane-EtOAc mixtures (19:1, 9:1, 17:3, 4:1, 3:1 and 7:3, v/v; $60 \mathrm{~mL}$ each, flow $=7 \mathrm{~mL} / \mathrm{min}, 2 \mathrm{~mm}$ layer). The fractions containing diterpenes (fractions I and II) were separated on RPC, using a cyclohexane-EtOAc gradient system (100:0, 49:1, 19:1, 93:7, 9:1 and 17:3). Subfractions 74-76 of fraction I were further purified by preparative TLC on silica gel with cyclohexane-EtOAc (4:1). Final purification was carried out by reversed-phase (RP) preparative TLC with a solvent system of $\mathrm{MeCN}-\mathrm{H}_{2} \mathrm{O}(4: 1)$ to afford $4.2 \mathrm{mg}$ of EPAN-3 (1). Subfractions 29-37 from the RPC separation of fraction II were subjected to preparative 
TLC with $n$-hexane- $\mathrm{CHCl}_{3}-\mathrm{Me}_{2} \mathrm{CO}$ (50:50:3), and finally purified by RP-HPLC, using $\mathrm{MeCN}-\mathrm{H}_{2} \mathrm{O}$ (13:7) as mobile phase (flow $=1.2 \mathrm{~mL} / \mathrm{min} ; t_{\mathrm{R}}=8.3 \mathrm{~min}$ ) to yield $3.6 \mathrm{mg}$ of EPAN-7 (2).

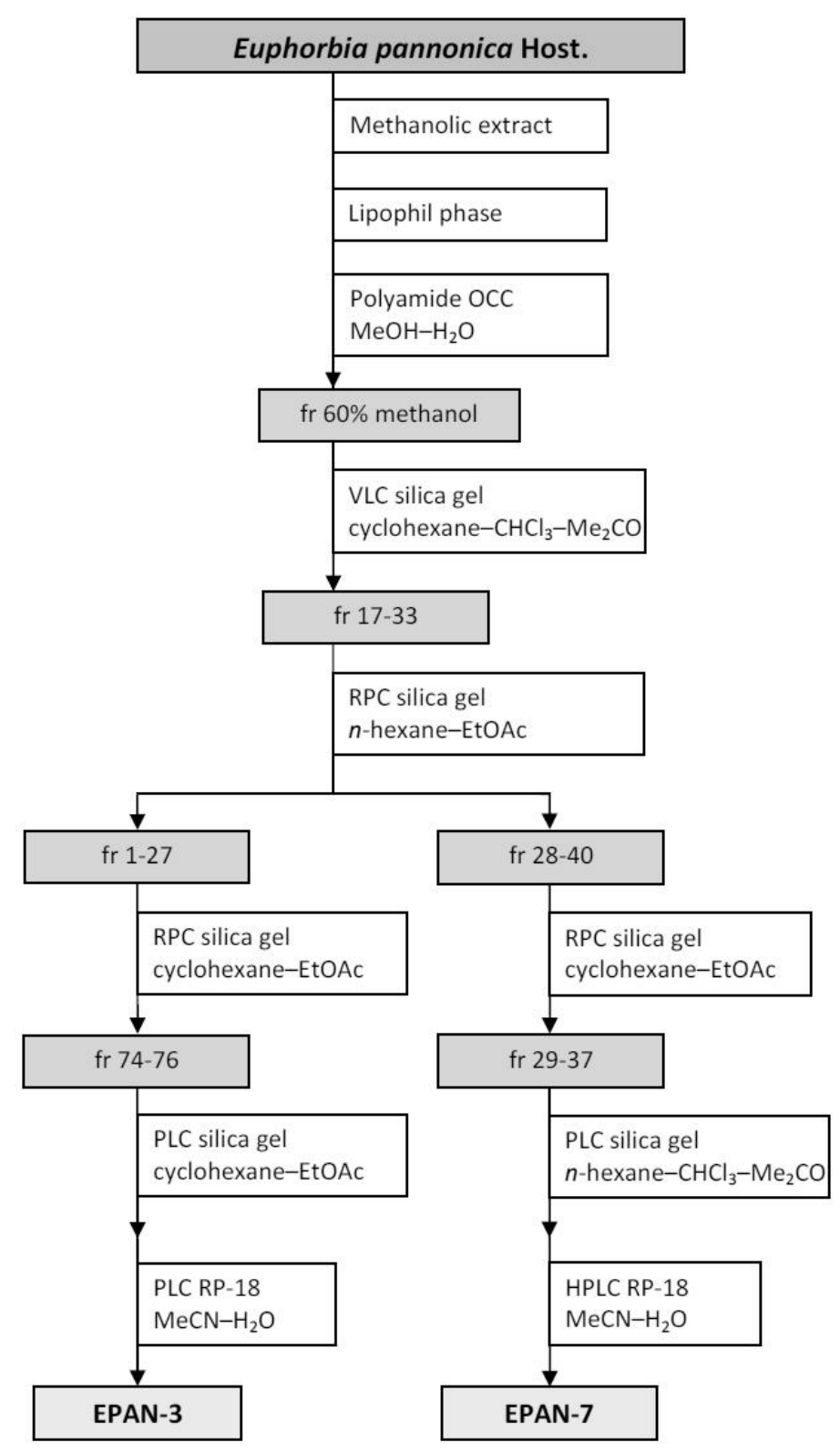

Figure 3. Isolation of diterpenes from E. pannonica

\subsubsection{Isolation of diterpenes from E. esula}

The whole fresh plants of $E$. esula $(8 \mathrm{~kg})$ were percolated with $\mathrm{MeOH}$ at room temperature. After concentration under vacuum, the crude extract was diluted with $\mathrm{H}_{2} \mathrm{O}$ and subjected to solvent partitioning to yield a $\mathrm{CH}_{2} \mathrm{Cl}_{2}$-soluble phase and an $\mathrm{H}_{2} \mathrm{O}$-soluble phase (Figure 4). The concentrated dark-green organic phase (90 g) was chromatographed on a polyamide column. The combined fractions $16-37$, obtained with a mixture of $\mathrm{MeOH}-\mathrm{H}_{2} \mathrm{O}(1: 4)$, were subjected to silica gel VLC, using a gradient system of cyclohexane-EtOAc-EtOH (from 9:1:0 to 1:1:1). Fractions 20-23 and 24-30 
(1 $048 \mathrm{mg}$ ) obtained with cyclohexane-EtOAc-EtOH (80:20:1 and 70:30:1) afforded a crystalline material upon standing, which was recrystallized from MeOH to yield EUP-13 [(10), $105 \mathrm{mg}$. Combined fractions 24-30 were subjected to silica gel RPC, using a gradient system of cyclohexaneEtOAc-EtOH (from 80:20:0.5 to 30:10:1). Fractions 37-48 (102.8 mg) were transferred repeatedly to a silica gel RPC and successively eluted with benzene- $\mathrm{CH}_{2} \mathrm{Cl}_{2}-\mathrm{Et}_{2} \mathrm{O}$ (from 2:1:0.5 to 1:1:2). From fractions 25-28, obtained with benzene- $\mathrm{CH}_{2} \mathrm{Cl}_{2}-\mathrm{Et}_{2} \mathrm{O}$ (2:1:1), $11.8 \mathrm{mg}$ of EUP-23 (7) was obtained as crystals, and from fractions 29-41, eluted with benzene- $\mathrm{CH}_{2} \mathrm{Cl}_{2}-\mathrm{Et}_{2} \mathrm{O}(2: 1: 1)$, the yield of EUP-20 (3) was $5.7 \mathrm{mg}$.

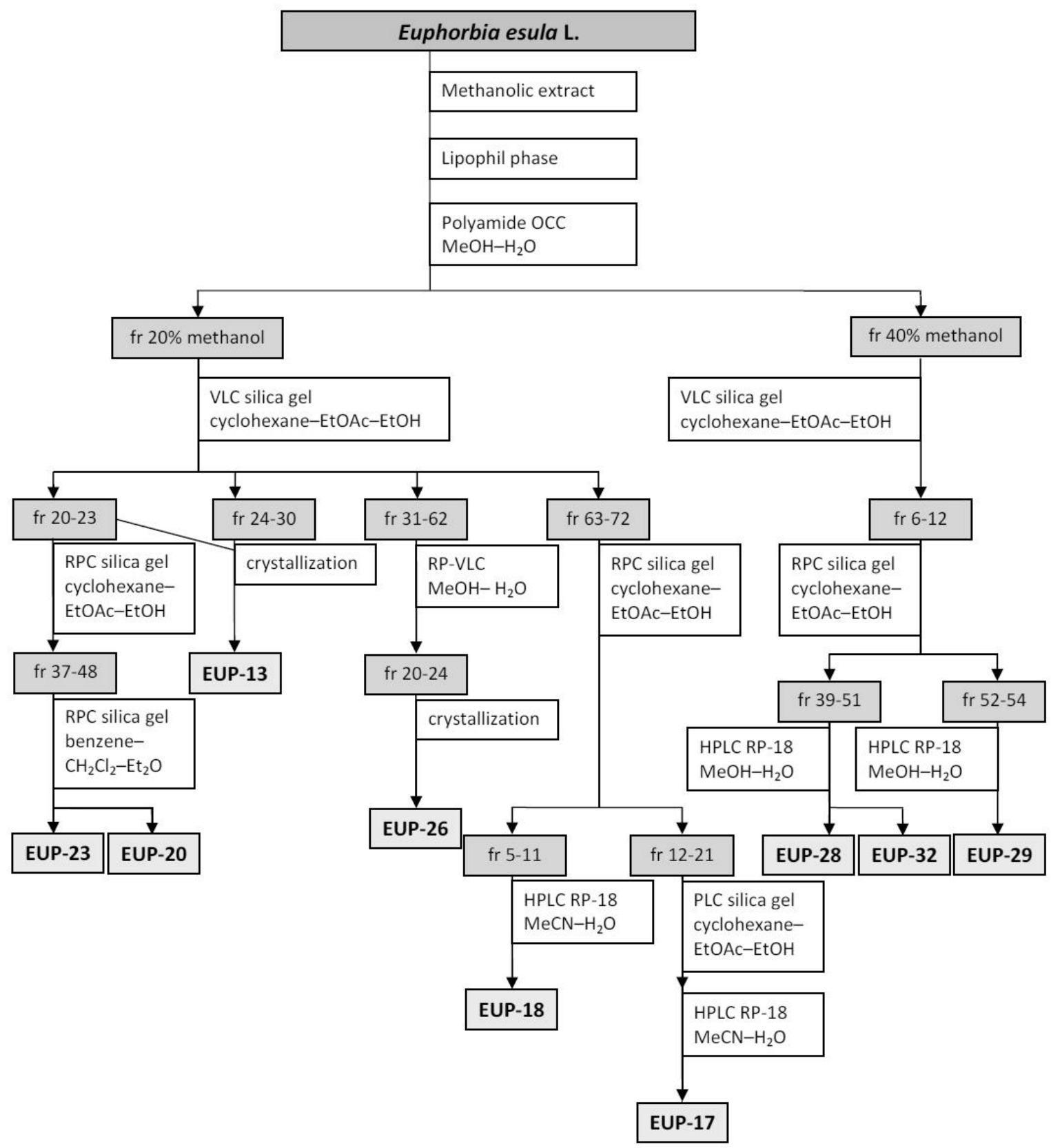

Figure 4. Isolation of diterpenes from E. esula 
Fractions 31-62 (2.835 g) were fractionated by RP-VLC, using a gradient system of $\mathrm{MeOH}-\mathrm{H}_{2} \mathrm{O}$ (from 3:2 to 1:0). From the resulting fractions $20-24\left(1022.3 \mathrm{mg}\right.$ ) on elution with $\mathrm{MeOH}-\mathrm{H}_{2} \mathrm{O}(7: 3)$, EUP-26 [(9), $10.0 \mathrm{mg}]$ was crystallized.

Fractions 63-72 (0.966 g) were subjected to silica gel RPC, using a gradient system of cyclohexane-EtOAc-EtOH (from 1:1:0 to 1:1:1). Fractions from cyclohexane-EtOAc (1:1), 5-11 (82.4 $\mathrm{mg}$ ) and 12-21 $(55.1 \mathrm{mg})$, were further fractionated. Fractions 5-11 were eluted by RP-HPLC with $\mathrm{MeCN}-\mathrm{H}_{2} \mathrm{O}(6: 4)$ as eluent at a flow rate of $1.0 \mathrm{~mL} / \mathrm{min}$. Purification of the compound observed at $t_{\mathrm{R}}=11.4 \mathrm{~min}$ yielded EUP-18 [(6), $3.9 \mathrm{mg}$. Fractions $12-21$ were further purified by preparative TLC on silica gel, using cyclohexane-EtOAc-EtOH (5:5:2) as solvent, and followed by HPLC, using a RP column and $\mathrm{MeCN}-\mathrm{H}_{2} \mathrm{O}(6: 4)$ as eluent, to yield $30 \mathrm{mg}$ of EUP-17 (11).

The combined fractions 38-44 (2.600 g) obtained from the polyamide column with $\mathrm{H}_{2} \mathrm{O}-\mathrm{MeOH}$ (3:2) were subjected to silica gel VLC, using a gradient system of cyclohexane-EtOAc-EtOH (from 30:10:1 to 5:5:4). The resulting fractions 6-12 $(817.3 \mathrm{mg})$, eluted with cyclohexane-EtOAc-EtOH (30:10:1), were subjected to silica gel RPC, using a gradient system of cyclohexane-EtOAc-EtOH (from 40:10:0 to 30:10:1). Fractions 39-51 $(34.5 \mathrm{mg}$ ) and 52-54 $(89.6 \mathrm{mg})$ were obtained with the 70:20:2 and 30:10:1 eluents. These fractions were further chromatographed by RP-HPLC, using $\mathrm{MeOH}-\mathrm{H}_{2} \mathrm{O}(7: 3)$ as eluent at a flow rate of $3.0 \mathrm{~mL} / \mathrm{min}$. The compounds observed at $t_{\mathrm{R}}$ of $23.7 \mathrm{~min}$, $26.1 \mathrm{~min}$ and $35.4 \mathrm{~min}$ yielded EUP-28 [(4), $17.6 \mathrm{mg}$ ], EUP-32 [(5), $5.2 \mathrm{mg}$ ] and EUP-29 [(8), $25.0 \mathrm{mg}$, respectively.

\subsubsection{Isolation of diterpenes from E. falcata}

The fresh plant material $(20 \mathrm{~kg})$, which was stored at $-20^{\circ} \mathrm{C}$ before processing, was crushed in a blender and then percolated with $\mathrm{MeOH}(178 \mathrm{~L})$ at room temperature. The crude extract was concentrated in vacuum and subjected to solvent-solvent partitioning with $\mathrm{CHCl}_{3}$ (30 L) (Figure 5). On evaporation, an organic phase residue of $344 \mathrm{~g}$ was obtained, which was chromatographed on a polyamide column (1 $100 \mathrm{~g}$ ) with mixtures of $\mathrm{H}_{2} \mathrm{O}-\mathrm{MeOH}(3: 2,2: 3$ and 1:4) as eluents. The fractions obtained with $\mathrm{H}_{2} \mathrm{O}-\mathrm{MeOH}$ (3:2 and 2:3) were combined and subjected to silica gel VLC, using a gradient system of cyclohexane-EtOAc-MeOH (from 8:2:0 to 0:0:1). The OCC fractions were combined into 6 fractions according to the TLC monitoring.

From fractions 9-14 (0.49 g), obtained with cyclohexane-EtOAc-MeOH (7:3:0), EFAL-3 (12) was crystallized. It was further purified on NP-TLC, using $n$-hexane-Me $\mathrm{C}_{2} \mathrm{CO}(7: 3)$, to yield $24.8 \mathrm{mg}$ of EFAL-3. The mother liquor of compound EFAL-3 was subjected to RPC, eluted with cyclohexane$\mathrm{CH}_{2} \mathrm{Cl}_{2}-\mathrm{MeOH}$ of increasing polarity (from 80:20:1 to 60:50:3; layer thickness: $2 \mathrm{~mm}$, flow rate: 7 $\mathrm{mL} / \mathrm{min}$ ). Fractions 58-67 (148.9 mg), eluted with cyclohexane- $\mathrm{CH}_{2} \mathrm{Cl}_{2}-\mathrm{MeOH}$ (60:30:2), were further separated on RP-VLC with $\mathrm{MeOH}-\mathrm{H}_{2} \mathrm{O}$ (from 1:1 to 85:15). Fractions 25-26 (25.6 mg) obtain- 


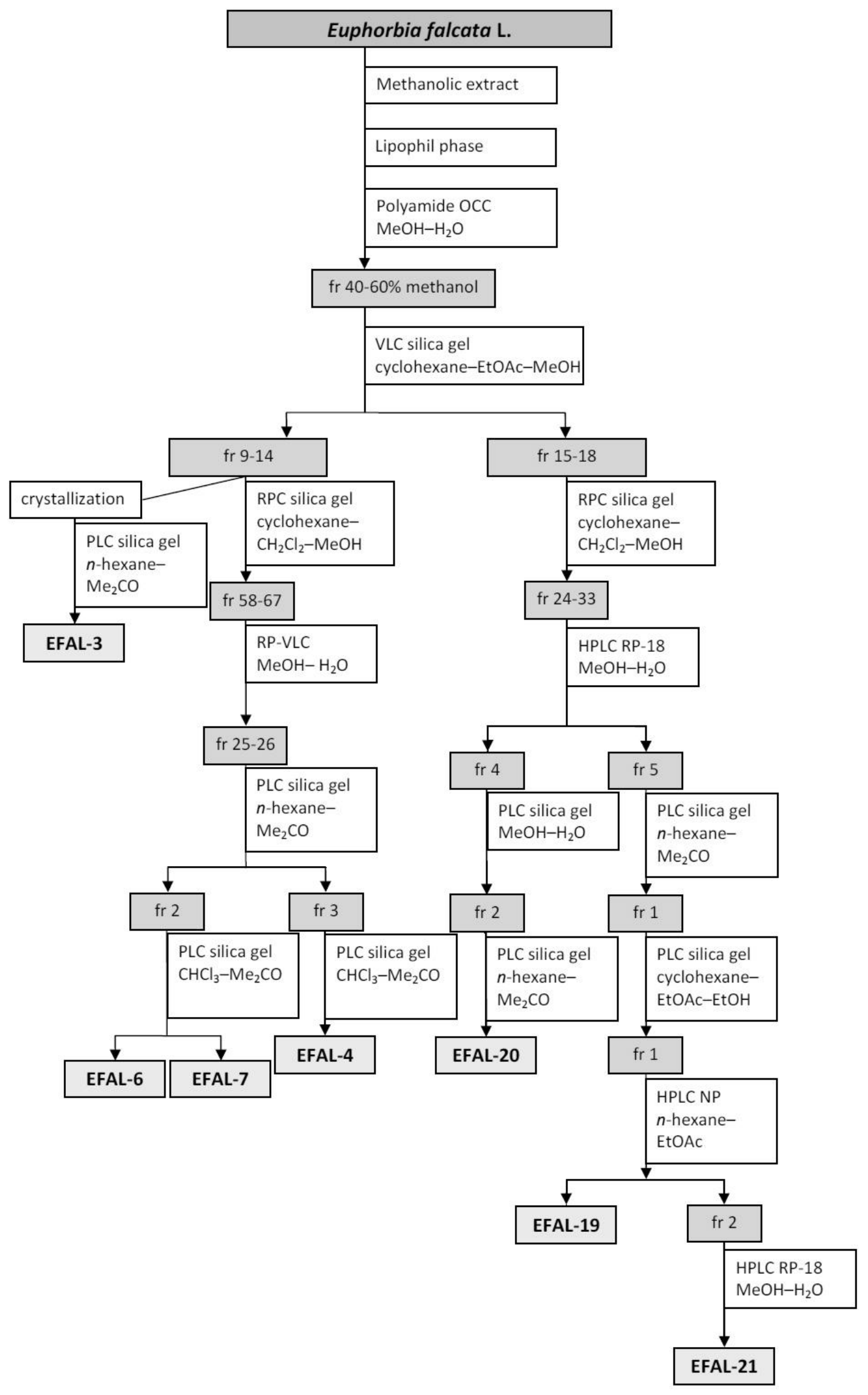

Figure 5. Isolation of diterpenes from E. falcata 
ed with $\mathrm{MeOH}-\mathrm{H}_{2} \mathrm{O}(4: 1)$ were purified by preparative NP-TLC, with $n$-hexane- $\mathrm{Me}_{2} \mathrm{CO}$ (3:2) as developing system, and finally by preparative NP-TLC with $\mathrm{CHCl}_{3}-\mathrm{Me}_{2} \mathrm{CO}$ (49:1), to yield compounds EFAL-4 [(13), $3.7 \mathrm{mg}]$, EFAL-6 [(14), $3.2 \mathrm{mg}]$ and EFAL-7 [(15), $3.5 \mathrm{mg}]$.

Fractions $15-18(0.98 \mathrm{~g})$ were separated by RPC, using cyclohexane- $\mathrm{CH}_{2} \mathrm{Cl}_{2}-\mathrm{MeOH}$ of increasing polarity as solvent system (from 70:20:1 to 60:50:3; flow rate: $8.4 \mathrm{~mL} / \mathrm{min}$, layer thickness: $4 \mathrm{~mm}$ ). Fractions 24-33 (0.40 g; compositions of the eluent: 70:20:2 and 70:30:2) were purified by preparative RP-HPLC at a flow rate of $2.5 \mathrm{~mL} / \mathrm{min}$, using a gradient $\mathrm{MeOH}-\mathrm{H}_{2} \mathrm{O}$ solvent system $(0-15$ $\min 55: 45,15-25 \min$ by gradation $9: 1,25-40 \min 9: 1,40-45 \min$ by gradation $55: 45,45-65 \min$ 55:45). The fraction (119 mg) at $t_{\mathrm{R}}=31.0 \mathrm{~min}$ was subjected to TLC [MeOH- $\mathrm{H}_{2} \mathrm{O}(9: 1)$ then $n-$ hexane- $\left.\mathrm{Me}_{2} \mathrm{CO}(7: 3)\right]$ to afford EFAL-20 [(17), $\left.10.6 \mathrm{mg}\right]$. The fraction $(67 \mathrm{mg})$ at $t_{\mathrm{R}}=32.0 \mathrm{~min}$ was purified by NP-TLC $[n$-hexane-Me $2 \mathrm{CO}$ (7:3), then cyclohexane-EtOAc-EtOH (70:30:1)]. It was then separated by NP-HPLC at a flow rate of $1 \mathrm{~mL} / \mathrm{min}$, using $n$-hexane-Me ${ }_{2} \mathrm{CO}(7: 3)$ as solvent system, to yield $4.9 \mathrm{mg}$ of EFAL-19 [(16), $\left.t_{\mathrm{R}}=11.4 \mathrm{~min}\right]$. The fraction $(7.5 \mathrm{mg})$ at $t_{\mathrm{R}}=12.4 \mathrm{~min}$ was further chromatographed by RP-HPLC at a flow rate of $0.5 \mathrm{~mL} / \mathrm{min}$, using $\mathrm{MeOH}-\mathrm{H}_{2} \mathrm{O}$ (3:1), and the compound at $t_{\mathrm{R}}=35.0 \mathrm{~min}$ was isolated as EFAL-21 [(18), $\left.4.8 \mathrm{mg}\right]$. 


\subsection{Characterization and structure determination of the isolated compounds}

The structure elucidation was performed by means of NMR and mass spectroscopy (MS). Table 1 lists some physical characteristics for the isolated compounds, such as optical rotation data and melting points.

Table 1. Yields and physical data on the isolated compounds

\begin{tabular}{|c|c|c|c|c|}
\hline \multirow{2}{*}{$\begin{array}{l}\text { Compound } \\
\text { EPAN-3 (1) }\end{array}$} & \multirow{2}{*}{$\begin{array}{r}\text { Yield (mg) } \\
4.2\end{array}$} & \multicolumn{2}{|c|}{ Optical rotation $\left[{ }^{\circ}(t)(c)\right]$} & \multirow{2}{*}{$\begin{array}{l}\text { M.p. }\left({ }^{\circ} \mathrm{C}\right) \\
-\end{array}$} \\
\hline & & $-20\left(t_{1}\right)$ & $(0.04)$ & \\
\hline EPAN-7 (2) & 3.6 & No Data & & - \\
\hline EUP-13 (10) & 105.0 & $+5\left(t_{2}\right)$ & $(0.1)$ & $262-268$ \\
\hline EUP-17 (11) & 30.0 & $-101\left(t_{2}\right)$ & $(0.12)$ & $134-138$ \\
\hline EUP-18 (6) & 3.9 & $-140\left(t_{3}\right)$ & $(0.1)$ & - \\
\hline EUP-20 (3) & 5.7 & $-4\left(t_{3}\right)$ & $(0.1)$ & - \\
\hline EUP-23 (7) & 11.8 & $-82\left(t_{3}\right)$ & $(0.1)$ & - \\
\hline EUP-26 (9) & 10.0 & $-10\left(t_{4}\right)$ & (0.175; MeOH) & - \\
\hline EUP-28 (4) & 17.6 & $-152\left(t_{3}\right)$ & $(0.1)$ & $212-215$ \\
\hline EUP-29 (8) & 25.0 & $-42\left(t_{3}\right)$ & $(0.1)$ & - \\
\hline EUP-32 (5) & 5.2 & $-113\left(t_{3}\right)$ & $(0.1)$ & - \\
\hline EFAL-3 (12) & 24.8 & $-68\left(t_{5}\right)$ & $(0.1)$ & $165-167$ \\
\hline EFAL-4 (13) & 3.7 & $-4\left(t_{5}\right)$ & $(0.1)$ & - \\
\hline EFAL-6 (14) & 3.2 & $-31\left(t_{5}\right)$ & $(0.05)$ & - \\
\hline EFAL-7 (15) & 3.5 & $-35\left(t_{5}\right)$ & $(0.1)$ & - \\
\hline EFAL-19 (16) & 4.9 & $+60\left(t_{2}\right)$ & $(0.1)$ & - \\
\hline EFAL-20 (17) & 10.6 & $+60\left(t_{2}\right)$ & $(0.1)$ & $225-228$ \\
\hline EFAL-21 (18) & 4.8 & $+59\left(t_{2}\right)$ & $(0.1)$ & $126-128$ \\
\hline
\end{tabular}

The most useful data regarding the chemical structures of the compounds were obtained from advanced 1D and 2D NMR experiments, including ${ }^{1} \mathrm{H}$ NMR, JMOD, ${ }^{1} \mathrm{H}-{ }^{1} \mathrm{H}$ COSY, NOESY, HSQC and HMBC spectroscopy.

The high-resolution MS measurements revealed the exact masses and molecular compositions of the compounds (Table 2). The fragment ions observed indicated the sequential loss of esterifying acids (acetic, benzoic, nicotinic and isobutanoic acids) from the parent ions. 
Table 2. MS data on the isolated new compounds

\begin{tabular}{|c|c|c|c|}
\hline Compound & M.W. & MS & MS fragments $(m / z)$ \\
\hline \multirow[t]{2}{*}{ EPAN-3 (1) } & \multirow[t]{2}{*}{506} & ESIMS & $\begin{array}{l}529[\mathrm{M}+\mathrm{Na}]^{+}, 507[\mathrm{M}+\mathrm{H}]^{+}, 385\left[\mathrm{M}+\mathrm{H}-\mathrm{C}_{6} \mathrm{H}_{5} \mathrm{COOH}\right]^{+}, 297[385- \\
\left.\mathrm{C}_{3} \mathrm{H}_{7} \mathrm{COOH}\right]^{+}\end{array}$ \\
\hline & & HREIMS & $384.2304\left[\mathrm{M}-\mathrm{C}_{6} \mathrm{H}_{5} \mathrm{COOH}\right]^{+}$(calcd. for $\mathrm{C}_{24} \mathrm{H}_{32} \mathrm{O}_{4}, 384.2301$ ) \\
\hline EPAN-7 (2) & 520 & HREIMS & $520.2829[\mathrm{M}]^{+}$(calcd. for $\mathrm{C}_{32} \mathrm{H}_{40} \mathrm{O}_{6}, 520.2825$ ) \\
\hline EUP-18 (6) & 762 & HRESIMS & $\begin{array}{l}\left.763.3075[\mathrm{M}+\mathrm{H}]^{+} \text {(calcd for } \mathrm{C}_{40} \mathrm{H}_{47} \mathrm{O}_{13} \mathrm{~N}_{2}, 763.3073\right), 640[(\mathrm{M}+ \\
\left.\mathrm{H})-\mathrm{C}_{6} \mathrm{H}_{5} \mathrm{NO}_{2}\right]^{+}, 580[640-\mathrm{ACOH}]^{+}, 598\left[640-\mathrm{CH}_{2} \mathrm{CO}\right]^{+}, 538 \\
{\left[598-\mathrm{CH}_{3} \mathrm{COOH}\right]^{+}, 478\left[538-\mathrm{CH}_{3} \mathrm{COOH}\right]^{+}, 418[478-} \\
\left.\mathrm{CH}_{3} \mathrm{COOH}\right]^{+}, 312\left[(\mathrm{M}+\mathrm{H})-\mathrm{C}_{6} \mathrm{H}_{5} \mathrm{NO}_{2}-4 \times \mathrm{CH}_{3} \mathrm{COOH}-\right. \\
\left.\left(\mathrm{CH}_{3}\right)_{2} \mathrm{CHCOOH}\right]^{+}, 295\left[312-\mathrm{H}_{2} \mathrm{O}\right]^{+}\end{array}$ \\
\hline EUP-20 (3) & 798 & HRESIMS & $821.3204[\mathrm{M}+\mathrm{Na}]^{+}$(calcd for $\left.\mathrm{C}_{38} \mathrm{H}_{54} \mathrm{O}_{18} \mathrm{Na}, 821.3208\right)$. \\
\hline EUP-23 (7) & 727 & HRESIMS & $\begin{array}{l}728.3264[\mathrm{M}+\mathrm{H}]^{+}\left(\mathrm{calcd} \text { for } \mathrm{C}_{38} \mathrm{H}_{50} \mathrm{O}_{13} \mathrm{~N}, 728.3277\right), 626[686- \\
\mathrm{AcOH}]^{+}, 566[626-\mathrm{AcOH}]^{+}, 506[566-\mathrm{AcOH}]^{+}, 418[566- \\
i \mathrm{BuOH}]^{+}, 295[418-\mathrm{NicOH}]^{+}\end{array}$ \\
\hline EUP-28 (4) & 654 & HRESIMS & $\begin{array}{l}\left.677.2554[\mathrm{M}+\mathrm{Na}]^{+} \text {(calcd for } \mathrm{C}_{35} \mathrm{H}_{42} \mathrm{O}_{12} \mathrm{Na}, 677.2568\right), 672[\mathrm{M} \\
\left.+\mathrm{NH}_{4}\right]^{+}, 473[533-\mathrm{AcOH}]^{+}, 413[473-\mathrm{AcOH}]^{+}, 353[413- \\
\mathrm{AcOH}]^{+}, 293[353-\mathrm{AcOH}]^{+}\end{array}$ \\
\hline EUP-29 (8) & 669 & HRESIMS & $670.3204[\mathrm{M}+\mathrm{H}]^{+}$(calcd for $\mathrm{C}_{36} \mathrm{H}_{48} \mathrm{O}_{11} \mathrm{~N}, 670.3222$ ) \\
\hline EUP-32 (5) & 562 & HRESIMS & $585.2664[\mathrm{M}+\mathrm{Na}]^{+}$(calcd for $\mathrm{C}_{30} \mathrm{H}_{42} \mathrm{O}_{10} \mathrm{Na}, 585.2675$ ) \\
\hline EFAL-3 (12) & 492 & HRESIMS & $515.2984[\mathrm{M}+\mathrm{Na}]^{+}$(calcd. for $\left.\mathrm{C}_{28} \mathrm{H}_{44} \mathrm{O}_{7} \mathrm{Na}, 515.2985\right)$ \\
\hline EFAL-4 (13) & 654 & HRESIMS & $677.2935[\mathrm{M}+\mathrm{Na}]^{+}$(calcd. for $\mathrm{C}_{36} \mathrm{H}_{46} \mathrm{O}_{11} \mathrm{Na}, 677.2938$ ) \\
\hline EFAL-6 (14) & 626 & HRESIMS & $649.2999[\mathrm{M}+\mathrm{Na}]^{+}$(calcd. for $\mathrm{C}_{35} \mathrm{H}_{46} \mathrm{O}_{10} \mathrm{Na}, 649.2989$ ) \\
\hline EFAL-7 (15) & 712 & HRESIMS & $735.2989[\mathrm{M}+\mathrm{Na}]^{+}$(calcd. for $\mathrm{C}_{38} \mathrm{H}_{48} \mathrm{O}_{13} \mathrm{Na}, 735.2993$ ) \\
\hline EFAL-19 (16) & 840 & HRESIMS & $863.3473[\mathrm{M}+\mathrm{Na}]^{+}$(calcd. for $\left.\mathrm{C}_{44} \mathrm{H}_{56} \mathrm{O}_{16} \mathrm{Na}, 863.3466\right)$ \\
\hline EFAL-21 (18) & 826 & HRESIMS & $849.3307[\mathrm{M}+\mathrm{Na}]^{+}$(calcd. for $\mathrm{C}_{43} \mathrm{H}_{54} \mathrm{O}_{16} \mathrm{Na}, 849.3310$ ) \\
\hline
\end{tabular}

EPAN-3

The molecular formula of EPAN-3 (1) was assigned as $\mathrm{C}_{24} \mathrm{H}_{32} \mathrm{O}_{4}$ via ESIMS, HREIMS and NMR investigations. The ${ }^{1} \mathrm{H}$ NMR, JMOD and HSQC spectra of EPAN-3 suggested a diterpene skeleton with 20 carbon atoms ( 4 methyls, 3 methylenes, 7 methine groups and 6 quaternary carbons) and typical signals for 1 benzoyl and 1 isobutanoyl group. The carbon and proton signals exhibited 2 olefin groups (C-1, C-2 and C-6, C-7) at $\delta_{\mathrm{C}} 160.2,136.8,136.6$ and $131.6 \mathrm{ppm}$ and at $\delta_{\mathrm{H}} 7.57$ and $5.66 \mathrm{ppm}$. The signal at $\delta_{\mathrm{C}} 210.0$ revealed 1 keto group (C-3) and those at $\delta_{\mathrm{C}} 69.8$ and $\delta_{\mathrm{H}} 4.721$ isolated $O$ - 
substituted methylene group ( $\mathrm{C}-20)$. A broad singlet at $\delta_{\mathrm{H}} 5.5$ identified a hydroxy group (9-OH). 3 spin systems of correlated protons were identified by means of the gradient COSY spectrum: $=\mathrm{CH}-$ $\mathrm{CH}-\mathrm{CH}-\mathrm{CH}_{2}-\left(\delta_{\mathrm{H}} 7.57,3.32,2.46,2.93\right.$ and 2.22$),=\mathrm{CH}-\mathrm{CH}-\mathrm{CH}-\left(\delta_{\mathrm{H}} 5.66,2.16\right.$ and 0.83$)$ and $\mathrm{CH}\left(\mathrm{CH}_{3}\right)-\mathrm{CH}_{2}-\left(\delta_{\mathrm{H}} 1.43,0.92\right.$ and $\left.2.13 / 1.55\right)$. Tertiary methyls and quaternary carbons joined these structural moieties. The correlations of the HMBC spectrum confirmed these assignments. The chemical shifts $\delta_{\mathrm{C}} 62.8$ and 69.8 showed $O$-substitutions on C-13 and C-20. The binding of the benzoyl group at C-20 was indicated by at the HMBC correlation of the signals at $\delta_{\mathrm{C}} 166.2$ and $\delta_{\mathrm{H}}$ 4.72. The position of the hydroxy group was deduced on the basis of biogenetic considerations and literature data on structurally related compounds. A NOESY experiment demonstrated the relative configuration of the stereogenic centres of EPAN-3. The 8 position of the $\mathrm{H}-56, \mathrm{H}-8, \mathrm{H}-11, \mathrm{H}-12 \mathrm{~B}$ and 17- $\mathrm{CH}_{3}$ protons was revealed by the NOE interactions among these protons. The nuclear Overhauser effects (NOE) between $16-\mathrm{CH}_{3}$ and $\mathrm{H}-14, \mathrm{H}-14$ and 9-OH indicated the $\alpha$ arrangement of all these proton, methyl and hydroxy groups.

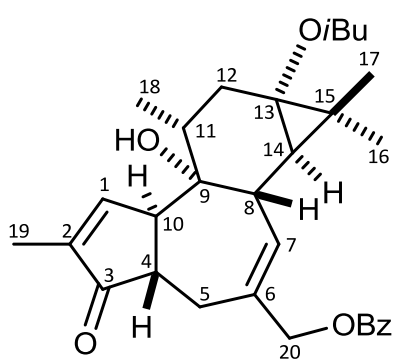

1

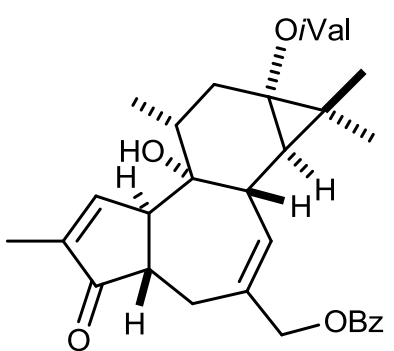

2

EPAN-7

EPAN-7 (2), a colourless oil, has the molecular formula $\mathrm{C}_{32} \mathrm{H}_{40} \mathrm{O}_{6}$, determined via the quasimolecular ion peak at $m / z 520.2829[\mathrm{M}]^{+}$in the HREIMS and supported by the hydrogen and carbon atom counts in the NMR spectra. The ${ }^{1} \mathrm{H}$ NMR and JMOD spectra proved closely comparable to those of EPAN-3; the dissimilarity is an isovaleroyl ester group instead of an isobutanoyl on C-13 in EPAN-7.

EUP-20

EUP-20 (3, esulatin H), obtained as an amorphous solid with the molecular formula $\mathrm{C}_{38} \mathrm{H}_{54} \mathrm{O}_{18}$, was shown on the basis of a detailed NMR study to be a polyacylated derivative of a jatrophane compound. Seven acetate groups $\left[\delta_{\mathrm{H}} 2.27 \mathrm{~s}, 2.24 \mathrm{~s}, 2.20 \mathrm{~s}, 2.15 \mathrm{~s}, 2 \times 2.13 \mathrm{~s}\right.$ and $1.80 \mathrm{~s} ; \delta_{\mathrm{c}} 170.7,3 \times$ 170.3 and $3 \times 169.5(\mathrm{CO})$ and $22.7,22.5,22.0,21.5,2 \times 21.2$ and $\left.20.5\left(\mathrm{CH}_{3}\right)\right]$ and 1 isobutanoyl group $\left(\delta_{\mathrm{H}} 2.60 \mathrm{~m}, 1.25 \mathrm{~d}\right.$ and $1.24 \mathrm{~d} ; \delta_{\mathrm{C}} 176.1,34.6,19.5$ and 18.5$)$ were proved by the ${ }^{1} \mathrm{H}$ and ${ }^{13} \mathrm{C} \mathrm{NMR}$ spectra. Four methyl signals $(1.67 \mathrm{~s}, 1.44 \mathrm{~d}, 1.40 \mathrm{~s}$ and $0.95 \mathrm{~s})$ were observed in the ${ }^{1} \mathrm{H}$ NMR spectrum. The ${ }^{1} \mathrm{H}$ NMR, JMOD and HSQC spectra of EUP-20 reflected a skeleton consisting of 20 carbons (4 methyls, 2 methylenes, 9 methines and 5 quaternary carbons). The signal at $\delta_{\mathrm{H}} 7.39 \mathrm{~s}$, 
which showed no correlation in the HSQC spectrum to any carbon, was assigned to a hydroxy group (14-OH). From the ${ }^{1} \mathrm{H}-{ }^{1} \mathrm{H}$ COSY and HSQC spectra of EUP-20, 3 sequences of correlated hydrogen atoms could be extracted, $-\mathrm{CHR}-\mathrm{CH}-\mathrm{CHR}-\left(\delta_{\mathrm{H}} 5.80,4.58\right.$ and 6.38$),-\mathrm{CHR}-\mathrm{CHR}-\mathrm{CHR}-\left(\delta_{\mathrm{H}} 7.23,6.30\right.$ and 5.41) and $-\mathrm{CH}-\mathrm{CHR}-\mathrm{CH}\left(\mathrm{CH}_{3}\right)-\left(\delta_{\mathrm{H}} 3.80,5.80,2.98\right.$ and 1.44), and 1 exomethylene group $\left(\delta_{\mathrm{H}} 6.39\right.$ $\mathrm{s}$ and $6.06 \mathrm{~s}, \delta_{\mathrm{c}}$ 123.5). These fragments, tertiary methyls and quaternary carbons were connected by means of an HMBC experiment. The positions of the ester groups were also established via the HMBC spectra and the literature data on structurally analogous compounds. The relative configuration of EUP-20 was determined via a NOESY experiment. As reference point, the position of $\mathrm{H}-4$, was chosen to be $\alpha$. NOEs between hydrogen pairs $\mathrm{H}-4 / \mathrm{H}-3, \mathrm{H}-4 / \mathrm{H}-7, \mathrm{H}-4 / \mathrm{OH}-14, \mathrm{OH}-14 / 13-$ $\mathrm{CH}_{3}, \mathrm{H}-20 / \mathrm{H}-1 \alpha$ and $\mathrm{H}-7 / 10-\mathrm{CH}_{3}(\mathrm{C}-19)$ were indicative of the $\alpha$ orientation of these hydrogen atoms. NOEs between hydrogen pairs $10-\mathrm{CH}_{3}(\mathrm{C}-18) / \mathrm{H}-9, \mathrm{H}-9 / \mathrm{H}-8, \mathrm{H}-9 / \mathrm{H}-11, \mathrm{H}-11 / \mathrm{H}-12, \mathrm{H}-12 / \mathrm{H}-8, \mathrm{H}-12 / \mathrm{H}-$ $13, \mathrm{H}-16 / \mathrm{H}-16$ required their $\mathbf{B}$ position. All of the above evidence proved the structure 3 for EUP-20.

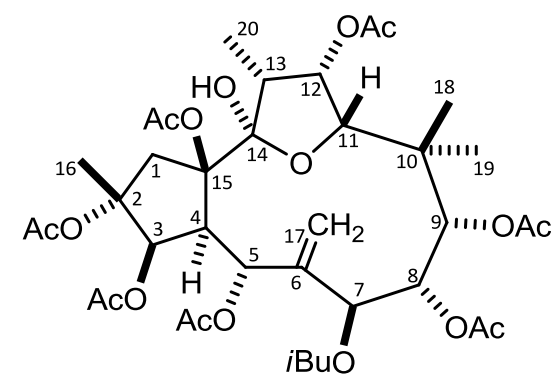

3

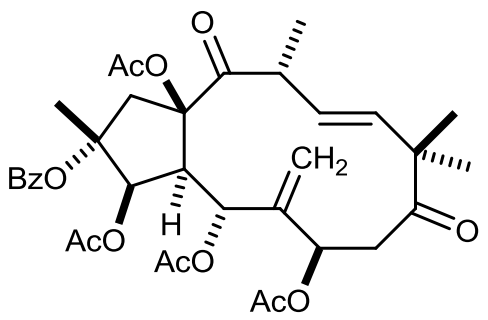

4

EUP-28

EUP-28 (4, esulatin I) was isolated as white crystals with the molecular formula $\mathrm{C}_{35} \mathrm{H}_{42} \mathrm{O}_{12}$. From the ${ }^{1} \mathrm{H}$ NMR and JMOD spectra, 5 ester residues were identified as 1 benzoate $\left(\delta_{\mathrm{H}} 8.11,7.40\right.$ and $7.53 ; \delta_{\mathrm{C}}$ $165.6,131.1,130.0,128.1$ and 132.6$)$ and 4 acetate $\left[\delta_{H} 2.21,2.18,2.15\right.$ and $2.07 ; \delta_{C} 170.2,169.9$, 169.6 and $169.2(\mathrm{CO})$ and $22.9,21.4,20.7$ and $20.1\left(\mathrm{CH}_{3}\right)$ ] groups. The diterpene core was found to contain 4 methyls, 3 methylenes, 7 methines, 6 quaternary carbons and 2 keto functions $\left(\delta_{\mathrm{c}} 209.3\right.$ and 209.5). The ${ }^{1} \mathrm{H}-{ }^{1} \mathrm{H}$ COSY of EUP-28 revealed the presence of the structural fragments $-\mathrm{CH}_{2}-\mathrm{CR}-$ $\mathrm{CH}-\mathrm{CH}-\mathrm{CH}-\mathrm{C}\left(=\mathrm{CH}_{2}\right)-\mathrm{CH}-\mathrm{CH}_{2}-(-\mathrm{C}-1-(\mathrm{C}-17)-\mathrm{C}-8-)$, and $-\mathrm{CH}=\mathrm{CH}-\mathrm{CH}\left(\mathrm{CH}_{3}\right)-(-\mathrm{C}-11-\mathrm{C}-13(\mathrm{C}-20)-)$. Their connectivities were determined from the long-range $\mathrm{C}-\mathrm{H}$ correlations observed in the HMBC spectrum. The relative configuration of EUP-28 was established on the basis of the NOESY correlations between $\mathrm{H}-4 / \mathrm{H}-1 \alpha, \mathrm{H}-4 / \mathrm{H}-2^{\prime}, 6^{\prime}, \mathrm{H}-4 / \mathrm{H}-7, \mathrm{H}-7 / \mathrm{H}-12, \mathrm{H}-12 / \mathrm{H}-20, \mathrm{H}-12 / \mathrm{H}-19$ and $\mathrm{H}-86 / \mathrm{H}-$ $11, \mathrm{H}-11 / \mathrm{H}-13, \mathrm{H}-13 / \mathrm{H}-5, \mathrm{H}-5 / \mathrm{H}-11, \mathrm{H}-88 / \mathrm{H}-18$ and $\mathrm{H}-11 / \mathrm{H}-18$, thereby confirming structure 4 for EUP-28. 
EUP-32

EUP-32 (5, esulatin J) was obtained as a colourless, amorphous solid. The ${ }^{1} \mathrm{H}$ NMR and JMOD spectra of EUP-32 revealed 3 acetyls and 1 isobutanoyl group. The ${ }^{1} \mathrm{H}$ NMR and JMOD spectra of esulatin J were very similar to those of esulatin I, except for the appearance of an $\mathrm{H}-2$ signal and a change in the chemical shift of C-2 ( $\delta_{\mathrm{C}} 38.3$ in EUP-32, 87.2 in EUP-28). From the COSY, HSQC and HMBC analysis of EUP-32, it was apparent that esulatin I and J are based on the same parent system and differ only in the substituents on C-2 and C-7. The absence of acetyl and benzoyl signals and the appearance of signals of a further isobutanoyl indicated the replacement of one of the acetyl residues with an isobutanoyl group. Comparison of the NOESY spectra of EUP-28 and EUP-32 showed the same relative configuration for these compounds.

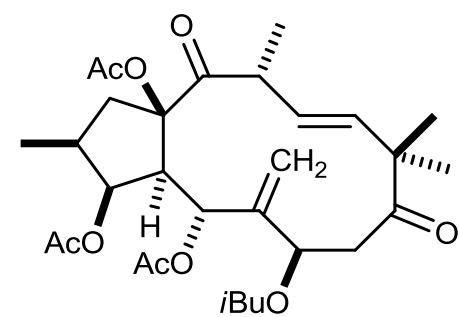

5

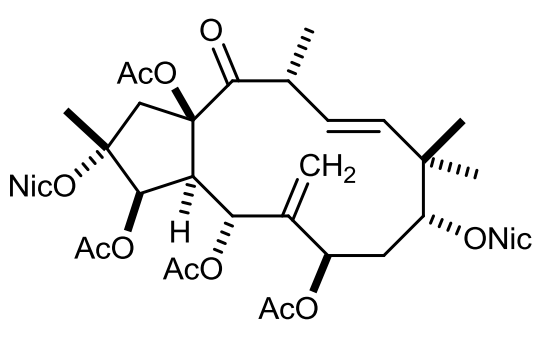

6

EUP-18

EUP-18 (6, esulatin $\mathrm{K}$ ), with molecular formula $\mathrm{C}_{40} \mathrm{H}_{46} \mathrm{O}_{13} \mathrm{~N}_{2}$, was isolated as an amorphous solid. The ${ }^{1} \mathrm{H}$ NMR and JMOD spectra showed characteristic signals for 2 nicotinoyl $\left(\delta_{\mathrm{H}} 9.31,8.44,7.37\right.$ and 8.77; 9.18, 8.13, 7.30, 8.77; $\delta_{\mathrm{c}} 164.1,151.2,125.8,137.5,123.3,152.9 ; 164.3,150.9,127.4,136.7$, 123.5 and 153.6) and 4 acetyl $\left[\delta_{\mathrm{H}} 2.19,2.18,2.16\right.$ and 1.52; $\delta_{\mathrm{C}} 168.8,169.5,169.6$ and 170.3 (CO) and 20.4, 21.1 and $2 \times 21.3\left(\mathrm{CH}_{3}\right)$ ] groups. Examination of the 2D NMR data on EUP-18 revealed that it was based on the same parent system as esulatin $\mathrm{H}$ and $\mathrm{I}$, with differences in the esterification pattern: in the case of EUP-18, the 9-keto group was replaced by a nicotinoyl substituent. The relative configuration of esulatin $\mathrm{K}$ was determined by a NOESY experiment. The NOEs between $\mathrm{H}-$ $4 / \mathrm{H}-1 \alpha, \mathrm{H}-4 / \mathrm{H}-3, \mathrm{H}-4 / \mathrm{H}-7$ and $\mathrm{H}-7 / \mathrm{H}-18$ indicated the $\alpha$-orientation of these protons. The crosspeaks of 6 -oriented protons could be observed between $\mathrm{H}-16 / \mathrm{H}-16, \mathrm{H}-5 / \mathrm{H}-13, \mathrm{H}-13 / \mathrm{H}-11, \mathrm{H}-11 / \mathrm{H}-9$ and $\mathrm{H}-9 / \mathrm{H}-19$.

EUP-23

EUP-23 (7, esulatin L) was isolated as an amorphous solid. The molecular formula of this compound was determined as $\mathrm{C}_{38} \mathrm{H}_{49} \mathrm{O}_{13} \mathrm{~N}$ by means of HRESIMS. The ${ }^{1} \mathrm{H}$ NMR and JMOD spectra exhibited typical signals for 1 nicotinoyl group $\left(\delta_{\mathrm{H}} 9.20,8.22,7.38\right.$ and 8.78; $\delta_{\mathrm{C}} 164.0,151.1,125.7,137.0$, 123.3 and 153.6) and 4 acetyl $\left[\delta_{\mathrm{H}} 2.18,2.16,2.15\right.$ and 2.13; $\delta_{\mathrm{C}} 170.5,170.2,169.5$ and 168.9 (CO) and 21.3, 21.2, 21.1 and $21.0\left(\mathrm{CH}_{3}\right)$ ] groups. Analysis of the ${ }^{1} \mathrm{H}-{ }^{1} \mathrm{H}$ COSY, HSQC and HMBC spectra 
revealed similarity between esulatin $\mathrm{K}$ and $\mathrm{L}$. The difference was that in EUP-23 the 2-O-nicotinoyl group was replaced by an acetyl group and the 7-O-acetyl group by an isobutanoyl group. The relative configuration of esulatin L, established via a NOESY experiment, was found to be the same as that of EUP-18 and EUP-23.

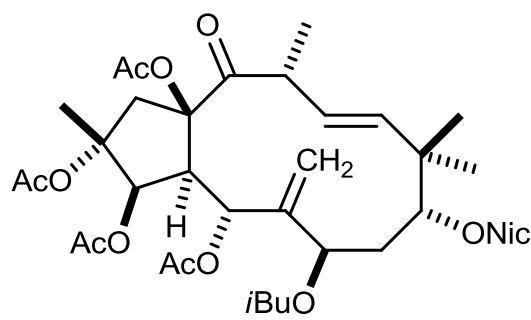

7

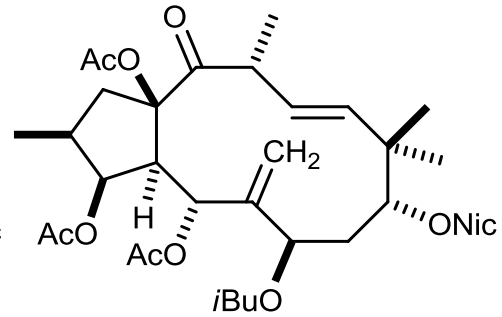

8

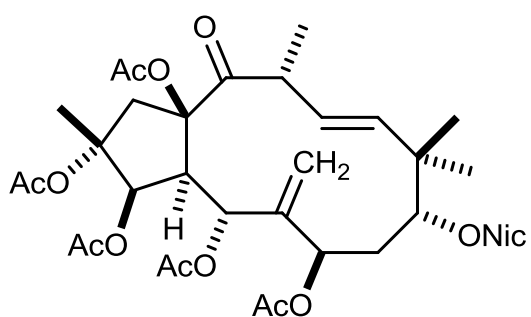

9

EUP-29

EUP-29 (8, esulatin M) was isolated as an amorphous solid with the molecular formula $\mathrm{C}_{36} \mathrm{H}_{47} \mathrm{O}_{11} \mathrm{~N}$. From the ${ }^{1} \mathrm{H}-{ }^{1} \mathrm{H}$ COSY, HSQC, HMBC and NOESY spectra, it was evident that EUP-23 and EUP-29 differ only in the lack of one substituent, an acetyl group on C-2, in esulatin M.

EUP-26

EUP-26 (9) was found to be identical in all of its characteristics, including the ${ }^{1} \mathrm{H}$ and ${ }^{13} \mathrm{C}$ NMR spectral data, with the jatrophane diterpene isolated earlier from Euphorbia peplus. ${ }^{25,121}$

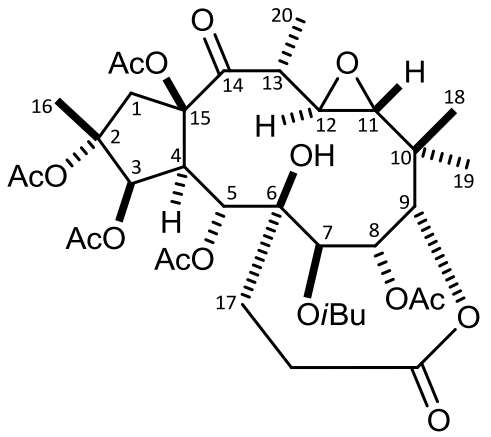

10

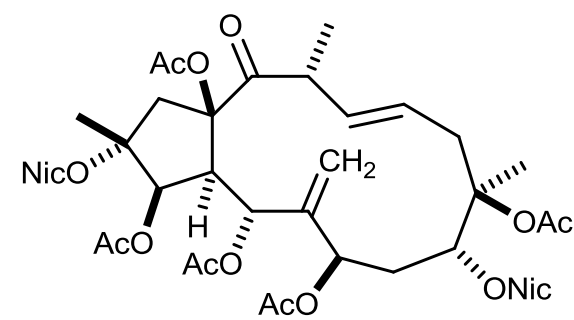

11

EUP-13 and EUP-17

The ${ }^{1} \mathrm{H}$ and ${ }^{13} \mathrm{C}$ NMR spectroscopic investigations proved that EUP-13 (10, salicinolide) was a 17-ethyl bis-homojatrophane-type lactone, salicinolide, and EUP-17 (11, euphosalicine) was the modified jatrophane euphosalicin. Both compounds were described previously from Euphorbia salicifolia. ${ }^{29,30}$

EFAL-3

EFAL-3 (12) was obtained as white crystals. Its molecular formula was determined to be $\mathrm{C}_{28} \mathrm{H}_{44} \mathrm{O}_{7}$. From the ${ }^{1} \mathrm{H}$ NMR and JMOD spectra, 2 ester residues were identified as 1 hexanoyl $\left[\delta_{\mathrm{H}} 2.41(2 \mathrm{H})\right.$, $1.67(2 \mathrm{H}), 1.31(4 \mathrm{H})$, and $0.89(3 \mathrm{H}) ; \delta_{\mathrm{C}} 175.8,34.6,31.3,24.9,22.3$ and 13.9$]$ and 1 acetyl $\left[\delta_{\mathrm{H}} 2.15 ; \delta_{\mathrm{C}}\right.$ 
$170.2(\mathrm{CO})$ and $21.1\left(\mathrm{CH}_{3}\right)$ ] group. Additionally, the ${ }^{1} \mathrm{H}$ NMR spectrum showed signals of 4 methyls $\left(\delta_{H} 1.18,1.05,0.98\right.$ and 0.96$)$. The ${ }^{1} H$ NMR, JMOD and HSQC spectra of EFAL-3 identified a diterpene skeleton containing 20 carbon atoms ( 4 methyls, 4 methylenes, 8 methines and 4 quaternary carbons). The ${ }^{1} \mathrm{H}-{ }^{1} \mathrm{H}$ COSY spectrum indicated 2 structural fragments with correlated protons: $-\mathrm{CH}_{2}-$ $\mathrm{CH}\left(\mathrm{CH}_{3}\right)-\mathrm{CHR}-\mathrm{CH}-\mathrm{CHR}-\left(\delta_{\mathrm{H}} 2.40,1.50,2.18,0.98,5.28,2.60\right.$ and 3.45$)$ and $-\mathrm{CH}_{2}-\mathrm{CH}_{2}-\mathrm{CH}-\mathrm{CH}-\mathrm{CH}-$ $\left(\delta_{\mathrm{H}} 2.08,1.70,0.72,0.70,0.51\right.$ and 2.69$)$. The presence of a gem-dimethyl-substituted cyclopropane ring was indicated by signals of a quaternary carbon $\left(\delta_{\mathrm{C}} 18.3\right)$ and the signals at $\delta_{\mathrm{H}} 0.70 \mathrm{~m}, 0.51 \mathrm{t}$, $1.05 \mathrm{~s}, 0.96 \mathrm{~s}$ and $\delta_{\mathrm{C}} 25.5,19.0,28.5$ and 15.2. The connectivities of the 2 structural fragments, including the gem-dimethyl-substituted cyclopropane ring, were determined from the $\mathrm{C}-\mathrm{H}$ correlations in the HMBC spectrum. The long-range $\mathrm{C}-\mathrm{H}$ correlations of the quaternary carbons $\left(\delta_{\mathrm{C}}\right.$ $52.3,18.3,85.9$ and 80.3$)$ with protons of the 2 structural fragments established a pentacyclic premyrsinane diterpene with $O$-functionalities on C-3, C-5, C-14 and C-15. A saturated furan ring through $\mathrm{C}-17$ and $\mathrm{C}-13$ was determined by analysis of the $\mathrm{HMBC}$ spectrum. This kind of furan ring is typical for many myrsinane, cyclomyrsinane and premyrsinane esters. Moreover, the positions of the ester groups were determined from HMBC experiment. The long-range correlations indicated the presence of an $n$-hexanoyl group on C-3 and an acetyl group on C-14. Two proton signals, at $\delta_{\mathrm{H}}$ 3.75 and 1.58, which exhibited no correlations to any carbon in the HSQC spectrum, were assigned to 2 hydroxy groups (on C-5 and C-15). The relative configuration of EFAL-3 was investigated in a NOESY experiment. It was deduced by starting from the $\alpha$-position of the proton at the ring junction $(\mathrm{H}-4)$, characteristic of many types of Euphorbiaceae diterpenes. The NOEs between $\mathrm{H}-11 / \mathrm{H}-9, \mathrm{H}-$ $11 / \mathrm{H}-17 \mathrm{~b}$ and $\mathrm{H}-2 / \mathrm{H}-1 \alpha$ proved the $\alpha$-orientation of all these protons. The NOE interactions between $\mathrm{H}-5 / \mathrm{H}-86, \mathrm{H}-5 / \mathrm{H}-12, \mathrm{H}-5 / \mathrm{OH}-15$ and $\mathrm{H}-12 / 10-\mathrm{CH}_{3}$ (C-19) indicated the 8 -orientation of these protons.

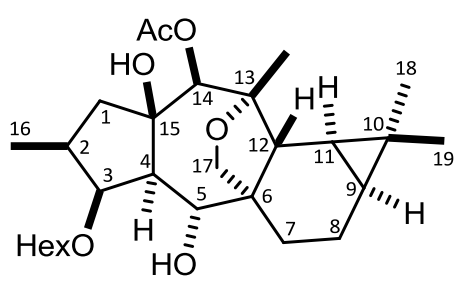

12

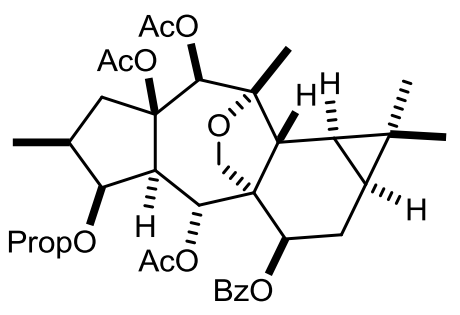

13

EFAL-4

EFAL-4 (13), with molecular formula $\mathrm{C}_{36} \mathrm{H}_{46} \mathrm{O}_{11}$, was isolated as a colourless amorphous solid. On the basis of NMR analyses, 3 acetyl $\left[\delta_{\mathrm{H}} 2.16,2.07\right.$ and 1.43; $\delta_{\mathrm{C}} 170.5,169.3$ and 168.5 (CO) and 22.7, 21.2 and $\left.21.1\left(\mathrm{CH}_{3}\right)\right]$, 1 benzoyl $\left(\delta_{\mathrm{H}} 7.98,7.41\right.$ and 7.54; $\delta_{\mathrm{C}} 166.3,133.0,130.4,130.0$ and 128.3$)$ and 1 propanoyl group $\left(\delta_{\mathrm{H}} 2.25,2.21\right.$ and 1.03; $\left.\delta_{\mathrm{C}} 174.1,27.7,9.0\right)$ were identified. Furthermore, the resonances of 4 methyls, 3 methylenes, 9 methines and 4 quaternary carbons were shown in the 
JMOD spectra. The ${ }^{1} \mathrm{H}-{ }^{1} \mathrm{H}$ COSY of EFAL-4 revealed the structural elements $-\mathrm{CH}_{2}-\mathrm{CH}\left(\mathrm{CH}_{3}\right)-\mathrm{CHR}-\mathrm{CH}-$ CHR- (C-1-C-2(C-16)-C-3-C-4-C-5) and - $\mathrm{CHR}-\mathrm{CH}_{2}-\mathrm{CH}-\mathrm{CH}-\mathrm{CH}-(\mathrm{C}-7-\mathrm{C}-12)$. The connection of these partial structures was shown by the HMBC spectra. It emerged that EFAL-4 is also a premyrsinane derivate. The ${ }^{1} \mathrm{H}$ and ${ }^{13} \mathrm{C}$ chemical shifts and coupling constants of EFAL-3 and EFAL-4 were very similar, except for the signals of $\mathrm{C}-7$ and $\mathrm{H}-7$. For EFAL-4, the $\delta_{\mathrm{H}-7} 4.85$ and $\delta_{\mathrm{C}-7} 73.7$ signals clearly demonstrated $\mathrm{O}$-substitution on $\mathrm{C}-7$. The locations of the ester groups were identified through an HMBC experiment. A careful comparison of the NOESY spectra of EFAL-3 and EFAL-4 suggested the same stereochemistry for these compounds. The 8 -orientation of the 7-benzoyl group in EFAL-4 was determined from the NOESY cross-peak between $\mathrm{H}-7$ and $\mathrm{H}-8 \alpha, \mathrm{H}-9, \mathrm{H}-17 \mathrm{~b}$.

EFAL-6

EFAL-6 (14) was obtained as a colourless amorphous solid with the molecular formula $\mathrm{C}_{35} \mathrm{H}_{46} \mathrm{O}_{10}$. From the ${ }^{1} \mathrm{H}$ NMR and JMOD spectra, 4 ester residues were identified as 2 acetyl, 1 isobutanoyl and 1 benzoyl groups. Additionally, these spectra and the ${ }^{1} \mathrm{H}-{ }^{1} \mathrm{H}$ COSY, HSQC and HMBC exhibited resonances closely related to those of EFAL-4, and it was obvious that compounds EFAL-4 and EFAL6 differ only in the substitution on $\mathrm{C}-3$ and $\mathrm{C}-5$, i.e. the propanoyl residue should be replaced by an isobutanoyl group and an acetyl group by a hydroxy group. A careful comparison of the NOESY spectra of EFAL-4 and EFAL- 6 led to the same relative configuration being inferred for these compounds.

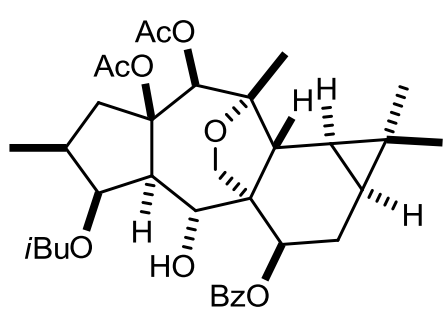

14

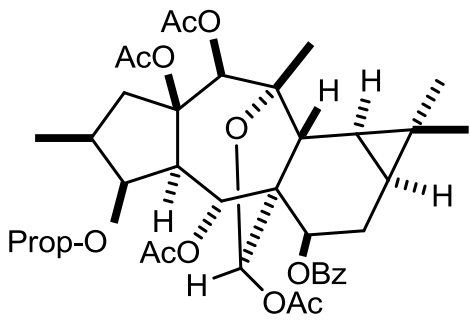

15

EFAL-7

EFAL-7 (15) was isolated as a colourless amorphous solid. The HRESIMS and NMR analyses indicated the molecular formula $\mathrm{C}_{38} \mathrm{H}_{48} \mathrm{O}_{13}$. The ${ }^{1} \mathrm{H}$ NMR and JMOD spectra of this compound revealed the presence of 4 acetyl $\left[\delta_{H} 2.21,2.11,2.05\right.$ and 1.27; $\delta_{C} 170.0,169.9,169.4$ and 168.3 (CO) and 22.9, $2 \mathrm{x}$ 21.2 and $\left.20.9\left(\mathrm{CH}_{3}\right)\right], 1$ benzoyl $\left(\delta_{\mathrm{H}} 7.95,7.53\right.$ and $7.41 ; \delta_{\mathrm{C}} 166.2,133.2,132.9,130.4$ and 128.4$)$ and 1 propanoyl group $\left(\delta_{\mathrm{H}} 2.33,2.25\right.$ and $\left.1.09 ; \delta_{\mathrm{C}} 174.0,23.6,8.9\right)$. Analysis of the ${ }^{1} \mathrm{H}-{ }^{1} \mathrm{H}$ COSY, HSQC and HMBC spectra of EFAL-7 showed that this compound has a similar parent system to that of EFAL-3, EFAL-4 and EFAL-6. The spectroscopic data were especially similar to those of EFAL-6, the main difference between these compounds being the presence of a further $O$-functionality in EFAL-7. A careful comparison of the NOESY spectra of EFAL-7 and the other compounds indicated 
the same stereochemistry. As concerns the chiral centre C-17, the strong NOESY cross-peak between $\mathrm{H}-4 / \mathrm{H}-17$ proved the configuration of $\mathrm{C}-17$ as depicted in structural formula 15.

\section{EFAL-19}

EFAL-19 (16), with molecular formula $\mathrm{C}_{44} \mathrm{H}_{56} \mathrm{O}_{16}$, was isolated as an amorphous solid. The ${ }^{1} \mathrm{H}$ NMR and JMOD spectra exhibited typical signals for 4 acetyl $\left[\delta_{\mathrm{H}} 1.97,2.09,2.12\right.$ and $2.16 ; \delta_{\mathrm{C}} 169.7,168.8$, 170.2 and $168.0(\mathrm{CO})$ and 20.8, 21.6, 21.3 and $23.1\left(\mathrm{CH}_{3}\right)$ ], 1 benzoyl $\left(\delta_{\mathrm{H}} 7.89,7.53\right.$ and 7.40; $\delta_{\mathrm{C}}$ $164.7,133.0,130.3,129.6$ and 128.3$), 1$ isobutanoyl $\left(\delta_{H} 2.39,1.05\right.$ and $0.99 ; \delta_{C} 175.4,34.1,18.9$ and 18.4), and 12 -methylbutanoyl groups $\left(\delta_{\mathrm{H}} 2.60,1.70,1.55\right.$ and $0.87 ; \delta_{\mathrm{C}} 174.7,40.9,27.0$ and 11.0). Furthermore, the resonances of 3 methyls were identified in the ${ }^{1} \mathrm{H}$ NMR spectrum. Informative signals at $\delta_{\mathrm{H}} 4.28$ and 3.63 indicated the presence of a tetrahydrofuran ring of a myrsinane-type skeleton. The JMOD and HSQC spectra (Figure 6) suggested that the skeleton consists of 20 carbons: 3 methyls, 3 methylenes, 8 methines and 6 quaternary carbons.

The structural elements determined via the ${ }^{1} \mathrm{H}-{ }^{1} \mathrm{H}$ COSY spectrum (Figure 7) were connected by inspection of the long-range $\mathrm{C}-\mathrm{H}$ correlations observed in the $\mathrm{HMBC}$ spectrum (Figure 8). The 2- and 3-bond correlations between the quaternary carbon $\mathrm{C}-2$ and $\mathrm{H}-1$ and $\mathrm{H}-16$, between the quaternary $\mathrm{C}-15$ and $\mathrm{H}-1$ and $\mathrm{H}-3$, and between the $\mathrm{C}-4$ and $\mathrm{H}-1$ and $\mathrm{H}-5$ signals revealed that structural fragment $A$, together with quaternary $C-2$ and $C-15$, forms a 5 -membered ring.

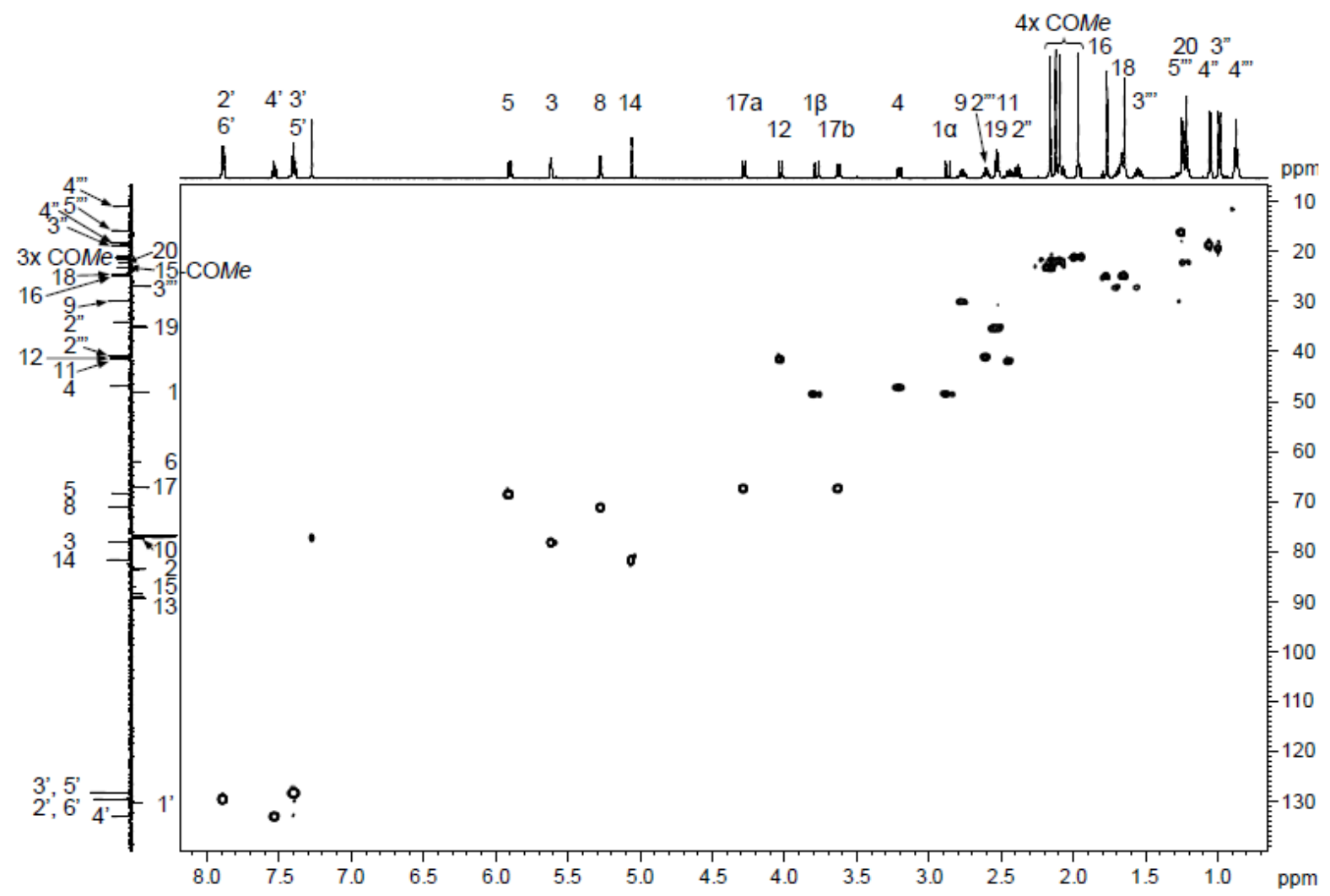

Figure 6. HSQC spectrum of 16. 


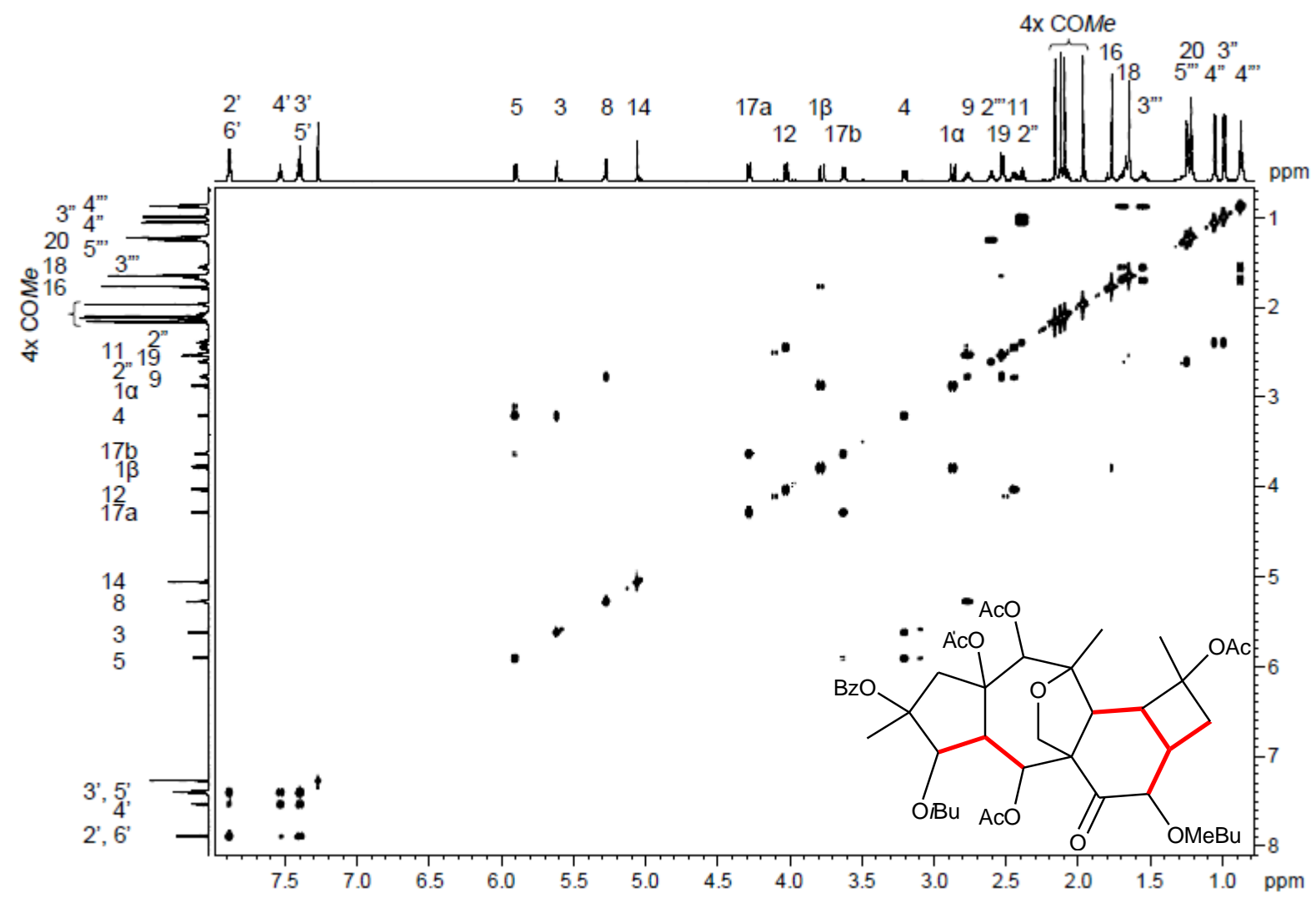

Figure 7. ${ }^{1} \mathrm{H}-{ }^{1} \mathrm{H}$ COSY spectrum and correlations (-) of 16.

HMBC cross-peaks between $\mathrm{C}-6$ and $\mathrm{H}-5, \mathrm{H}-8$ and $\mathrm{H}-12$, between $\mathrm{C}-7$ and $\mathrm{H}-8$ and between $\mathrm{C}-10$ and $\mathrm{H}-11, \mathrm{H}-12$ and $\mathrm{H}-19$ established a cyclomyrsinane diterpene with $\mathrm{O}$-functionalities on C-2, C-3, C-5, C-7, C-8, C-10, C-14 and C-15. Additionally, the heteronuclear long-range coupling between $\mathrm{H}-17 \mathrm{a}$ and $\mathrm{C}-13$, and between $\mathrm{C}-5$ and $\mathrm{H}-12$ and $\mathrm{H}-17$, indicated an $\mathrm{O}$-bridge between $\mathrm{C}-17$ and $\mathrm{C}-13$. The positions of the ester groups were also determined via the HMBC experiment. These $\mathrm{C}-\mathrm{H}$ correlations exhibited the presence of acetyl groups on C-5, C-10, C-14 and C-15, an isobutanoyl group on C-3, and a 2-methylbutanoyl group on C-8. The positions of 2-OBz, 10-OAC and 15-OAC groups were also suggested by the NOESY correlations. 


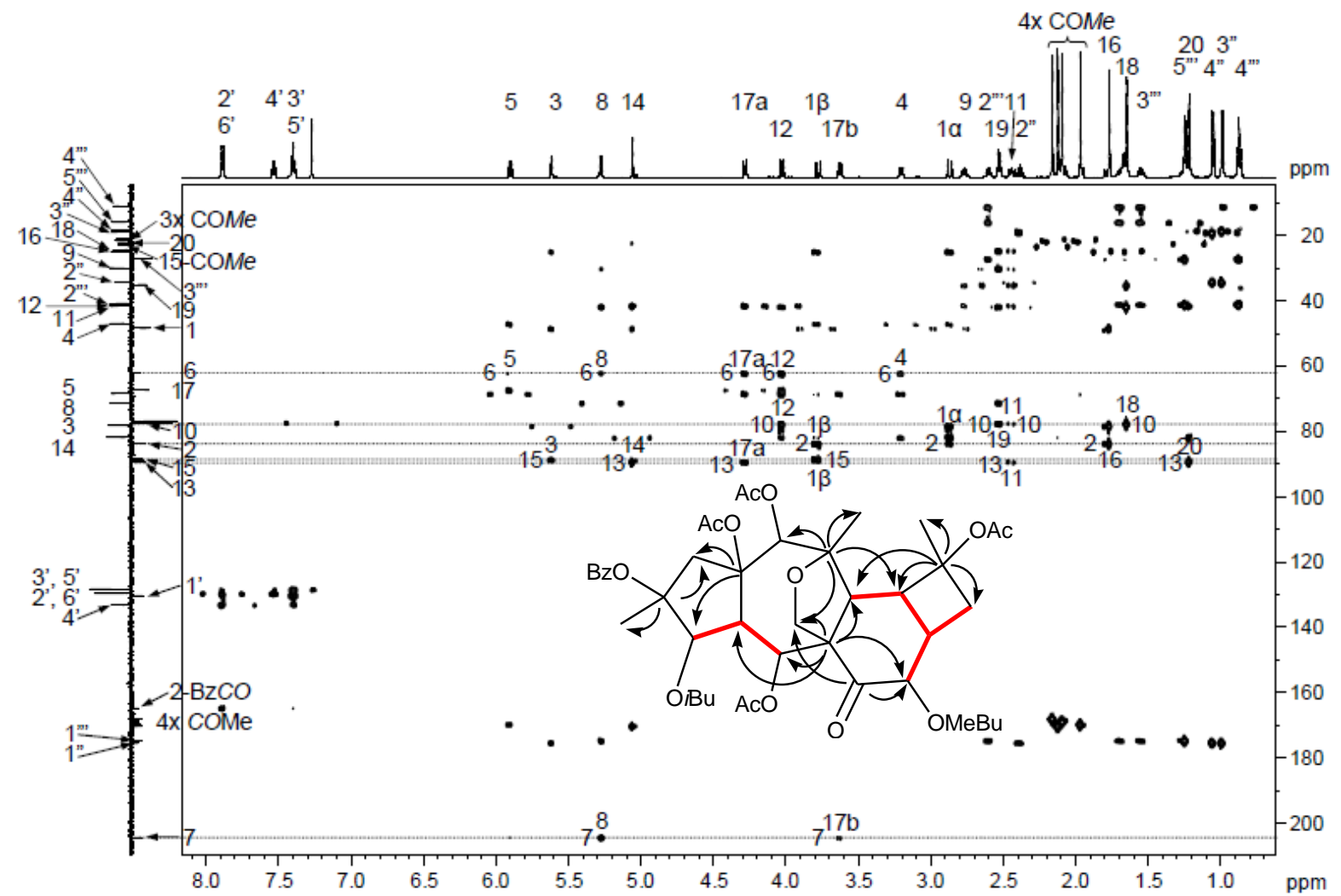

Figure 8. $\mathrm{HMBC}$ spectrum and ${ }^{1} \mathrm{H}-{ }^{1} \mathrm{H} \operatorname{COSY}(-)$ and $\mathrm{HMBC}(\mathrm{C} \rightarrow \mathrm{H})$ correlations of 16.

The stereochemistry and relative configuration of EFAL-19 were studied by means of a NOESY experiment (Figure 9). The relative configuration of EFAL-19 was deduced by starting from the $\alpha$ orientation of $\mathrm{H}-4$. Cross-peaks between $\mathrm{H}-4 / \mathrm{H}-3, \mathrm{H}-4 / \mathrm{H}-14, \mathrm{H}-4 / \mathrm{H}-16, \mathrm{H}-3 / 5-\mathrm{OAc} \mathrm{H}-14 / \mathrm{H}-1 \alpha$ and $\mathrm{H}-$ $16 / \mathrm{H}-1 \alpha$ proved the 8 -orientation of the 3-O-isobutanoyl, $\mathrm{H}-5,14-\mathrm{O}$-acetyl and 2-O-benzoyl groups. The NOEs between $\mathrm{H}-5 / \mathrm{H}-12$ and $\mathrm{H}-12 / \mathrm{H}-20$ showed the 8 -orientation of these protons. Additionally, the NOEs between 5-OAc/H-8, H-8/H-9, H-9/H-18 and $\mathrm{H}-18 / \mathrm{H}-11$ confirmed the $\alpha-$ orientation of all these protons. NOESY cross-peaks between $\mathrm{H}-4 / \mathrm{H}-17 \mathrm{a}$ and $\mathrm{H}-11 / \mathrm{H}-17 \mathrm{~b}$ proved that the $-\mathrm{CH}_{2}-\mathrm{O}-$ bridge is oriented below the plane of the carbon skeleton.

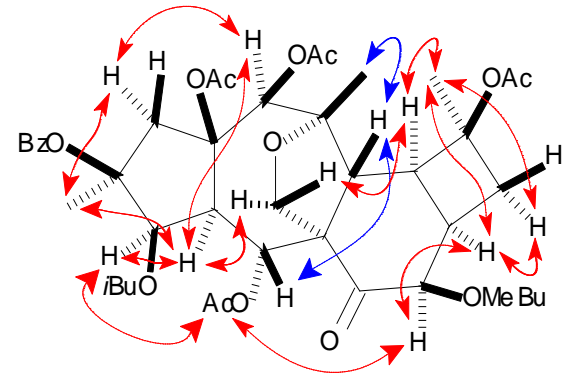

Figure 9. Diagnostic NOESY correlations for compound 16. 
EFAL-20

EFAL-20 (17) was obtained as white crystals. It was found to be identical in all of its characteristics, including the ${ }^{1} \mathrm{H}$ NMR spectral data, with SPr4 isolated earlier from Euphorbia prolifera. ${ }^{181}$

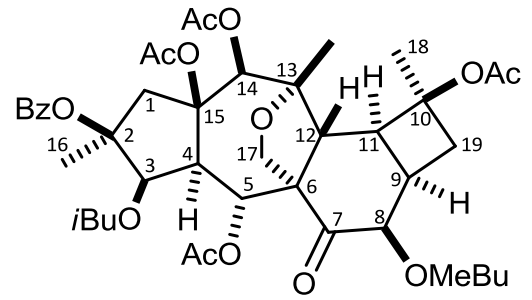

16

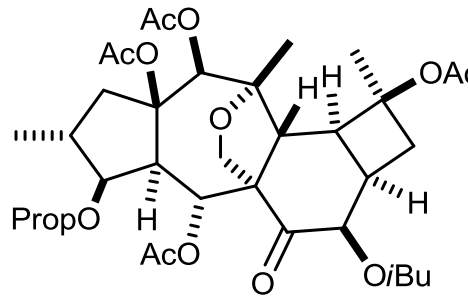

17

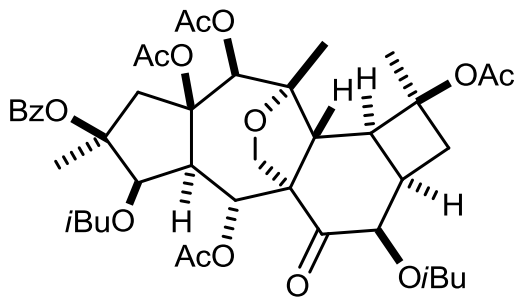

18

EFAL-21

EFAL-21 (18), with molecular formula $\mathrm{C}_{43} \mathrm{H}_{54} \mathrm{O}_{16}$, was isolated as white crystals. The ${ }^{1} \mathrm{H}$ NMR and JMOD spectra of EFAL-21 revealed 4 acetyl $\left[\delta_{\mathrm{H}} 1.96,2.09,2.12\right.$ and $2.15 ; \delta_{\mathrm{C}} 169.8,168.8,170.2$ and $168.1(\mathrm{CO})$ and 20.8, 21.6, 21.3 and $\left.23.0\left(\mathrm{CH}_{3}\right)\right], 1$ benzoyl $\left(\delta_{\mathrm{H}} 7.88,7.52\right.$ and 7.39; $\delta_{\mathrm{C}}$ 164.7, 133.0, $130.3,129.6$ and 128.3$)$, and 2 isobutanoyl groups $\left(\delta_{\mathrm{H}} 2.37,1.05\right.$ and 0.98 , and 2.75, 1.25 and 1.22; $\delta_{\mathrm{C}} 175.4,34.1,18.9$ and 18.3 , and 175.1, 34.4, 20.3 and 18.5). After the ${ }^{1} \mathrm{H}$ and ${ }^{13} \mathrm{C}$ NMR data on EFAL-21 had been assigned by analysis of its ${ }^{1} \mathrm{H}-{ }^{1} \mathrm{H}$ COSY, HSQC and HMBC spectra, it was obvious that EFAL-21 and EFAL-19 are based on the same parent system and differ only in the substitution on C-8 (replacement of a 2-methylbutanoyl residue with an isobutanoyl group). A careful comparison of the NOESY spectra of EFAL-19 and EFAL-21 led to the conclusion that the stereochemistry of these compounds is the same. 


\section{DISCUSSION}

Phytochemical investigations of E. pannonica, E. esula, and E. falcata led to the isolation of 18 diterpenes, including 14 new natural products. The structures were established by means of spectral analyses as esters of jatrophane, tigliane, premyrsinane and cyclomyrsinane-type diterpenes. Biological investigations revealed that some of the isolated compounds possess noteworthy pharmacological activities (antiproliferative and MDR-reversing).

\subsection{Isolation of diterpenes}

- Screening of E. pannonica and E. falcata led to the conclusion that the lipophilic extracts contain a number of diterpene esters, which can be enriched by polyamide OCC, mainly in the $60 \%$ aqueous $\mathrm{MeOH}$ fraction. The purification of the compounds generally requires the involvement of multistep separation methods because the plants produce complex mixtures of esters of the same diterpene nucleus (these may display very similar chromatographic characters), and the compounds occur merely in low quantities in the plants. The diterpene content of E. esula was known from previous literature data; screening for diterpene content was not needed.

- The fresh (frozen) whole plant materials were extracted with $\mathrm{MeOH}$ at room temperature by percolation. $\mathrm{MeOH}$, an amphipolar solvent, was suitable for the extraction of both lipophilic and polar compounds.

- In the initial step of separation, liquid-liquid extraction with $\mathrm{CHCl}_{3}$ was applied in order to remove the polar constituents. The purification was continued with classical OCC. In accordance with the screening investigations, polyamide proved to be suitable as stationary phase for the preparative work, with the use of $\mathrm{MeOH}-\mathrm{H}_{2} \mathrm{O}$ solvent systems. The $20-60 \% \mathrm{MeOH}$ fractions were rich in diterpenes, the $80 \% \mathrm{MeOH}$ fractions contained mainly triterpenes and chlorophyll.

- In the following steps, even more selective methods (VLC, RPC, PLC and HPLC) were applied. After polyamide OCC, adsorption chromatography on silica gel was used in all experiments. VLC and RPC separations of the diterpene fractions afforded crude fractionations of the main components. For final purification, NP- and RP-HPLC were applied since these were the most effective and most selective separation methods. HPLC provided mild conditions for polyester-type (light- and heatsensitive) diterpenes.

- The preparative work was completed with analytical TLC on silica gel with various solvent systems. The aims of the TLC analysis were to model the separation methods, to combine fractions, and to check the purity of the isolated compounds. The detection was carried out in UV light at 254 $\mathrm{nm}$, followed by spraying with cc. $\mathrm{H}_{2} \mathrm{SO}_{4}$. 
- As a result of the isolation procedure, 18 compounds, occurring in low concentration, were obtained from the multicomponent samples. Usually, compounds with very similar structures were separated per plant, most of the isolated components differing from each other only in the ester groups, and EPAN-3 (1) and EPAN-7 (2), EUP-23 (7) and EUP-26 (9), and EFAL-19 (16) and EFAL-20 (17) differing in only 1 substituent. After extensive chromatographic purification, 2 compounds were isolated from E. pannonica (EPAN-3 and EPAN-7), 9 from E. esula (EUP-13, EUP-17, EUP-18, EUP-20, EUP-23, EUP-26, EUP-28, EUP-29 and EUP-32), and 7 from E. falcata (EFAL-3, EFAL-4, EFAL-6, EFAL-7, EFAL-19, EFAL-20 and EFAL-21).

\subsection{Structure elucidation}

- The isolated compounds are amorphous solids or crystals. They are optically active. The structures of the isolated compounds were elucidated by means of spectroscopic methods. From HRESIMS measurements, the molecular compositions were determined. The most useful data concerning the chemical structures were furnished by $1 \mathrm{D}$ and $2 \mathrm{D}$ NMR spectroscopy. From the ${ }^{1} \mathrm{H}$ and ${ }^{13} \mathrm{C}$ NMR, ${ }^{1} \mathrm{H}-{ }^{1} \mathrm{H}$ COSY, HSQC and $\mathrm{HMBC}$ experiments, the constitutions of the compounds were determined, and then, with the aid of the NOESY spectra, the relative configurations were elucidated. In the isolated compounds, the number of asymmetric carbons was $8-13$, and all of them were characterized stereochemically. As a result of the NMR studies $\left({ }^{1} \mathrm{H} N M R, J M O D,{ }^{1} \mathrm{H}-{ }^{1} \mathrm{H}\right.$ COSY, HSQC and $\mathrm{HMBC}$ ), complete ${ }^{1} \mathrm{H}$ and ${ }^{13} \mathrm{C}$ assignments were made for the characterization of the compounds.

- Structurally, 9 of the compounds are jatrophanes or modified jatrophanes, 2 are tiglianes, 4 are premyrsinanes and 3 are cyclomyrsinane-type compounds. EPAN-3 (1) and EPAN-7 (2) are derivatives of 4,12-dideoxyphorbol, a diterpene alcohol that is very rare in the plant kingdom. Furthermore, EPAN-7 (2) is substituted with an isovalerianate group, which was found for the first time in the group of tigliane diterpenes.

- EUP-18 (6), EUP-23 (7), EUP-29 (8), EUP-26 (9) and EUP-17 (11) isolated from E. esula contain a nicotinoyl group, and can therefore be regarded as pseudoalkaloids. The diversity of the ester groups is characteristic for the members of EFAL series, e.g. in EFAL-19 (16) 4 (acetyl, isobutanoyl, 2methylbutanoyl and benzoyl), and in EFAL-4 (13), EFAL-6 (14), EFAL-7 (15), EFAL-20 (17) and EFAL-21 (18) 3 different ester groups were found. EUP-20 (3) is the most highly esterified jatrophane diterpenoid, with 8 ester groups. Besides ester groups, hydroxy and keto functions are also present in the molecules. In EUP-20 (3), an ether function is to be found between C-11 and C-14, and it therefore possesses an unusual heterocyclic ring system. Such compounds have been isolated earlier only from E. kansui and E. esula. ${ }^{173,182,183}$ The EUP series is stereochemically homogeneous, characterized by 26 -methyl, $13 \alpha$-methyl and $36,76,5 \alpha, 8 \alpha, 9 \alpha$ and 156 -acyl substitution. 
- In the EFAL series, EFAL-7 (15) contains a rare hemiacetal moiety, such diterpenes being very rare in the Euphorbiaceae. EFAL-3 (12), EFAL-4 (13), EFAL-6 (14) and EFAL-7 (15) are the first known premyrsinane-type diterpenes containing an acyl moiety instead of a keto group on C-14. Biogenetically, premyrsinanes can be derived from epoxylathyranes by intramolecular cyclization, and they are the precursors of cyclomyrsinanes. Cyclomyrsinane diterpenes are very rare in the plant kingdom; only 7 compounds have been isolated previously from other Euphorbia species. Moreover, EFAL-19 (16) and EFAL-20 (17) are substituted with an ester group at C-2, which is also unprecedented. Similarly to the EUP series, the EFAL series is stereochemically homogeneous, but interestingly the configuration of C-16 is 6 in the premyrsinanes (EFAL-3, EFAL-4, EFAL- 6 and EFAL-7) and $\alpha$ in the cyclomyrsinanes (EFAL-19 - EFAL-21).

\subsection{Chemotaxonomical significance}

- Diterpenes are considered to be important taxonomic markers of the Euphorbiaceae family, because of its limited occurrence and structural diversity.

- On the basis of the diterpene composition, E. esula displays a close relationship with $E$. salicifolia; these species belong in the same section. They contain the same main diterpene components, esulatin A, EUP-13 (salicinolide, 10) and EUP-17 (euphosalicine, 11) and other jatrophane diterpenes differing only in the esterification.

- The diterpenes isolated from E. esula in our experiment are not identical with those obtained by other workgroups. ${ }^{16,104,105,147-150,153}$ The samples of different origins (China, North America and Hungary) contain different diterpenes. In the EUP series obtained from the Hungarian collection, the alcohol core of the compounds was different. In this species, the morphological diversity (characteristic of E. esula) is manifested in the chemical features (the diterpene profile), too.

- The chemical constituents of E. pannonica and E. falcata have not been investigated previously.

- All of the isolated diterpenes were detected for the first time in the given plants.

\subsection{Biological activities}

The isolated compounds were tested for their antitumour and MDR-reversing activities.

- Antitumour activity: As many experimental data have been published in the past few years on the antitumour activities of Euphorbiaceae diterpenes, ${ }^{157-168}$ the antiproliferative activities of the isolated diterpenes, together with 5 jatrophane diterpenes (esulatins A, B, D-F; Figure 10) identified in our earlier experiments were evaluated against human tumour cell lines [HeLa (cervical adenocarcinoma), Ishikawa (endometrial adenocarcinoma), MCF7 (breast epithelial adenocarcinoma) and A431 (skin carcinoma)] using the MTT test and with cisplatin as positive control. 


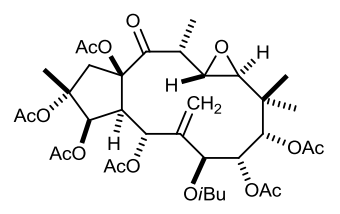

esulatin A

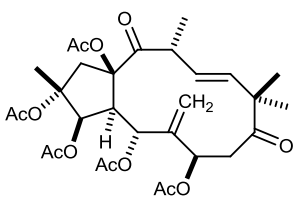

esulatin B

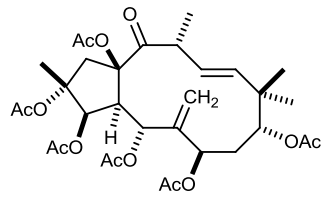

esulatin $D$

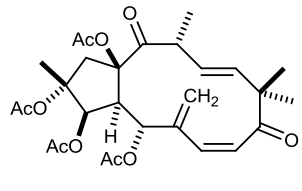

esulatin $\mathrm{E}$

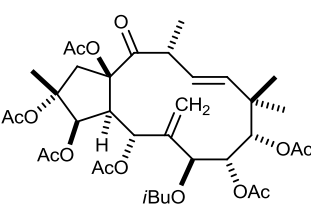

esulatin $\mathrm{F}$

Figure 10. Diterpenes isolated previously from E. esula

The results presented in Table 3 revealed that the isolated diterpenes possess different cell growth-inhibitory activities; substantial effects were recorded only at the higher tested concentration: $30 \mu \mathrm{g} / \mathrm{mL}$. EUP-32 (esulatin J, 5), and esulatins $A$ and $E$ were the most effective against all cell lines; especially EUP-32 (5) exhibited high cell growth-inhibitory activity on Ishikawa $(98.4 \%$, at $30 \mu \mathrm{g} / \mathrm{mL})$ and MCF7 (81.4\%, at $30 \mu \mathrm{g} / \mathrm{mL})$ cells.

Table 3. Inhibition (\%) of tumour cell proliferation by Euphorbia diterpenes. ${ }^{a}$

\begin{tabular}{|c|c|c|c|c|c|c|c|c|}
\hline \multirow[t]{2}{*}{ Compound } & \multicolumn{2}{|c|}{ HeLa } & \multicolumn{2}{|c|}{ Ishikawa } & \multicolumn{2}{|c|}{ MCF7 } & \multicolumn{2}{|c|}{ A431 } \\
\hline & $\begin{array}{c}10 \\
\mu \mathrm{g} / \mathrm{mL}\end{array}$ & $\begin{array}{c}30 \\
\mu \mathrm{g} / \mathrm{mL}\end{array}$ & $\begin{array}{c}10 \\
\mu \mathrm{g} / \mathrm{mL}\end{array}$ & $\begin{array}{c}30 \\
\mu \mathrm{g} / \mathrm{mL}\end{array}$ & $\begin{array}{c}10 \\
\mu \mathrm{g} / \mathrm{mL}\end{array}$ & $\begin{array}{c}30 \\
\mu \mathrm{g} / \mathrm{mL}\end{array}$ & $\begin{array}{c}10 \\
\mu \mathrm{g} / \mathrm{mL}\end{array}$ & $\begin{array}{c}30 \\
\mu \mathrm{g} / \mathrm{mL}\end{array}$ \\
\hline EUP-20 (3) & 10.6 & 17.8 & 12.0 & 17.7 & 9.8 & 11.4 & - & - \\
\hline EUP-28 (4) & 15.4 & 23.8 & 8.0 & 29.4 & 12,7 & 60.1 & - & - \\
\hline EUP-32 (5) & 19.1 & 64.5 & 18.4 & 98.4 & 46.8 & 81.4 & - & - \\
\hline EUP-18 (6) & 17.3 & 36.3 & 11.6 & 35.0 & 29.9 & 43.3 & - & - \\
\hline EUP-23 (7) & 0.5 & 0.6 & 7.5 & 0.1 & 1.3 & 21.3 & - & - \\
\hline EUP-29 (8) & 6.4 & 1.1 & 17.5 & 26.6 & 3.6 & 16.7 & - & - \\
\hline EUP-26 (9) & 18.3 & 4.5 & 5.9 & 16.4 & 18.5 & 14.4 & - & - \\
\hline EUP-13 (10) & 13.9 & 17.9 & 8.1 & 13.9 & 20.3 & 36.3 & - & - \\
\hline EUP-17 (11) & 11.4 & 26.7 & 29.4 & 29.9 & 9.5 & 13.5 & - & - \\
\hline esulatin A & 16.3 & 62.6 & 20.1 & 53.8 & 21.4 & 47.9 & - & - \\
\hline esulatin B & 2.9 & 10.9 & 21.4 & 17.1 & 8.7 & 23.3 & - & - \\
\hline esulatin D & 5.3 & 20.8 & 31.5 & 33.0 & 24.8 & 29.2 & - & - \\
\hline esulatin $\mathrm{E}$ & 19.5 & 58.1 & 35.6 & 54.1 & 30.4 & 61.4 & - & - \\
\hline esulatin F & 14.5 & 18.1 & 0.9 & 7.6 & 6.3 & 20.0 & - & - \\
\hline EFAL-3 (12) & 12.8 & 60.4 & - & - & 30.6 & 56.0 & 23.0 & 35.6 \\
\hline EFAL-4 (13) & 22.2 & 56.9 & - & - & 21.1 & 49.1 & 36.2 & 81.4 \\
\hline EFAL-6 (14) & 25.8 & 83.9 & - & - & 33.6 & 59.2 & 38.0 & 93.6 \\
\hline EFAL-7 (15) & 20.6 & 47.3 & - & - & 25.9 & 38.9 & 39.2 & 69.1 \\
\hline EFAL-19 (16) & 21.9 & 33.3 & - & - & 29.8 & 43.0 & 32.4 & 40.3 \\
\hline EFAL-20 (17) & 16.9 & 33.7 & - & - & 17.3 & 53.3 & 38.9 & 45.1 \\
\hline EFAL-21 (18) & 18.1 & 14.1 & - & - & 4.9 & 17.0 & 23.4 & 17.9 \\
\hline
\end{tabular}

${ }^{a}$ Positive control cisplatin: $12.4 \mu \mathrm{M}$ (HeLa), $3.5 \mu \mathrm{M}$ (Ishikawa and A431) and 9.6 $\mu \mathrm{M}$ (MCF-7).

In the case of the diterpenes isolated from E. falcata (12-18), weak or moderate cell growthinhibitory activities were detected; substantial effects were recorded only at the higher tested concentration $(30 \mu \mathrm{g} / \mathrm{mL})$ for compound 14 , which showed significant activity in all 3 cell lines [83.9\% (HeLa), 93.6\% (A431) and 59.2\% (MCF7) at $30 \mu \mathrm{g} / \mathrm{mL}$ ). Compound 13 exerted inhibitory activity on HeLa $(56.95 \%$ at $30 \mu \mathrm{g} / \mathrm{mL})$ and A431 $(81.4 \%$ at $30 \mu \mathrm{g} / \mathrm{mL})$ cells, while EFAL-3 (12) 
exhibited $60.4 \%$ inhibitory activity on HeLa and $56.0 \%$ on MCF-7 cell lines at $30 \mu \mathrm{g} / \mathrm{mL}$. Moreover, EFAL-7 (15) displayed antiproliferative activity only against A431 $(69.1 \%$ at $30 \mu \mathrm{g} / \mathrm{mL})$ cells, and EFAL-20 (17) had a weak effect on MCF7 (53.3\% at $30 \mu \mathrm{g} / \mathrm{mL})$.

The structure-activity relationships are not easy to evaluate, because the structural variations within the set of compounds isolated from E. esula are very complex, stemming from the variations in the substitution on C-2, C-7 and C-9, from the nature of the ester groups on C-2, C-3, C-5, C-7, C-8 and C-9, from the number and positions of the double bonds, and from the presence or absence of a keto or epoxy functionality. The most potent compounds found, esulatins I (EUP-28, 4), J (EUP-32, 5) and $E$, are tetra- or pentaesters of jatrophane polyols, which contain a keto group on C-9. Moreover, esulatin $A$, containing an epoxy group on $\mathrm{C}-11-\mathrm{C}-12$, also proved effective against all 3 cell lines. Of the components of E. falcata, the premyrsinanes (12-15) showed higher cell growth-inhibitory activities than those of the cyclomyrsinanes. Among them, EFAL-7 (15) is the only one substituted with a hemiacetal moiety and exhibiting high antiproliferative activity on A431 cells.

- MDR-reversal activity: The discovery of jatrophane diterpenes as a new class of potent inhibitors of P-gp has led to increasing interest in research on this type of compounds. Many powerful inhibitors have been identified among jatrophane and modified jatrophane diterpenes, which are promising compounds for drug development because of their manifold higher potencies than those of the positive controls, cyclosporin A or verapamil.

The investigation of the compounds for their capacity to inhibit rhodamine 123 (a fluorescent dye) efflux by MDR mouse lymphoma cells showed that the isolated diterpenes differ significantly in their inhibition of the efflux pump activity of P-gp in tumour cells (Table 4). Within the set of EUP compounds investigated, esulatin J (EUP-32, 5) [fluorescence activity ratio $(R)=52.5$ at $40 \mu \mathrm{g} / \mathrm{mL}$ ] and esulatin M (EUP-29, 8) $(R=119.9$ at $40 \mu \mathrm{g} / \mathrm{mL})$, and in the EFAL series EFAL-4 (13) $(R=74.5$ at 20 $\mu \mathrm{g} / \mathrm{mL})$, EFAL-6 (14) $(R=69.3$ at $20 \mu \mathrm{g} / \mathrm{mL})$, EFAL-7 (15) $(R=52.9$ at $20 \mu \mathrm{g} / \mathrm{mL})$, EFAL-19 (16) $(R=52.7$ at $20 \mu \mathrm{g} / \mathrm{mL})$ and EFAL-20 (17) $(R=62.3$ at $20 \mu \mathrm{g} / \mathrm{mL})$ were found to be the most powerful inhibitors of efflux-pump activity. Their efficacy was 2-5-fold higher than that of the standard modulator verapamil, taken as a positive control $(R=23.2$ at $10 \mu \mathrm{g} / \mathrm{mL})$, and all of these compounds therefore appear to be promising leads for the development of drugs with which to overcome the MDR of cancer cells. 
Table 4. Reversal of the MDR of mouse lymphoma cells by diterpenoids isolated from E. esula and $E$. falcata, and the results of the combination assay in the case of E. falcata

\begin{tabular}{|c|c|c|c|c|c|c|}
\hline \multirow{2}{*}{ Compound } & \multirow{2}{*}{$\begin{array}{l}\text { Conc. } \\
\mu \mathrm{g} / \mathrm{mL}\end{array}$} & \multirow{2}{*}{$\begin{array}{l}\text { Fluorescence } \\
\text { activity ratio }{ }^{a}\end{array}$} & \multirow{2}{*}{ Compound } & \multirow{2}{*}{$\begin{array}{l}\text { Conc. } \\
\mu \mathrm{g} / \mathrm{mL}\end{array}$} & \multirow{2}{*}{$\begin{array}{l}\text { Fluorescence } \\
\text { activity ratio }^{a}\end{array}$} & \multirow{2}{*}{ FIX } \\
\hline & & & & & & \\
\hline \multirow{2}{*}{ EUP-20 (3) } & 4 & 1.4 & EFAL-3 (12) & 2 & 0.9 & 0.54 \\
\hline & 40 & 1.0 & & 20 & 1.4 & \\
\hline \multirow[t]{2}{*}{ EUP-28 (4) } & 4 & 3.9 & EFAL-4 (13) & 2 & 23.4 & 0.23 \\
\hline & 40 & 19.9 & & 20 & 74.4 & \\
\hline \multirow[t]{2}{*}{ EUP-32 (5) } & 4 & 24.9 & EFAL-6 (14) & 2 & 29.8 & 0.40 \\
\hline & 40 & 52.5 & & 20 & 69.3 & \\
\hline \multirow[t]{2}{*}{ EUP-18 (6) } & 4 & 7.2 & EFAL-7 (15) & 2 & 12.6 & 0.73 \\
\hline & 40 & 19.8 & & 20 & 52.9 & \\
\hline \multirow[t]{2}{*}{ EUP-23 (7) } & 4 & 23.8 & EFAL-19 (16) & 2 & 46.2 & 0.15 \\
\hline & 40 & 36.4 & & 20 & 52.7 & \\
\hline \multirow[t]{2}{*}{ EUP-29 (8) } & 4 & 16.6 & EFAL-20 (17) & 2 & 36.9 & 0.32 \\
\hline & 40 & 119.9 & & 20 & 62.3 & \\
\hline \multirow[t]{2}{*}{ EUP-26 (9) } & 4 & 1.7 & EFAL-21 (18) & 2 & 1.2 & 0.38 \\
\hline & 40 & 2.3 & & 20 & 5.2 & \\
\hline \multirow[t]{2}{*}{ EUP-13 (10) } & 2 & 5.9 & & & & \\
\hline & 40 & 17.5 & & & & \\
\hline \multirow{2}{*}{ EUP-17 (11) } & 4 & 1.9 & & & & \\
\hline & 40 & 12.3 & & & & \\
\hline \multirow[t]{2}{*}{ esulatin B } & 4 & 2.6 & & & & \\
\hline & 40 & 7.8 & & & & \\
\hline \multirow[t]{2}{*}{ esulatin D } & 4 & 4.6 & & & & \\
\hline & 40 & 15.2 & & & & \\
\hline \multirow[t]{2}{*}{ esulatin F } & 4 & 5.5 & & & & \\
\hline & 40 & 14.8 & & & & \\
\hline \multirow[t]{2}{*}{ esulatin A } & 4 & 2.0 & & & & \\
\hline & 40 & 1.9 & & & & \\
\hline verapamil & 10 & 23.2 & & 22 & 8.77 & \\
\hline
\end{tabular}

In the EFAL series, the high efficacy was supported by the data obtained in combination assays. All compounds were tested for their capacity to reduce the resistance of the MDR mouse lymphoma cell line to doxorubicin. The fractional inhibitory index (FIX) was obtained as the sum of the FIX values for each compound separately: FIX $=\mathrm{FIX}_{\text {compound }}+\mathrm{FIX}$ doxorubicin. The FIX value of each compound is the fractional $\mathrm{IC}_{50}$ of the combined drugs divided by their individual $\mathrm{IC}_{50}$ as follows: $\mathrm{FIX}_{\text {(compound) }}=$ $I C_{50 \text { (compound }+ \text { doxorubicin) }} / \mathrm{IC}_{50 \text { (compound) }}$ and $\mathrm{FIX}$ (doxorubicin) $=I \mathrm{I}_{50 \text { (compound }+ \text { doxorubicin) }} / \mathrm{IC}_{50 \text { doxorubicin }}$. As shown in Table 4, all the compounds exhibited a synergistic effect with doxorubicin, with combination index (FIX) values at $50 \%$ of growth of $0.54,0.23,0.40,0.73,0.15,0.32$ and 0.38 for compounds 12 to 18 , respectively. 
Among the members of the EUP series, EUP-32 (5) and EUP-29 (8) were the most active; both can be characterized by the absence of an ester group on C-2. Moreover, esulatin M (8) substituted with a nicotinoyl group on C-9 instead of a keto group (such as in 5) suggested that a 9-nicotinoyl group is also essential for high MDR-reversing activity. Among the premyrsinanes, EFAL-3 (12), which was inactive based on the FAR data and had low synergistic activity, differs structurally from the others because of the absence of the 7-OBz and 15-OAc groups, which therefore seem to be important for the activity of the compounds. The difference between $\mathbf{1 3}$ and $\mathbf{1 5}$ is an acetyl group on C-17, which seems to decrease the activity of the molecule. As regards the cyclomyrsinanes, EFAL-21 (18), without benzoyl substitution, possesses lower activity in the inhibition of the MDR1 pump (FAR results). The more active compounds $\mathbf{1 6}$ and $\mathbf{1 7}$ are also unsubstituted on C-17, similarly to $\mathbf{1 3}$, and differ from each other in the substitution on $\mathrm{C}-8$, which seems to influence the long-term response observed in the results of the combination with doxorubicin, but not the short-term experiment, as shown in the accumulation of the rhodamine 123 data (Table 4).

- From the above results, it could be concluded that the jatrophane, premyrsinane and cyclomyrsinane diterpenes could be therapeutically relevant natural products. 


\section{SUMMARY}

The aim of this work was the isolation, structure determination and pharmacological investigation of diterpenes from Euphorbia pannonica, E. esula and E. falcata. The isolation was carried out by a multistep separation procedure, including OCC, VLC, RPC, PLC and NP- and RP-HPLC. The structures of the isolated compounds were elucidated by means of spectroscopic methods (HR-MS and NMR). As a result of $1 \mathrm{D}\left({ }^{1} \mathrm{H},{ }^{13} \mathrm{C}\right.$ and JMOD) and 2D NMR studies (COSY, HSQC, HMBC and NOESY), complete ${ }^{1} \mathrm{H}$ and ${ }^{13} \mathrm{C}$ assignments were made for the characterization of the compounds.

As a result of our work, 2 new (1 and $\mathbf{2}$ ) diterpene polyesters were isolated from E. pannonica, 6 new ones (3-8) and 3 known ones (9-11) from $E$. esula, and 6 new ones (12-16 and 18) and 1 known one (17) from E. falcata. Nine compounds are polyesters of jatrophane and modified jatrophane, 2 of tigliane, 4 of premyrsinane and 3 of cyclomyrsinane-type. EUP-18 (6), EUP-23 (7), EUP-29 (8), EUP-26 (9) and EUP-17 (11) contain nicotinoyl group, and can therefore be regarded as pseudoalkaloids. The compounds are esterified with different acyl groups: acetyl, isobutanoyl, methylbutanoyl, propanoyl, hexanoyl, benzoyl or nicotionyl. EUP-20 (3) is the most highly esterified jatrophane-type diterpenoid, with 8 acyl groups. EFAL-19 (16) is the most diversely substituted diterpene, with 4 different ester groups (acetyl, isobutanoyl, 2-methylbutanoyl and benzoyl) in the molecule.

EPAN-3 (1) and EPAN-7 (2) are derivatives of 4,12-dideoxyphorbol, a diterpene alcohol that is very rare in the plant kingdom. Furthermore, EPAN-7 (2) is substituted with an isovaleroyl group, which was found for the first time in this group of tigliane diterpenes. In EUP-20 (3), an ether function is to be found between $\mathrm{C}-11$ and $\mathrm{C}-14$, and it therefore possesses an unusual heterocyclic ring system. EFAL-7 (15) contains a rare hemiacetal moiety, such diterpenes being very rare in Euphorbiaceae. EFAL-3 (12), EFAL-4 (13), EFAL-6 (14) and EFAL-7 (15) are the first known premyrsinane-type diterpenes that contain an acyl moiety instead of a keto group on C-14. Moreover, EFAL-19 (16) and EFAL-20 (17) are substituted with an ester group on C-2, which is also unprecedented.

On the basis of the diterpene composition, E. esula exhibits a chemotaxonomic relationship with E. salicifolia, as they contain the same main diterpene components, esulatin A, EUP-13 (10) and EUP-17 (11) and related compounds differing only in the esterification. E. esula can be characterized as displaying high morphological and chemical diversity.

All of the diterpenes were detected for the first time from the investigated plants. The chemical constituents of $E$. pannonica and E. falcata have not been investigated previously. 
The biological activities of most of the isolated compounds were investigated. Antiproliferative assays of some jatrophane (4, 5 and esulatins $A$ and $E)$, premyrsinane (12-15) and cyclomyrsinane (17) esters demonstrated strong activity against human tumour cells.

The compounds in the EUP and EFAL series were examined for their MDR-reversing activity and it was concluded that they enhance drug retention significantly in tumour cells by inhibiting the efflux pump activity. EUP-32 (5), EUP-29 (8), EFAL-4 (13), EFAL-6 (14), EFAL-7 (15), EFAL-19 (16) and EFAL-20 (17) exhibited much stronger effects than that of the positive control verapamil. Moreover, members of the EFAL series displayed a synergistic effect with doxorubicin. The ability of premyrsinane and cyclomyrsinane diterpenes to act as potent modulators of MDR has been evaluated here for the first time. Our results open up new opportunities in the design and development of drugs to overcome the MDR of human cancers. 


\section{References}

Mwine JT, Van Damme P. J. Med. Plant. Res. 2011; 5: 652-662.

Frodin DG. Taxon 2004; 53: 753-776.

Webster GL. Bot. J. Linn. Soc. 1987; 94: 3-46.

Király G. Új magyar füvészkönyv, Jósvafő: Aggteleki Nemzeti Park Igazgatóság, 2009. pp 268-272.

Hartwell JL. Lloydia 1969; 32: 153-205.

Hostettmann K, Lea PJ. Biologically active natural products, Oxford: Clarendon, 1987. pp 40-42.

Singla AK, Pathak K. Fitoterapia 1990; 61: 483-516.

8 Evans WC. Pharmacognosy, Edinburgh, London, New York, Philadelphia, St Luis, Sidney, Toronto: W.B. Saunders, 2002. p 27.

9 Schultes RE. Bot. J. Linn. Soc. 1987; 94: 79-95.

10 Liang QL, Dai CC, Jiang JH, Tang YP, Duan JA. Fitoterapia 2009; 80: 514-516.

11 G. Sánchez-Duffhues, M. Q. Vo, M. Pérez, M. A. Calzado, S. Moreno, G. Appendino, E. Muñoz. Curr Drug Targets. 2011; 12: 348-356.

Kissin I, Szallasi A. Curr. Top. Med. Chem. 2011; 11: 2159-2170.

Helmboldt H, Rehbein J, Hiersemann M. Tetrahedron Lett. 2004; 45: 289-292.

Forgo P, Kövér KE, Hohmann J. Monatsh. Chem. 2002; 133: 1249-1261.

Shizuri Y, Ohtsuka J, Kosemura S, Terada Y, Yamamura S. Tetrahedron Lett. 1984; 25: 5547-5550.

Manners GD, Davis DG. Phytochemistry 1987; 26: 727-730.

Miranda FJ, Alabadí JA, Ortí M, Centeno JM, Piñón M, Yuste A, Sanz-Cervera JF, Marco A, Alborch E. J. Pharm. Pharmacol. 1998; 50: 237-241.

Corea G, Fattorusso E, Lanzotti V, Megho P, Maffia P, Grassia G, lalenti A, lanaro A. J. Med. Chem. 2005; 48: 7055-7062.

Dang QL, Choi YH, Choi GJ, Jang KS, Park MS, Park NJ, Lim CH, Kim H, Ngoc LH, Kim JC. J. AsiaPacific Entomol. 2010; 13: 51-54.

Baloch IB, Baloch MK, Baloch AK. Planta Med. 2010; 76: 809-814.

Ahmad VU, Hussain H, Jassbi AR, Hussain J, Bukhari IA, Yasin A, Aziz N, Choudhary MI. J. Nat. Prod. 2003; 66: 1221-1224.

Hohmann J, Vasas A, Günther G, Máthé I, Evanics F, Dombi G, Jerkovich G. J. Nat. Prod. 1997; 60: 331-335.

Hohmann J, Evanics F, Vasas A, Dombi G, Jekovich G, Máthé I. J. Nat. Prod. 1999; 62: 176-178. Hohmann J, Vasas A, Günther G, Dombi G, Blazsó G, Falkay G, Máthé I, Jerkovich G.

Phytochemistry 1999; 51: 673-677.

Hohmann J, Evanics F, Berta L, Bartók T. Planta Med. 2000; 66: 291-294.

Hohmann J, Rédei D, Evanics F, Kálmán A, Argay G, Bartók T. Tetrahedron 2000; 56: 3619-3623. Hohmann J, Molnár J, Rédei D, Evanics F, Forgo P, Kálmán A, Argay G, Szabó P. J. Med. Chem. 2002; 45: 2425-2431.

Rédei D, Hohmann J, Evanics F, Forgo P, Szabó P, Máthé I. Helv. Chim. Acta 2003; 86: 280-289. Hohmann J, Evanics F, Dombi G, Molnár J, Szabó P. Tetrahedron 2001; 57: 211-215. Hohmann J, Evanics F, Dombi G, Szabó P. Tetrahedron Lett. 2001; 42: 6581-6584. Hohmann J, Rédei D, Forgo P, Molnár J, Dombi G, Zorig T. J. Nat. Prod. 2003; 66: 976-979. Hohmann J, Forgo P, Csupor D, Schlosser G. Helv. Chim. Acta 2003; 86: 3386-3393. Vasas A, Hohmann J, Forgo P, Szabó P. Tetrahedron 2004; 60: 5025-5030. Tutin TG, Heywood VH, Burges NA, Moore DM, Valentine DH, Walters SM, Webb DA. eds. Flora Europea, Vol 2. Cambridge: University Press, 1968. pp 211-220.

Simon T. A magyarországi flóra határozója, Harasztok - virágos növények, Budapest: Nemzeti Tankönyvkiadó 2000. pp 324-329.

Blaschek W, Hänsel R, Keller K, Reichling J, Rimpler H, Schneider G. Hagers Handbuch der Pharmazeutische Praxis, Vol. 2, Berlin, Heidelberg, New York: Springer, 1998. pp 619-666. Fattah A, Rizk M. Bot. J. Linn. Soc. 1987; 94: 293-326. 
Shi JG, Shi YP, Ji ZJ. Phytochemistry 1997; 45: 343-347.

Fattorusso E, Lanzotti V, Taglialatela-Scafati O, Tron GC, Appendino G. Eur. J. Org. Chem. 2002; 71-78.

Zhang W, Guo YW. Chem. Pharm. Bull. 2006; 54: 1037-1039. Warnaar F. Phytochemistry 1981; 20: 89-91.

Madureira AM, Gyémánt N, Ascenso JR, Abreu PM, Molnár J, Ferreira MJU. J. Nat. Prod. 2006; 69: 950-953.

Faure S, Connolly JD, Fakunle CO, Piva O. Tetrahedron 2000; 56: 9647-9653.

Liu X, Ye WC, Yu B, Zhao SX, Wu HM, Che CT. Carbohydr. Res. 2004; 339: 891-895.

Nishimura H, Wang LY, Kusano K, Kitanaka S. Chem. Pharm. Bull. 2005; 53: 305-308.

Su BN, Park EJ, Mbwambo ZH, Santarsiero BK, Mesecar AD, Fong HHS, Pezzuto JM, Kinghorn AD.

J. Nat. Prod. 2002; 65: 1278-1282.

Chatterjee A, Das B, Pascard C, Prange T. Phytochemistry 1981; 20: 2047-2048.

De Alvarenga MA, Gottlieb OR, Magalhaes MT. Phytochemistry 1976; 15: 844-845.

Rizk AM, Rimpler H, Ismail SI. Fitoterapia 1977; 48: 99-100.

Upadhyay RR, Hecker E. Phytochemistry 1974; 13: 752-753.

Schmidt RJ. Bot. J. Linn. Soc. 1987; 94: 221-230.

Bruneton J. Pharmacognosy, Phytochemistry, Medicinal Plants, Londres, Paris, New York:

Intercept, Technique \& Documentation, Lavoisier, 1999. pp 637-659.

Redei D. Isolation and structural characterization of new jatrophane diterpene polyesters from

Euphorbia serrulata and Euphorbia mongolica, PhD Thesis, 2005.

Vasas A. Isolation and Structural Elucidation of Diterpenes from Hungarian Euphorbia species, PhD Thesis, 2006.

Shi QW, Su XH, Kiyota H. Chem. Rev. 2008; 108: 4295-4327.

Duh CY, Wang SK, Tseng HK, Sheu JH, Chiang MY. J. Nat. Prod. 1998; 61: 844-847.

Rodríguez AD, Acosta AL. J. Nat. Prod. 1997; 60: 1134-1138

Rashid MA, Gustafson KR, Boyd MR. J. Nat. Prod. 2000; 63: 531-533.

Evans FJ, Taylor SE. Pro-inflammatory, tumour-promoting and antitumour diterpenes of the plant families Euphorbiaceae and Thymeleaceae. In: Herz W, Grisebach H, Kirby GW, eds.

Progress in the Chemistry of Organic Natural Products, Vol 44, Wien, New York: Springer, 1983. pp 1-99.

Kong LY, Li Y, Wu XL, Min ZD. Planta Med. 2002; 68: 248-252.

Xu ZH, Sun J, Xu RS, Qin GW. Phytochemistry 1998; 49: 149-151.

Choi YH, Kim J, Pezzuto JM, Kinghorn AD, Farnsworth NR. Tetrahedron Lett. 1986; 27: 57955798

Choi YH, Pezzuto JM, Kinghorn AD, Farnsworth NR. J. Nat. Prod. 1988; 51: 110-116.

El-Bassuony AA. Asian J. Chem. 2007; 6: 4553-4562.

Hegazy MEF, Mohamed AEHH, Aoki N, Ikeuchi T, Ohta E, Ohta S. Phytochemistry 2010; 71: 249253.

Duarte N, Lage H, Ferreira MJU. Planta Med. 2008; 74: 61-68.

Tao HW, Hao XJ, Liu PP, Zhu WM. Arch. Pharm. Res. 2008; 31: 1547-1551.

Geng D, Shi Y, Min ZD, Liang JY. Chin. Chem. Lett. 2010; 21: 73-75.

Guo J, Fang X, Di YT, Hua HM, Hao XJ. Chin. Chem. Lett. 2010; 21: 943-946.

Huang Y, Aisa HA. Phytochem. Lett. 2010; 3: 176-180.

Huang Y, Aisa HA. Helv. Chim. Acta 2010; 93: 1156-1161.

Shokoohinia Y, Chianese G, Zolfaghari B, Sajjadi SE, Appendino G, Taglialatela-Scafati O.

Fitoterapia 2011; 82: 317-322.

Song ZQ, Mu SZ, Di YT, Hao XJ. Chin. J. Nat. Med. 2010; 8: 81-83.

Aljancić IS, Pesić M, Milosavljević SM, Todorović NM, Jadranin M, Milosavljević G, Povrenović D, Banković J, Tanić N, Marković ID, Ruzdijić S, Vajs VE, Tesević VV. J. Nat. Prod. 2011; 74: 16131620. 
Weselowska O, Wisniewski J, Duarte N, Ferreira MJU, Michalak K. Ancicancer Res. 2007; 27 4127-4134. Duarte N, Járdánházy A, Molnár J, Hilgeroth A, Ferreira MJU. Bioorg. Med. Chem. 2008; 16: 9323-9330. Pesić M, Banković J, Aljancić IS, Todorović NM, Jadranin M, Vajs VE, Tesević VV, Vucković I, Momcilović M, Marković ID, Tanić N, Ruzdijić S. Food Chem. Toxicol. 2011; 49: 3165-3173. Molnár J, Gyémánt N, Tanaka M, Hohmann J, Bergmann-Leitner E, Molnár P, Deli J, Didiziapetris R, Ferreira MJU. Curr. Pharm. Des. 2006; 12: 287-311. Corea G, Di Pietro A, Dumontet C, Fattorusso E, Lanzotti V. Phytochem. Rev. 2009; 8: 431-447. Bedoya LM, Márquez N, Martínez N, Gutiérrez-Eisman S, Álvarez A, Calzado MA, Rojas JM, Appendino G, Munoz E, Alcami J. Biochem. Pharmacol. 2009; 77: 965-978. Barla A, Birman H, Kültür S, Öksüz S. Turk. J. Chem. 2006; 30: 325-332. Chang JS, Lee SW, Park MH, Kim MS, Hudson BI, Park SJ, Lee WS. Planta Med. 2010; 76: 1544 1549. Sahai R, Rastogi RP, Jakupovic J, Bohlmann F. Phytochemistry 1981; 20: 1665-1667. Marco JA, Sanz-Cervera JF, Yuste A, Jakupovic J. J. Nat. Prod. 1999; 62: 110-113. Duarte N, Varga A, Cherepnev G, Radics R, Molnar J, Ferreira MJU. Bioorg. Med. Chem. 2007; 15: 546-554. 
Vogg G, Achatz S, Kettrup A, Sandermann H Jr. J. Chromatogr. A 1999; 855: 563-573.

El-Mekkavy S, Meselhy MR, Nakamura N, Hattori M, Kawahata T, Otake T. Phytochemistry 2000; 53: 457-464.

El-Mekkavy S, Meselhy MR, Nakamura N, Hattori M, Kawahata T, Otake T. Chem. Pharm. Bull. 1999; 47: 1346-1347.

Baloch IB, Baloch MK, Saqib QN. Eur. J. Med. Chem. 2008; 43: 274-281.

Shokoohinia Y, Sajjadi SE, Zolfaghari B, Chianese G, Appendino G, Taglialatela-Scafati O. Fitoterapia 2010; 81: 884-890.

Wang HB, Chu WJ, Wang Y, Ji P, Wang YB, Yu Q, Qin GW. J. Asian Nat. Prod. Res. 2010; 12: 10381043.

Ghanadian M, Ayatollahi AM, Mesaik MA, Afsharypour S, Abdalla OM, Kobarfard F. Res. Pharm. Sci. 2011; 6: 35-41.

Forgo P, Rédei D, Hajdu Zs, Szabó P, Szabó L, Hohmann J. J. Nat. Prod. 2011; 74: 639-643.

Ayatollahi AM, Ghanadian M, Mesaik A, Abdella OM, Afsharypuor S, Kobarfard F, Mirza-taheri M. J. Asian Nat. Prod. Res. 2010; 12: 1020-1025.

Xu J, Jin D, Guoo Y, Xie C, Ma Y, Yamakuni T, Ohizumi Y. Bioorg. Med. Chem. Lett. 2012; 22: 3612-3618.

Jakupovic J, Jeske F, Morgenstern T, Tsichritzis F, Marco JA, Berendsohn W. Phytochemistry 1998; 47: 1583-1600.

Jakupovic J, Morgenstern T, Bittner M, Silva M. Phytochemistry 1998; 47: 1601-1609.

Abdelgaleil SAM, El-Aswad AF, Nakatani M. Pest. Manag. Sci. 2002; 58: 479-482.

Barile E, Fattorusso E, lalenti A, lanaro A, Lanzotti V. Bioorg. Med. Chem. 2007; 17: 4196-4200. Torrance SJ, Wiedhopf RM, Cole JR, Arora SK, Bates RB, Beavers WA, Cutler RS. J. Org. Chem. 1976; 41: 1855-1857.

Shi JG, Jia ZJ, Yang L. Phytochemistry 1993; 32: 208-210.

Shi JG, Jia ZJ. Phytochemistry 1995; 38: 1445-1447.

Roengsumran S, Petsom A, Kuptiyanuwat N, Vilaivan T, Ngamrojnavanich N, Chaichantipyuth C, Phuthong S, Phytochemistry 2001; 56: 103-107.

Vigor C, Fabre N, Fourasté I, Moulis C. Phytochemistry 2001; 57: 1209-1212.

Morgenstern T, Bittner M, Silva M, Aqueveque P, Jakupovic J. Phytochemistry 1996; 41: 11491153.

Haba H, Lavaud C, Magid AA, Benkhaled M. J. Nat. Prod. 2009; 72: 1258-1264.

Haba H, Lavaud C, Marcourt L, Long C, Harkat H, Benkhaled M. Biochem. Syst. Ecol. 2009; 37: 504-508.

Yu CC, Hsich CR, Hsiao G, Chen PY, Chang ML, Yin HW, Lee TH, Lee CK. Molecules 2012; 17: 2082-2090.

Yan S, Ye D, Wang Y, Zhao Y, Pu J, Du X, Luo L, Zhao Y. Rec. Nat. Prod. 2011; 5: 247-251.

Anjaneyulu ASR, Rao VL, Sreedhar K, J. Nat. Prod. 2002; 65: 382-385.

Qi-Cheng W, Ping TY, Wei DA, Qiang YF, Ao DJ. Chin. J. Nat. Med. 2010; 8: 101-103.

Geng ZF, Liu ZL, Wang CF, Liu QZ, Shen SM, Liu ZM, Du SS, Deng ZW. Molecules 2011; 16: 466476.

Ng AS, Phytochemistry 1990; 29: 662-664.

Shizuri Y, Kosemura S, Ohtsuka J, Terada Y, Yamamura S, Ohba S, Ito M, Saito Y. Tetrahedron Lett. 1984; 25: 1155-1158.

Li P, Feng ZX, Ye D, Huan W, Gang WD, Dong LX. Helv. Chim. Acta 2003; 86: 2525-2532.

Liu JH, Latif A, Ali M, Zhang GP, Xiang WJ, Ma L, Arfan M, Hu LH. Phytochemistry 2012; 75: 153158.

Uemura D, Hirata Y. Tetrahedron Lett. 1975; 16: 1701-1702.

Yamamura S, Kosemura S, Ohba S, Ito M, Saito Y. Tetrahedron Lett. 1981; 22: 5315-5318.

Kupchan SM, Uchida I, Branfman AR, Dailey RG Jr, Fei BY. Science, 1976; 191: 571-572.

Upadhyay RR, Bakhtavar F, Ghaisarzadeh M, Tilabi J. Tumori 1978; 64: 99-102.

Onwukaeme ND, Rowan MG. Phytochemistry 1992; 31: 3479-3482. 
Manners GD, Wong RY. J. Chem. Soc. Perkin Trans. I 1985; 2075-2081. Günther G, Hohmann J, Vasas A, Máthé I, Dombi G, Jerkovich G. Phytochemistry 1998; 47: 13091313.

Günther G, Martinek T, Dombi G, Hohmann J, Vasas A. Magn. Reson. Chem. 1999; 37: 365-370. Liu LG, Meng JC, Wu SX, Li XY, Zhao XC, Tan RX. Planta Med. 2002; 68: 244-248.

Manners GD, Davis DG. Phytochemistry 1984; 23: 1059-1062.

Starratt AN, Harris P. Phytochemistry 1971; 10: 1855-1856.

Lynn KR, Clevette-Radford NA. Phytochemistry 1986; 25: 1553-1557.

Aynehchi Y, Hakimzadeh MZQJ. Crude Drug Res. 1978; 16: 121-124.

Khamidova KA; Nazirov ZN. Khim. Prir. Soedin. 1972; 8: 112-113.

Abdulladzhanova NG, Mavlyanov SM, Dalimov DN. Chem. Nat. Comp. 2003; 39: 399-400.

Mouhajir F, Pedersen JA, Rejdali M, Towers GHN. Pharm. Biol. 2001; 39: 391-398.

Miyata S, Wang LY, Yoshida C, Kitanaka S. Bioorg. Med. Chem. 2006; 14: 2048-2051.

Yoshida C, Hishiyama K, Miyazaki K, Watanabe M, Kanbe M, Yamada Y, Matsuzaki K, Miyashita

K, Kitanaka S, Miyata S. Cancer Sci. 2010; 101: 374-378.

Luo H, Wang A. Can. J. Physiol. Pharmacol. 2006; 84: 959-965.

Wang JH, Zhou YJ, Bai X, He P. Mol. Cells 2011; 32: 451-457.

Wang Y, Ma X, Yan S, Shen S, Zhu H, Gu Y, Wang H, Qin G, Yu Q. Cancer Res. 2009; 69: 73027310.

Yan SS, Li Y, Wang Y, Shen SS, Gu Y, Wang HB, Qin GW, Yu Q. Mol. Cancer Ther. 2008; 7: 15231532.

Serova M, Ghoul A, Benhadji KA, Faivre S, Le Tourneau C, Cvitkovic E, Lokiec F, Lord J, Ogbourne SM, Calvo F, Raymond E. Mol. Cancer Ther. 2008; 7: 915-922.

Ogbourne SM, Hampson P, Lord JM, Parsons P, De Witte PA, SuhrbierA. Anticancer Drugs 2007; 18: 357-362.

Kedei N, Lundberg DJ, Toth A, Welburn P, Garfield SH, Blumberg PM. Cancer Res. 2004; 64: 3243-3255.

Ersvaer E, Kittang AO, Hampson P, Sand K, Gjertsen BT, Lord JM, Bruserud O. Toxins 2010; 2: 174-194.

Li J, Xu L, Wang FP. Helv. Chim. Acta 2010; 93: 746-752.

Pusztai R, Ferreira MJU, Duarte N, Engi H, Molnár J. Anticancer Res. 2007; 27: 201-206.

Lage H, Duarte N, Coburger C, HilgerothA, Ferreira MJU. Phytomedicine 2010; 17: 441-448.

Zhang JY, Mi YJ, Chen SP, Wang F, Liang YJ, Zheng LS, Shi CJ, Tao LY, Chen LM, Chen HB, Fu LW. J. Cell. Biochem. 2011; 112: 1076-1083.

Uto T, Qin GW, Morinaga O, Shoyama Y. Int. Immunopharmacol. 2011; 12: 101-109.

Ghosh S, Karin M. Cell 2002; 109: S81-96.

Wang LY, Wang NL, Yao XS, Miyata S, Kitanaka S. J. Nat. Prod. 2002; 65: 1246-1251.

Nunomura S, Kitanaka S, Ra C. Biol. Pharm. Bull. 2006; 29: 286-290.

Shu X, Yu L, Tang Y, Zhang L, DingA, Luo D, Duan J, Shen X. J. Nat. Med. 2010; 64: 98-130.

Zheng WF, Cui Z, Zhu Q. Planta Med. 1998; 64: 754-756.

Miyata S, Wang LY, Wang NL, Yao XS, Kitanaka S. Cell. Biol. Int. 2004; 28: 179-184.

Mucsi I, Molnár J, Hohmann J, Rédei D. Planta Med. 2001; 67: 672-674.

Valente C, Pedro M, Duarte A, Nascimento MS, Abreu PM, Ferreira MJU, J. Nat. Prod. 2004; 67: 902-904.

Engi H, Vasas A, Rédei D, Molnár J, Hohmann J, Anticancer Res. 2007; 27: 3454-3458.

Wu D, Sorg B, Hecker E. J. Nat. Prod. 1995; 58: 408-413.

Wang LY, Wang NL, Yao XS, Miyata S, Kitanaka S. Chem. Pharm. Bull. 2003; 51: 935-941.

Pan Q, Ip FCF, Ip NY, Zhu HX, Min ZD. J. Nat. Prod. 2004; 67: 1548-1551. 


\section{ACKNOWLEDGEMENTS}

I express my deepest gratitude to my supervisors, Prof. Dr. Judit Hohmann (present director of Department of Pharmacognosy), and Dr. Andrea Vasas, for the management of my work. I am greatly obliged to them for their never-failing professional guidance, humanity and encouragement, which have continually inspired me during my work.

I would like to thank Prof. Dr. Imre Máthé, former Director of the Department of Pharmacognosy, for the possibility and his strong support of my work.

Special thanks to Prof. Dr. Kálmán Szendrei and Dr. László Tóth for the numerous discussions and the inspiring me to work in an accurate way during my work.

I owe special thanks to Prof. Dr. József Molnár, Dr. Ana Martins for the MDR and to Dr. István Zupkó, Ágnes Berényi for antitumour activity experiments.

I am grateful to Dr. Tamás Rédei and Dr. Gyula Pinke for the collection and the identification of the plant material.

My thanks are likewise due to all my colleagues in the Department of Pharmacognosy for the favourable atmosphere. I am very grateful to all the staff members for their valuable help and support, namely to Erzsébet Berta for the excellent technical assistance. I would also like to thank my colleagues, Dr. Dóra Rédei, Dr. Katalin Veres and Dr. Dezső Csupor, who have always readily provided me with help, advice and reassurance.

I am also grateful to my colleagues in our laboratory, Dr. Botond Borcsa, Dr. Bence Csapi and Dr. Orsolya Roza, for the unique workplace atmosphere offered.

The half-year term financial support of Gedeon Richter Centenary Foundation is gratefully acknowledged.

I would like to extend my special thanks to my family for their support, encouragement and understanding attitude during these years. 


\section{APPENDIX}

The thesis is based on the following publications referred to in the text:

I. Sulyok E; Vasas A; Rédei D; Dombi G; Hohmann J.

Isolation and structure determination of new 4,12-dideoxyphorbol esters from Euphorbia pannonica Host.

Tetrahedron 2009; 65: 4013-4016.

II. Vasas A; Sulyok E; Rédei D; Forgo P; Szabó P; Zupkó I; Berényi A; Molnár J; Hohmann J. Jatrophane diterpenes from Euphorbia esula as antiproliferative agents and potent chemosensitizers to overcome multidrug resistance

J. Nat. Prod. 2011; 74: 1453-1461.

III. Sulyok E; Vasas A; Rédei D; Forgo P; Kele Z; Pinke G; Hohmann J. New premyrsinane-type diterpene polyesters from Euphorbia falcata Tetrahedron 2011; 67: 7289-7293.

IV. Vasas A; Sulyok E; Martins A; Rédei D; Forgo P; Kele Z; Zupkó I; Molnár J; Pinke G; Hohmann J. Cyclomyrsinane and premyrsinane diterpenes from Euphorbia falcata modulate resistance of cancer cells to doxorubicin Tetrahedron 2012; 68: 1280-1285. 